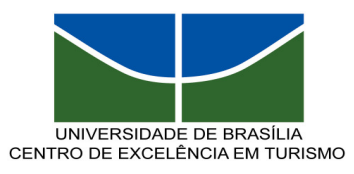

RICARDO AFONSO PEREIRA DE ARAÚJO

\title{
RELAÇÕES ENTRE O TEMA TRANSVERSAL MEIO AMBIENTE \\ E A QUESTÃO DA SUSTENTABILIDADE DO TURISMO APLICADA AO ENSINO FUNDAMENTAL DO DISTRITO FEDERAL
}




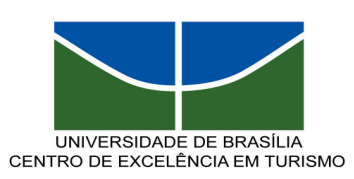

RICARDO AFONSO PEREIRA DE ARAÚJO

\section{RELAÇÕES ENTRE O TEMA TRANSVERSAL MEIO AMBIENTE E A QUESTÃO DA SUSTENTABILIDADE DO TURISMO APLICADA AO ENSINO FUNDAMENTAL DO DISTRITO FEDERAL}

Monografia apresentada ao Curso de Especialização em Formação de Professores na área de turismo da Universidade de Brasília - UnB como requisito parcial para obtenção do Título de especialista em Turismo.

Orientadora: Prfạ. Dóris Santos de Faria 
RICARDO AFONSO PEREIRA DE ARAÚJO

\section{RELAÇÕES ENTRE O TEMA TRANSVERSAL MEIO AMBIENTE \\ E A QUESTÃO DA SUSTENTABILIDADE DO TURISMO APLICADA AO ENSINO FUNDAMENTAL DO DISTRITO FEDERAL}

Prfa Dra Dóris Santos de Faria - Orientadora

Prof. Dr. Raul Luís de Melo Dusi - Membro da Banca

Aprovando em

Brasília, 2009 


\title{
AGRADECIMENTOS
}

\section{A Deus,}

acima de tudo.

Aos meus filhos,

pelo amor infinito.

\begin{abstract}
À Professora Dóris Santos de Faria, pelos ensinamentos fundamentais para 0 desenvolvimento do tema e da boa vontade e cortesia dispensadas durante a evolução do trabalho.
\end{abstract}

Obrigado a todos! 
Cada professor pode contribuir decisivamente ao conseguir explicitar os vínculos de sua área com as questões ambientais, por meio de uma forma própria de compreensão dessa temática, de exemplos abordados sobre a ótica de seu universo de conhecimentos e pelo apoio teóricoinstrumental de suas técnicas pedagógicas.

\section{Brasil,MEC/SEF/PCN's/MA, 1998}

Dormir e acordar, alimentar-se, ver as árvores florescerem e os pássaros se reproduzirem constituem vivências de todo ser humano. A experiência dos ciclos da vida é algo introjetado em qualquer indivíduo; resta-lhes a tomada de consciência desses ciclos e a reflexão sobre sua dinâmica de funcionamento.

\section{Brasil,MEC/SEF/PCN's/MA, 1998}

Viajar é mais que ir de um ponto a outro.

Viajar deve despertar paixões.

\section{Autor desconhecido}

Os estragos que nós seres humanos causamos à biosfera podem impedir nossa sobrevivência. Mesmo assim, os componentes físicos do planeta poderão persistir, pois certamente haverá possibilidade de microorganismos sobreviverem e se adaptarem às novas condições. Logo, o que se discute é a presença humana na terra - a consciência animal que "dá nome às coisas". Não é possível desconhecermos, viver sem nos darmos conta de que pertencemos à natureza de que dispomos, de que somos essa natureza.

\section{lara Brasileiro}




\section{RESUMO}

Nesta pesquisa propôs-se a revisão do estudo do meio ambiente e a sustentabilidade do turismo através da Educação Ambiental e sua aplicação no Ensino Fundamental como subtema do Tema Transversal Meio Ambiente dos Parâmetros Curriculares Nacionais, através da inserção de conteúdos nas Orientações Curriculares do Ensino Fundamental do Distrito Federal, para conhecimento do meio em que a criança vive. A metodologia adotada por este estudo foi a de análise dos estudos e documentos sobre o tema. Como resultado, foi sugerido, para as séries finais do nível fundamental, o estudo do bioma cerrado e as atividades de turismo cívico, ecoturismo e turismo rural voltadas à Brasília e aplicável às condições e interesses locais, de forma descentralizada, a partir das necessidades de cada localidade e tendo como metodologia as aulas de laboratórios, aulas práticas (de campo) e visitas técnicas; os passeios e excursões; a leitura em sala de aula; as pesquisas em grupo e individual; o uso de recursos audiovisuais e internet e os seminários e feiras. A expectativa é poder preparar os professores para formar cidadãos conscientes de que a exploração do turismo em qualquer região deve ser precedida de cuidados na preservação e no consumo sustentável dessas riquezas, sendo esse o único caminho para a preservação do homem em seu meio de vida.

Palavras-chave: Meio Ambiente. Sustentabilidade. Turismo. Ensino Fundamental 


\section{ABSTRACT}

In this research it was considered revision of the study of the environment and the support of the tourism through the Ambient Education and its application in Primary Education as subject of the Transversal Subject Environment of the National Curricular Parameters, through the insertion of contents in the Guidances Curricular of Primary Education of the Distrito Federal, for knowledge of the way where the child lives. The methodology adopted for this study was of analysis of the studies and documents on the subject. As result, it was suggested, for the final series of the basic level, the study of the bioma cerrado and the activities of civic tourism, ecotourism and agricultural tourism directed to applicable to the Brasilia and to the conditions and local interests, of decentralized form, from the necessities of each locality and having as methodology the practical lessons of laboratories, lessons (of field) and visits techniques; the strolls and excursions; the reading in classroom; the research in individual group and; the use of audio-visuais resources and internet and the seminaries and fairs. The expectation is to be able to prepare the professors to form conscientious citizens of whom the exploration of the tourism in any region must be preceded of cares in the preservation and the sustainable consumption of these wealth, being been this the only way for the preservation of the man in its half one of life.

Word-key: Environment. Support. Tourism. Basic education 


\section{LISTA DE FIGURAS}

Figura 1 Caminhada pelo cerrado - preservação da natureza.................. 18

Figura 2 Caminhada pelo cerrado - contato com a natureza.................... 19

Figura 3 Objetivos Gerais do Ensino Fundamental................................ 48

Figura 4 Biomas do Brasil......................................................... 61 


\section{LISTA DE ABREVIATURAS E SIGLAS}
APA
Área de Proteção Ambiental
Brasiliatur Empresa Brasiliense de Turismo
CECB Centro Educacional Católica de Brasília
CPDS Comissão de Políticas de Desenvolvimento Sustentável
EA Educação Ambiental
DF Distrito Federal
FunPEB Fundação Pólo Ecológico de Brasília
IBGE Instituo Brasileiro de Geografia e Estatística
IBRAM Instituto do Meio Ambiente e dos Recursos Hídricos do Distrito Federal
IDH Índice de Desenvolvimento Humano
LDB Lei de Diretrizes e Bases da Educação Nacional
MEC Ministério da Educação
OMS Organização Mundial da Saúde
OMT Organização Mundial do Trabalho
ONU Organização das Nações Unidas
PCN Parâmetro Curricular Nacional do Ministério da Educação
PNUD Programa das Nações Unidas para o Desenvolvimento
PNUMA Programa das Nações Unidas para o Meio Ambiente
RA Região Administrativa - Distrito Federal
RCNEI Referenciais Curriculares Nacionais para a Educação Infantil
SEBRAE Serviço de Apoio às Micro e Pequenas Empresas
SEDF Secretaria de Estado de Educação - Distrito Federal
SEDUMA Secretaria de Estado de Desenvolvimento Urbano e Meio Ambiente
SEMATEC Secretaria do Meio Ambiente e Tecnologia
SENAC Serviço Nacional de Aprendizagem Comercial
SIADE Sistema de Avaliação do Desempenho das Instituições Educacionais 


\section{SUMÁRIO}

1 Introdução Sobre o Tema do Trabalho e a Importância do Turismo....

2 Objetivos da Pesquisa

2.1 Objetivo Geral 15

2.2 Objetivos Específicos. 16

2.3 Possibilidades de Melhoria das Aulas

2.3.1 Laboratórios, Aulas Práticas de Campo e Visitas Técnicas. 17

2.3.2 Passeios e Excursões....................................................... 20

2.3.3 Leitura em Sala de Aula.................................................... 20

2.3.4 Pesquisas em Grupo e Individual........................................ 21

2.3.5 Uso de Recursos Audiovisuais e Internet............................. 21

2.3.6 Seminários e Feiras........................................................... 21

2.4 Relevância da Pesquisa................................................................ 22

3 Pressupostos Teóricos

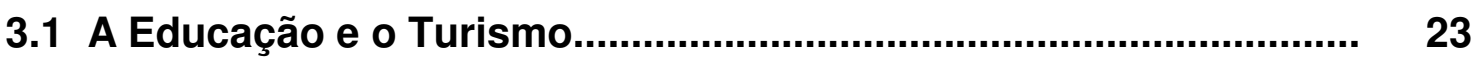

3.2 A Educação Ambiental................................................................ 25

3.3 A Agenda 21 e o Desenvolvimento Sustentável............................. 30

3.3.1 Agenda 21 Escolar................................................................... 34

3.4 Fundamentos Conceituais do Turismo e a Sustentabilidade......... 36

3.4.1 O Turismo Sustentável e o Ensino Fundamental no Brasil... $\quad 39$

3.5 A Lei de Diretrizes e Bases da Educação Nacional/LDB 9.394/96. 40

3.6 Os Parâmetros Curriculares Nacionais - PCN's............................ $\quad 42$

3.7 O Tema Transversal Meio Ambiente nos PCN's............................. 44

3.8 As Orientações Curriculares do Ensino Fundamental no DF........ 49

3.9 A Interrelação do Meio Ambiente, Educação Ambiental e o

Turismo Sustentável....................................................................... 56

3.10 As Características do Meio Ambiente e o Bioma Cerrado........... 60

3.10.1 0 Bioma Cerrado.................................................................... 61

3.11 O Turismo Sustentável no DF

3.11.1 A Política de Turismo no DF............................................... 64

3.11.2 O Potencial Turístico de Brasília......................................... 66

3.11.3 O Turismo Cívico em Brasília............................................. 66

3.11.3.1 - Principais Atrações Cívicas de Brasília............... 67 
3.11.4 O Ecoturismo em Brasília e Entorno.................................... 69

3.11.4.1 - Parques do Distrito Federal................................ 71

3.11.4.2 - Outras Atrações do Ecoturismo em Brasília...... 73

3.11.5 O Turismo Rural em Brasília e Entorno............................... $\quad \mathbf{7 4}$

4 Metodologia do Estudo.............................................................. 76

5 Resultado do Estudo................................................................... 77

5.1 Sugestões de Temas/Tópicos de Ensino - As Possibilidades da Inserção dos Conteúdos Relacionados ao Turismo nas Orientações Curriculares do Ensino Fundamental no DF (Séries e Anos Finais)..... 80

5.1.1 60 Ano / 5a Série................................................................... 81

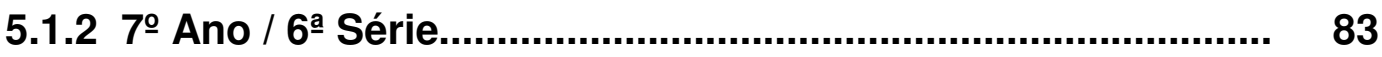

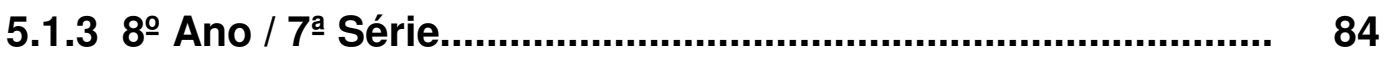

5.1.4 9 Ano / 8

6 Considerações Finais..................................................................... 88

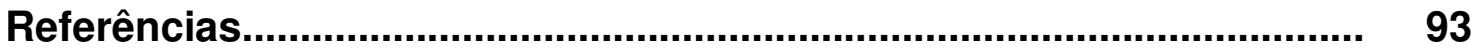




\section{INTRODUÇÃO SOBRE O TEMA DO TRABALHO E A IMPORTÂNCIA DO TURISMO.}

O estudo teórico das relações entre o meio ambiente e a sustentabilidade do turismo no Distrito Federal ganhou força a partir da observação de que esses temas são pouco discutidos nas salas de aulas do Ensino Fundamental de Brasília, séries e anos finais, pois são tratados de forma genérica e em menor abrangência do que merecem. Daí a vontade em debatê-los, objetivando chamar a atenção dos educadores que trabalham com as Orientações Curriculares do Ensino Fundamental do Distrito Federal, pois os Parâmetros Curriculares Nacionais do Ministério da Educação - PCN's e a LDB 9.396/96 - Lei das Diretrizes e Bases da Educação Nacional, permitem que os temas sejam inseridos e moldados nos currículos pela Secretaria de Educação local, mediante as necessidades das escolas públicas ou privadas das Regiões Administrativas - RA's. Tanto pode ser no Plano Piloto quanto nas Cidades Satélites, pois os seus conteúdos poderão ser ajustados de forma adequada às particularidades de cada comunidade.

Embora em um universo menor, tais desejos de contribuir para as transformações que deram-se em função das observações da vida de duas crianças estudantes do Ensino Fundamental de uma escola particular de Brasília/DF, como pai que sou e que monitora cuidadosamente o estudo dos filhos, não observei, nos livros didáticos das respectivas séries e tampouco nas outras atividades escolares, a merecida abrangência e aplicação de temas voltados à sustentabilidade ambiental e do turismo, voltados para o bioma cerrado e à Brasília.

Isso reforçou meu interesse pelo estudo teórico do tema transversal de Meio Ambiente e Educação Ambiental (EA), com perspectivas de promover a consciência, para os alunos das séries e anos finais do ensino fundamental, sobre a sustentabilidade ambiental, especialmente aplicada ao turismo, visando orientações para aplicação nas escolas no DF.

O ideal da proposta seria alcançar todo o universo de alunos da rede de ensino do Distrito Federal, nos diferentes níveis de ensino, sejam estudantes da rede pública ou privada, mas certamente há limitações para tal, inclusive porque nem todas as comunidades escolares têm vocações ou economias baseadas no turismo, ou mesmo seus membros tenham possibilidades de vivência com os turistas. 
Assim, em quaisquer dos tópicos aplicáveis ao tema transversal do meio ambiente, a EA deve ser estimulada. Para tal, serão feitas propostas de ações por meio da abordagem do "Turismo Sustentável" no Tema Transversal do "Meio Ambiente", de modo a atender as orientações e diretrizes para o Ensino Fundamental no DF. O desenvolvimento e a qualidade de vida melhoram quando as comunidades têm consciência sobre a importância da sustentabilidade para o meio em que vivem. Afinal, as crianças e os jovens são promotores fundamentais para as mudanças de comportamento das sociedades, sejam como cidadãos que recebem turistas ou como aqueles que fazem o turismo (turistas).

Nesse sentido, a monografia mostra a necessidade de discutir os aspectos relativos à sustentabilidade do meio em que a criança vive baseada nas premissas da Agenda 21, portanto, aplicável às condições e interesses das comunidades, através das Agendas (Local e das Escolas) e, quando for o caso, também a questão relativa à sustentabilidade do turismo, seja cívico, rural ou ecoturismo no cerrado.

Assim, o "Turismo Sustentável" poderia ser abordado nos currículos do ensino fundamental de Brasília, visando conscientizar os jovens sobre a necessidade de preservação das riquezas naturais do cerrado e as relações diretas com a sociedade e o seu desenvolvimento, além de colaborar para a melhoria do processo "ensino-aprendizagem" dos alunos nas temáticas relacionadas à área.

Pode ainda contribuir para o aperfeiçoamento da autonomia do professor na sua prática pedagógica, permitindo o desenvolvimento de um trabalho baseado em habilidades e competências a serem trabalhadas em função da realidade local de sua escola, contextualizando melhor o ensino.

Este estudo também poderá servir como instrumento complementar capaz de analisar o conteúdo programático curricular e o respectivo Tema Transversal de Meio Ambiente nas Orientações Curriculares, ao mostrar a necessidade de se preparar melhor a abordagem desses conteúdos programáticos e respectivas metodologias de ensino, para que sejam mais proveitosos. Também pode contribuir para que os professores fiquem mais capacitados para lidar com esses temas nas escolas. Poderá, até, colaborar para, além da necessidade de preparar mão-de-obra especializada no segmento, atender ao mercado local através da realização de novos projetos de preservação ambiental voltados para Brasília e regiões periféricas, principalmente devido ao seu acentuado crescimento demográfico e os reflexos na Capital da República. 
Além disso, o distanciamento entre as cidades e as diferenças culturais e sociais, pode ser melhor atendido com a possibilidade do ensino de diferentes temas que privilegiem as realidades locais. Assim, pode-se distribuir e abordar os aspectos relativos ao meio ambiente e sua sustentabilidade - por meio do turismo rural, ecoturismo ou turismo cívico - de acordo com as perspectivas de cada uma das localidades.

Como a atividade turística vem ganhando cada vez mais espaço na sociedade, tornou-se uma das principais formas de lazer na vida moderna, cada vez mais accessível às classes mais baixas, de modo que a oferta turística tem se segmentado, procurando atender a todos os tipos de pessoas. Todavia, o planejamento para realizar estas atividades acaba deixando para segundo plano a preocupação com a população e o meio ambiente, até mesmo com a cultura local, mostrando que, se o turismo apenas privilegiar os turistas, as particularidades da localidade que formam os atrativos turísticos permanecerão desassistidas, ou mesmo deixando importantes características desconhecidas dos turistas.

"O turista tenta recuperar a arte de viver, tenta dar sentido poético à vida. As pessoas deveriam viajar como se fugissem de casa. $O$ turista tenta dar sentido poético à vida. E, pelos instantes que dura, dá certa sensação de felicidade, de sentido. É isso que o turista persegue: quer sentir o tempo vibrar, livre da escravidão da rotina diária." (França, 2006, pág. 9)

Finalizando é sobre a busca do inusitado que o planejamento turístico precisa investir, levando em consideração a participação da população nativa, a fim de prevenir distorções e permitir que um número maior de pessoas possa participar de forma ativa, beneficiando-se da atividade turística desenvolvida na localidade, já que, atualmente, essa população tem participação ínfima no planejamento e execução do plano turístico. 


\section{OBJETIVOS DA PESQUISA}

\section{1 - Objetivo Geral}

Os fundamentos apontam para uma nova realidade do mundo, onde os reflexos do consumo imensurável passam a ser fator de desequilíbrio em virtude do abusivo desgaste das riquezas naturais do Planeta. É possível perceber que a ação destrutiva, oriunda de qualquer parte, tem reflexo em todos os outros lugares, sejam em países pobres ou ricos, embora a humanidade esteja mais consciente das ameaças que pesam sobre o ambiente natural, passando a buscar soluções para a manutenção e valorização dessas riquezas.

Aprender a conhecer, a conviver com os outros e a ser um melhor cidadão são comportamentos a serem desenvolvidos na criança e no adolescente pela família e tarefas complementares do professor, seja em sala de aula ou em outro ambiente apropriado. A escola deve preparar os alunos tornando-os hábeis, Ihes permitindo a tomarem decisões. Por outro lado, faz-se necessário aprender também, desde criança, a receber o turista em sua região ou a ser turista em outras regiões, demonstrando conhecimento sobre a preservação e o uso sustentável do meio ambiente que está inserido. A palavra é do professor e a aprendizagem não poderá ser mecânica, mas através de um processo interativo entre ele e os seus alunos.

Assim, a política nacional de meio ambiente, tornou obrigatória a adoção, em todos os níveis de ensino, dos estudos sobre a EA, de modo a contemplar a compreensão de cidadania e posicionamento crítico sobre as características fundamentais, dimensões e valorização sociocultural da região, objetivando melhoria do meio ambiente e da qualidade de vida da população envolvida.

$\mathrm{Na}$ realidade, esses temas ainda não foram muito bem desenvolvidos pelas instituições de ensino, pois vêm sendo estudados de modo preliminar, informativo e livresco, principalmente em relação à EA e ao turismo sustentável no bioma cerrado, que é pouco tratado de maneira transversal no ensino fundamental do DF.

Sendo assim e amparado no que dispõem a LDB no 9.394/96 e os PCN's, o principal objetivo da pesquisa é inserir, no Tema Transversal Meio Ambiente, o subtema da Sustentabilidade do Turismo no Distrito Federal, para as séries e anos finais - Ciências Naturais (Vida e Ambiente) das Orientações Curriculares do Ensino Fundamental local, com as melhores práticas e métodos de sugestões pedagógicas 
e tópicos de ensino, visando aumentar as habilidades e o grau de conhecimento e de cultura dos jovens estudantes, seja em sala de aula ou em outro ambiente apropriado, pois é fato que estes assuntos são pouco explorados pelas escolas públicas e particulares das cidades que compõem as respectivas RA's (Regiões Administrativas).

\section{2 - Objetivos Específicos}

$\rightarrow$ Sugerir temas de ensino da Educação Ambiental e do meio ambiente (biodiversidade, clima e bioma), sustentabilidade ambiental (conceitos, formação ética e qualidade de vida) e do turismo (conceitos, patrimônio sócio cultural e localização geográfica) e relacioná-los ao Distrito Federal, tendo como instrumento as Orientações Curriculares e os professores das escolas públicas e privadas das Regiões Administrativas locais;

$\rightarrow$ Preparar conteúdos voltados para a educação ambiental, o turismo e o turismo sustentável apresentando suas inter-relações, visando uma melhor formação da consciência e importância da preservação da qualidade do meio ambiente e a sustentabilidade da atividade turística, do turismo rural e do ecoturismo no DF.

$\rightarrow$ Utilizar técnicas e ferramentas práticas e atuais que despertem nos jovens 0 interesse na pesquisa e no cuidado ao meio ambiente. Afinal, é preocupante a sensação de que, se não cuidarmos hoje, as futuras gerações não terão oportunidade em conhecer e fazer turismo em uma das mais belas regiões do Planeta - o cerrado, que está sendo destruído e consumido devido a interesses e justificativas inaceitáveis de desenvolvimento populacional desordenado e ocupação criminosa dos espaços naturais para o cultivo de lavouras ou pastagens para animais.

Para tal, de acordo com o que rezam as Orientações Curriculares do Ensino Fundamental da Secretaria de Educação do GDF - (2009 pág's 107 e 108), renderse às novas concepções é sempre uma situação negociada, que exige a participação ativa dos alunos. Um processo que exige a mediação competente, atenta e comprometida do professor, quando se quer assegurar que se estabeleça nas salas de aula um processo de construção e apropriação de saberes científicos. Segundo esta perspectiva, num processo genuíno de ensino e aprendizagem de Ciências, espera-se que os professores apóiem seus alunos a: 
- "Investigar fenômenos e explorar idéias, o que é bastante diferente de lidar com conteúdos selecionados do corpo de conhecimentos de Física, Química ou Biologia, sem a necessária articulação com a realidade à qual se referem";

- "Formular perguntas sobre fenômenos e processos observados - e não responder questionários exaustivos ou a perguntas de roteiros de pesquisa de campo, de protocolos de experimentação"; e

- "Dar respostas para perguntas que eles mesmos se fazem, em relação ao mundo natural e ao mundo da tecnologia." (2009 pág. 108).

\section{3 - Possibilidades de Melhoria das Aulas}

Há métodos e técnicas existentes mais indicadas para os professores, visando atender aos objetivos relacionados ao estudo, como os seguintes:

\subsection{1 - Laboratórios, Aulas Práticas (de Campo) e Visitas Técnicas}

Bizerril (2001) relata que, embora a rede de ensino pública do Distrito Federal seja carente de investimentos, há dados que demonstram que os alunos gostam desse tipo de aula e se sentem motivados quando a mesma é proposta e, desse modo, o desenvolvimento dessas aulas pode ser uma importante ferramenta no ensino para os alunos, principalmente levando-se em consideração que os temas são essencialmente voltados para a conservação da natureza.

As aulas práticas podem ajudar no desenvolvimento de conceitos científicos, além de permitir que os estudantes aprendam como abordar objetivamente o seu mundo e como desenvolver soluções para problemas complexos (Lunetta, 1991), citado por Bizerril (2001). Além disso, as aulas práticas servem de estratégia e podem auxiliar o professor a retomar um assunto já abordado, construindo com seus alunos uma nova visão sobre um mesmo tema.

Assim, os alunos, quando compreendem um conteúdo trabalhado em sala de aula, ampliam suas reflexões sobre os fenômenos que acontecem em torno deles e isso pode gerar, conseqüentemente, discussões durante as aulas fazendo com que explorem suas idéias e aprendam a respeitar as opiniões de seus colegas de sala (Lunetta 1991), citado por Bizerril (2001). Hodson (1998), também citado por Bizerril (2001) afirma que as atividades práticas também podem ser feitas através de trabalhos de campo, computadores e estudos em museus. 
Já Borges (2002), afirma que na aula prática "o importante não é a manipulação de objetos e artefatos concretos, e sim o envolvimento comprometido com respostas/soluções bem articuladas para as questões colocadas, em atividades que podem ser puramente de pensamento".

Desta forma, as aulas práticas e de laboratórios podem ser facilmente conectadas às ciências naturais, especificamente para os estudos ligados ao turismo sustentável (meio ambiente, turismo e sustentabilidade).

Nesse sentido, artigo recente de um Jornal semanário de Brasília1 intitulado: "Aprendendo a ser humano" aponta que: "Escolas desenvolvem atividades extracurriculares que promovem a cidadania, a solidariedade, o respeito às diferenças e o amor à natureza. Com isso, os alunos se tornam mais conscientes e interessados no estudo". (pág 5)

A matéria informa que, atualmente, algumas escolas do Distrito Federal desenvolvem atividades para ensinar aos alunos assuntos relacionados à cidadania, solidariedade e, principalmente, o respeito à natureza.

Com isso, estudantes de todas as idades começam desde cedo a praticar, na teoria e na prática, esses assuntos tão importantes e que ajudam bastante no aprendizado.

O documento aponta que a escola Leonardo da Vinci desenvolve desde 2002 o projeto chamado Ecotrilhas do Brasil. O objetivo é desenvolver nos alunos a solidariedade, o respeito às diferenças, a superação de limites e a convivência em grupo com um foco comum. Os alunos aprendem, em uma oficina teórica, noções de ecoturismo, desenvolvimento sustentável, educação ambiental e noções sobre os equipamentos e procedimentos de segurança. Depois, eles fazem caminhadas em áreas de campo com características similares às estudadas.

Figura 1

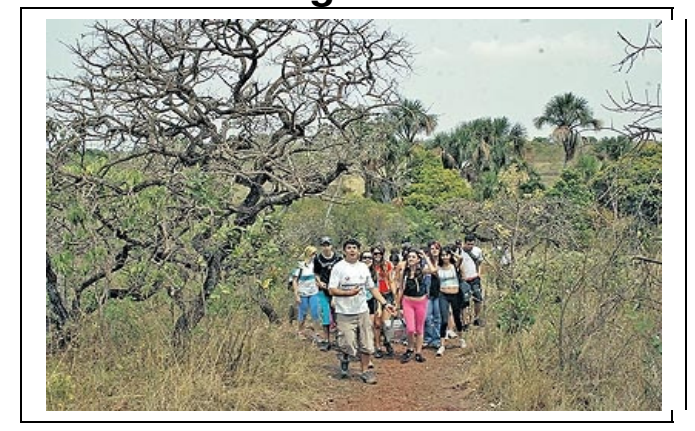

Fonte: Jornal da Comunidade - Edição 1063 - 11/04 a 17/04 de 2009

1 - Jornal da Comunidade - Edição 1063 - 11/04 a 17/04 de 2009 - pag. 5 
A Figura 1 registra a caminhada dos alunos da Escola Leonardo Da Vinci (Brasília) pelo cerrado aonde os alunos aprendem a respeitar a natureza e a entender a importância de preservar o meio ambiente em favor da vida (Jornal da Comunidade, op.cit.).

A matéria diz ainda que, na $7^{\circ}$ série, os alunos acampam para se identificarem com o meio ambiente. Posteriormente, na $8^{\underline{a}}$ série, realiza-se uma viagem a um ambiente natural e, finalmente, eles fazem acampamentos, técnicas verticais, entradas em cavernas e a esperada viagem para o Pico da Bandeira.

Esse projeto é desenvolvido e operado como se fosse um centro de treinamento, com orientação da Cruz Vermelha, SENAC, bombeiros e adaptado à realidade da escola para operar com os alunos. O coordenador disciplinar da escola, Luciano Gallo, afirma que "o ambiente natural desenvolve o lado humano dos alunos. A natureza é um suporte para atingir todos esses ensinamentos, além de desenvolvermos uma produção do ecoturismo no país”.'(pág 5)

O trabalho traz outro exemplo - o Centro Educacional Católica de Brasília (CECB) que também desenvolve essas saídas pedagógicas que reforçam o aprendizado de sala de aula, e ainda une teoria e prática. Vicente de Paulo Crivellaro, professor de biologia e coordenador dos laboratórios, afirma que "por mais que o aluno trabalhe em sala, ele precisa estar no ambiente. Uma teoria estudada em sala vale mais quando unida a uma saída. Agente observa que até a mente deles se abre independentemente da idade”.(pág 5)

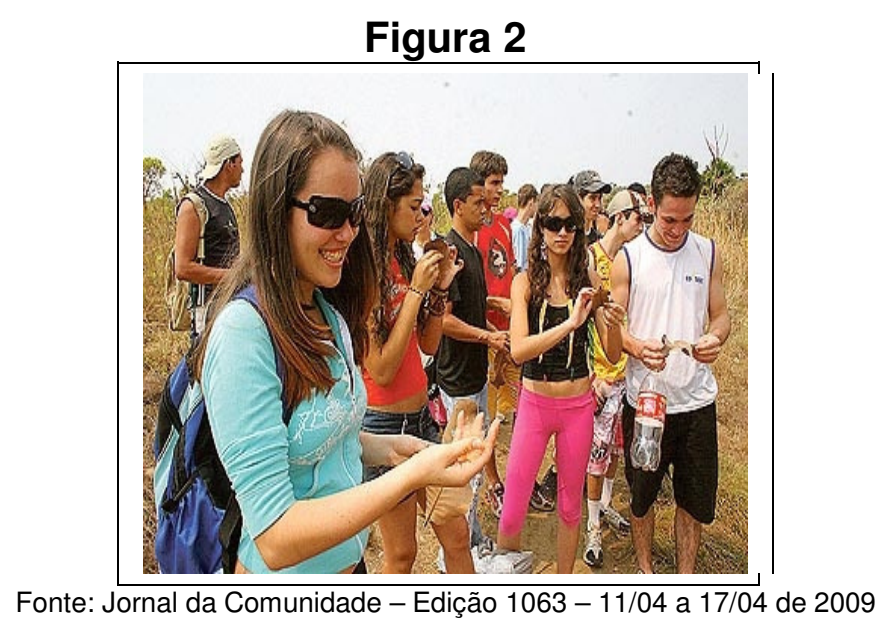

A Figura 2 apresenta a caminhada dos alunos da Escola Leonardo Da Vinci (Brasília) pelo cerrado Os alunos também se tornam mais solidários no contato com a natureza.

"Os locais visitados têm rumo. São aulas práticas no laboratório para depois visitar o ambiente. Os alunos saem aos arredores da escola vendo textura de caule, folhas, liquens, formigueiros e ainda focam temas como fauna, flora, clima e solo do cerrado, além de observar os impactos causados pelo homem e aprender como prevenir possíveis queimadas." (Jornal da Comunidade, Crivellaro, 2009, pág 5) 
Assim, em virtude da natureza dos temas, esse tipo de atividade é de extrema importância, pois o aprendizado é muito mais eficiente, já que aproxima os alunos pela prática e exercício, facilitando a memorização, porém não devem ser atividades meramente recreativas ou eventuais, embora seja admissível as dificuldades das escolas pela falta de recursos em logística e deslocamentos e aparelhagem. Estas atividades associadas a locais turísticos certamente atendem aos objetivos de desenvolver nos alunos atitudes ambientalmente mais corretas e adequadas a um turismo sustentável, conforme prevê os temas transversais do meio ambiente e sua disciplinaridade.

\subsection{2 - Passeios e Excursões}

Diferentemente do "trabalho de campo" que é um instrumento que tende a associar teoria e prática, os passeios e excursões são atividades relativamente mais recreativas e de socialização dos alunos em função da possibilidade de sair da rotina escolar de sala de aula, embora sejam também instrumentos didáticos importantes no ensino, tendo em vista as variadas opções dessas atividades no Distrito Federal, sejam para o turismo cívico (Palácios, museus e templos), o ecoturismo (cachoeiras, chapadas, grutas, cavernas, parques e reservas ecológicas) e o turismo rural (hotéis fazendas entre outros).

\subsection{3 - Leitura em Sala de Aula}

A leitura é uma habilidade a ser adquirida desde cedo e treinada em várias formas. Lê-se para entender e conhecer, para sonhar, viajar na imaginação, por prazer ou curiosidade. A leitura é fundamental no desenvolvimento do ser humano e a escola possui um papel importante no desenvolvimento do hábito de ler, apesar das dificuldades encontradas com os acervos disponíveis. Normalmente, os assuntos ligados ao meio ambiente, à sustentabilidade, à natureza e ao cerrado de um modo geral despertam interesse nos alunos do ensino fundamental, mas cabe aos professores a tarefa da monitoração e acompanhamento visando estabelecer um vínculo maior entre esses temas e o turismo, devendo buscar sempre temas interessantes, de tal forma que a leitura seja dinâmica, objetiva e atenda aos requisitos do Tema Transversal do PCN Meio Ambiente. 


\subsection{4 - Pesquisas em Grupo e Individual}

A pesquisa deve ser desenvolvida em sala de aula como princípio educativo e precisa ser vista, entendida e praticada como instrumento para construir novos conhecimentos, através da manifestação do pensamento dos alunos e do diálogo oral ou escrito, que formam sucessivamente o questionamento, o desenvolvimento e o aprendizado dos alunos.

Nesse sentido, atualmente há extenso campo de pesquisa para os assuntos relacionados à sustentabilidade, mas que não vem sendo explorados pelos professores, fato que contribui para o baixo interesse dos alunos.

\subsection{5 - Uso de Recursos Audiovisuais e Internet}

Embora a Internet seja um recurso com potencial para determinadas atividades educativas, ela reduz a presença do professor, mas amplia o alcance do das idéias, com todos os fatores associados ao formato hipertexto, à velocidade e às multi-representações. Nesta ótica, é inevitável que coloquemos tais máquinas nas mãos de nossas crianças e adolescentes, porém sempre predominando o ato de educar, de examinar e monitorar criticamente aquilo que está lá. Atualmente, já é possível fazer turismo virtual, embora essa modalidade nunca vá substituir a emoção e o prazer daquele turista que prefere explorar e conferir pessoalmente as riquezas naturais de uma região, desde que seja de forma sustentável.

\subsection{6 - Seminários e Feiras}

Os seminários e as feiras contribuem para completar a função da escola na sua missão de difundir e proporcionar aos indivíduos a possibilidade de se apropriar de uma cultura tecnológica e científica, constituindo-se um ambiente de aprendizagem não-formal.

Essas contribuições originam-se do fato de que os organizadores desses eventos levam em consideração os interesses imediatos do público que os visitam, não centraliza em disciplinas formais, mantém a liberdade quanto aos fundamentos, natureza e intenções das mensagens e não há avaliação formalizada e sim a preocupação em relação às motivações pessoais do público e sua promoção e ascensão social. 
Os Ambientes não-formais de aprendizagem apresentam alternativas a serem exploradas com vistas à melhoria do processo ensino-aprendizagem. A potencialidade das feiras que envolvem globalidade, complexidade e transdisciplinaridade, constitui-se num universo para a educação formal.

A organização de seminários e feiras traz em seu bojo a intenção de divulgar e ampliar os conhecimentos dos alunos num tema específico, cuja riqueza de argumentos para o seu meio ambiente e para o turismo de um modo geral é de grande importância para a sua sustentabilidade.

Desse modo, podemos destacar em Brasília a realização de feiras relacionadas à agropecuária (rodeios, leilões e competições), a Embrapa (produtos e gêneros alimentícios relacionados ao cerrado, com o desenvolvimento sustentável e tecnologia de ponta na reprodução e combate às pragas nas lavouras), a Festa dos Estados (produtos e folclore de vários estados tradicionais do País) e as feiras de tecnologia das Instituições de Ensino, sejam públicos ou privados.

\section{4 - Relevância da Pesquisa}

A relevância deste estudo é demonstrar que, com o apoio dos professores nas novas atividades escolares para o Ensino Fundamental que são voltadas às relações entre o Tema Transversal Meio Ambiente e a questão da sustentabilidade do turismo, haverá sensível melhoria na qualidade de vida das comunidades receptoras do turismo no DF por meio da manutenção das riquezas naturais do cerrado e cívicas da cidade, dada a viabilidade dessas aplicações pedagógicas asseguradas pela LDB no 3.934/96, que permite a inserção de temas regionais, neste caso voltados ao turismo sustentável e ao meio ambiente, em conformidade com as necessidades e características de cada localidade. 


\section{PRESSUPOSTOS TEÓRICOS}

\section{1 - A Educação e o Turismo}

A educação está na pauta das discussões mundiais. Em diferentes lugares do mundo discute-se cada vez mais o papel essencial que ela desempenha no desenvolvimento das pessoas e das sociedades. Documentos de órgãos internacionais apresentam reflexões sobre a educação e fazem uma análise prospectiva em que destacam alguns aspectos.

Num contexto mundial, marcado pela interdependência crescente entre os povos, pressupõe-se que é preciso aprendemos a viver juntos no planeta. Mas como fazê-lo se não formos capazes de viver em nossas comunidades naturais de pertinência: nação, região, cidade, bairro, participando da vida em comunidade?

Por outro lado, a necessidade de que a educação trabalhe a formação ética dos alunos está cada vez mais evidente. A escola deve assumir-se como um espaço de vivência e de discussão dos referenciais éticos, não uma instância normativa e normatizadora, mas um local social privilegiado de construção dos significados éticos necessários e constitutivos de toda e qualquer ação de cidadania, promovendo discussões sobre a dignidade do ser humano, igualdade de direitos, recusa categórica de formas de discriminação, importância da solidariedade e observância das leis. Para tal, além da análise da conjuntura mundial, a escola deverá seguir as seguintes recomendações quanto ao seu papel buscando uma verdadeira construção da cidadania dos jovens:

- as políticas educacionais devem ser suficientemente diversificadas e concebidas, de modo a que a educação não seja um fator suplementar da exclusão social;

- os tempos e os campos da educação devem ser repensados, completar-se e interpenetrar-se, de modo que, cada indivíduo, ao longo de sua vida, possa tirar o melhor proveito de um ambiente educativo em constante transformação;

- a educação deve estar fundamentada em quatro pilares: aprender a conhecer, que pressupõe saber selecionar, acessar e integrar os elementos de uma cultura geral, suficientemente extensa e básica, com o trabalho em profundidade de alguns assuntos, com espírito investigativo e visão crítica. Em resumo, significa ser capaz de aprender a aprender ao longo de toda a vida; aprender a fazer, que pressupõe desenvolver a competência do saber se relacionar em grupo, saber resolver 
problemas e adquirir uma qualificação profissional; aprender a viver com os outros, que consiste em desenvolver a compreensão do outro e a percepção das interdependências, na realização de projetos comuns, preparando-se para gerir conflitos, fortalecendo sua identidade e respeitando a dos outros, respeitando valores de pluralismo, de compreensão mútua e de busca da paz; e aprender a ser, para melhor desenvolver sua personalidade e poder agir com autonomia, expressando opiniões e assumindo as responsabilidades pessoais.

Já a Declaração Mundial sobre a Educação para Todo2 destaca, em um dos seus artigos, que toda pessoa - criança, adolescente ou adulto - deve poder se beneficiar de uma formação concebida para responder às suas necessidades educativas fundamentais.

Essas necessidades compreendem tanto os instrumentos de aprendizagem essenciais (leitura, escrita, expressão oral, cálculo, resolução de problemas) como conteúdos educativos (conceitos, atitudes, valores), dos quais o ser humano tem necessidade para viver e trabalhar com dignidade, participar plenamente do desenvolvimento, melhorar a qualidade de sua existência, tomar decisões de forma esclarecida e continuar a aprender.

A comunidade deve ser incentivada a resgatar suas raízes, o que possibilita maior articulação entre seus membros para que mostrem sua identidade cultural aos turistas. Isto é uma forma de melhorar o acesso da população a seus próprios bens materiais e imateriais, colaborando para sua perpetuação entre as gerações e um conhecimento mais profundo deles.

Daí ser fundamental que os jovens, desde o início de sua formação, sejam preparados para conviver não só entre si e sua comunidade, mas também com os visitantes na localidade ou serem visitantes em outros ambientes. E, se a localidade em que vivem, for um local de turismo, aprendam a conviver com esta realidade de modo sustentável, como também devem estar preparados para receber os indivíduos que passam a frequentar estes locais.

Para tal, a escola é o melhor canal de ligação entre a educação e seus alunos, pois as ações de valorização das culturas locais proporcionam aos turistas um olhar diferente, que remete a indagações e mais adiante à compreensão do que está sendo visitado. 
É imprescindível que os turistas tenham uma relação mais profunda com a comunidade, para que possam conhecer e respeitar a cultura da população local e até mesmo compreender melhor a sua identidade, a partir das semelhanças e diferenças existentes entre as culturas do viajante e do nativo, pois, através do turismo, pode-se também sensibilizar a sociedade para a importância deste como instrumento de desenvolvimento econômico como meio de geração de empregos, fator fundamental na dinâmica da economia local.

A partir das considerações anteriores pode-se concluir que a atividade turística pode contribuir para a divulgação das culturas locais, ajudando na formação pessoal e cidadã de seus membros, além de criar um senso ético sobre as ações pessoais, visto que as pessoas lutarão por um desenvolvimento sustentável a fim de manterem e fortalecerem sua identidade e herança cultural através das futuras gerações, daí vir a ser fundamental o envolvimento das crianças e dos jovens, portanto, o envolvimento da escola.

Assim, buscar inserir o tema do turismo no ensino escolar, a começar pelo nível fundamental, é essencial para garantir o alcance de todos esses requisitos, pois a educação para o turismo, dentro dos princípios da sustentabilidade ambiental, mostra-se de extrema valia para o próprio desenvolvimento sustentável das comunidades, envolvendo aspectos econômicos, ecológicos, sociais e educacionais, ou seja, a sustentabilidade ambiental lato sensu, afinal o meio ambiente é tudo isso e os jovens deverão aprender a comportarem-se como visitantes ou turistas de modo a contribuírem para a sustentabilidade dos locais que convivem, seja como visitantes, turistas ou receptores de turismo e a educação ambiental é o melhor caminho para alcançar esses objetivos.

\section{2 - A Educação Ambiental}

Diz a Carta Magna Brasileira que: "todos tem direito ao meio ambiente ecologicamente equilibrado, bem de uso comum do povo e essencial à sadia qualidade de vida, impondo-se ao poder público e à coletividade o dever de defendêlo e preservá-lo para as presentes e futuras geracões" e que imcumbe a esse poder: "promover a educação ambiental em todos os níveis de ensino e a conscientização pública para a preservação do meio ambiente." (Constituição Federal, art. 225, Caput e $\left.\S 1^{\circ}, \mathrm{VI}\right)$. 
De acordo com a Lei n 9.795/99 da Política Nacional de Educação Ambiental, entende-se por Educação Ambiental os processos por meio dos quais o indivíduo e a coletividade constroem valores sociais, conhecimentos, habilidades, atitudes e competências voltadas para a conservação do meio ambiente, bem de uso comum do povo, essencial à sadia qualidade de vida e sua sustentabilidade. Seus princípios fundamentais são:

- enfoque humanista, holístico, democrático e participativo;

- concepção do meio ambiente em sua totalidade, considerando a interdependência entre o meio natural, o sócio-econômico e o cultural, sob o enfoque da sustentabilidade;

- pluralismo de idéias e concepções pedagógicas, na perspectiva da inter, multi e transdisciplinaridade;

- vinculação entre a ética, a educação, o trabalho e as práticas sociais;

- garantia de continuidade e permanência do processo educativo;

- permanente avaliação crítica do processo educativo;

- abordagem articulada das questões ambientais locais, regionais, nacionais e globais;

- reconhecimento e o respeito à pluralidade e à diversidade individual e cultural.

Faria (1997) ressalta que a Política Nacional de Meio Ambiente (Lei no 6.398 de 31/01/81), determina que a Educação Ambiental (EA) seja adotada em todos os níveis de ensino, embora como caráter interdisciplinar e, por isso mesmo, não deve ser constituída como uma disciplina específica, segundo o Conselho Federal de Educação (Parecer no 226/87), que também recomenda às universidades a preparação dos docentes para o ensino da EA no ensino fundamental, tendo conseqüências diretas sobre as redes escolares municipal e estadual, embora a abordagem que vem sendo realizada - quase que exclusivamente informativa e conservacionista restrita a conteúdos de ecologia - apresente pouca ou nenhuma inter-relação com a experiência dos indivíduos, das comunidades e dos processos de desenvolvimento inadequados à preservação do meio ambiente.

Ainda de acordo com aquela autora (Faria, 1997), o ensino de ciências também vem sendo desenvolvido de modo puramente informativo, livresco, detalhista, desconectado da realidade e dos interesses dos alunos, exigindo, destes, processos mentais predominantemente de memorização simples e não propicia compreensão dos fenômenos estudados. Estes parecem não ter relação entre si e 
pouco é mostrado da sua inserção na vida do jovem estudante, deixando a disciplina muito pouco interessante para o aluno, assim como para o professor.

Então para Faria (1997), a Educação Ambiental deveria desenvolver hábitos, atitudes e comportamentos que propiciassem a formação de uma cultura eminentemente ativa na defesa de um meio ambiente saudável e do uso racional dos recursos naturais não-renováveis, cujas comunidades locais teriam a capacidade de repensar seu processo de desenvolvimento, corrigindo distorções e propondo inovações que garantam o desenvolvimento, sem comprometer, irremediavelmente, as condições ambientais. Como exemplo, na Região Centro Oeste deveria ser privilegiado o estudo sobre a conservação do bioma do Cerrado e as atitudes dos estudantes em relação à percepção ambiental da região, pois se existem diferenças sociais e culturais marcantes, que determinam diferentes necessidades de aprendizagem, existe também aquilo que é comum a todos, que um aluno de qualquer lugar do Brasil, de uma grande cidade ou da zona rural, deve ter o direito de aprender e esse direito será garantido pelo Estado. Esses referenciais buscam orientar e garantir a coerência das políticas de melhoria da qualidade de ensino, socializando discussões, pesquisas e recomendações, subsidiando a participação de técnicos e professores brasileiros, principalmente daqueles que se encontram mais isolados, com menor contato com a produção pedagógica atual.

Nesse sentido, Cysneiros (1999) cita que nas grandes cidades, as salas de aula têm pouco espaço físico, são ruidosas, quentes e escuras, desencorajando qualquer outra atividade que não seja a aula tradicional. A arquitetura pobre e o mobiliário desconfortável e precário dificultam o trabalho intelectual de alunos e mestres, que encontram-se sobrecarregados com aulas em mais de um estabelecimento, falta-lhe tempo para estudar e experimentar coisas novas e recebe baixos salários.

Para Bizerril (2001), é bastante preocupante a questão da baixa valorização desse profissional, pois a boa qualidade da educação e a formação de cidadãos comprometidos com a melhoria da sociedade e das relações do homem com a natureza dependem de bons profissionais, que deverão receber formação adequada, possibilidade de realização de estudos de atualização dos conhecimentos, tempo para elaboração e avaliação de projetos e aulas, valorização pela sociedade e recompensa financeira digna. 
Cysneiros (1991) diz que, para a formação básica de uma criança e para resolução dos problemas que alguém encontra no dia a dia, as informações mais relevantes são aquelas amadurecidas pelas gerações passadas, pelo tempo, ou aquelas encontradas na própria comunidade, acessíveis através de meios mais simples como jornais e pelo contato humano no próprio grupo social e que, além do prazer da descoberta e da criação, é necessário disciplina, persistência, suor e tolerância à frustração.

Por sua vez, Aragão (2006) diz que, para inovar, é fundamental conhecer as possibilidades dos alunos, consistindo estas em aspecto balizador do trabalho do professor e que a aceitação e a adesão a uma nova proposta de curso dependerão daquilo que os discentes têm condições de realizar. Caso a proposta exija, por exemplo, esforços adicionais extraclasse, ignorar esse fator pode ter como conseqüência desempenhos insatisfatórios dos alunos.

Ainda de acordo com Faria (1997), um modo estimulante de buscar o interesse do aluno e tornar as aulas mais criativas é partir de um problema ou questão que tenha relação com a vida dele, facilitando o seu envolvimento pessoal e a compreensão dos fenômenos abordados. Segundo ela, os problemas ambientais tem uma aplicabilidade educacional muito grande: por um lado, despertam facilmente o interesse do aluno; por outro, favorecem sua inserção no meio em que vive, assim como favorecem também o ensino de ciências, cujos conteúdos podem ser encadeados a partir desses problemas.

Então, a Educação Ambiental é um meio muito útil para o ensino das ciências, bem como para o desenvolvimento de hábitos ambientalmente adequados à sustentabilidade dos locais em que vivem os jovens.

Deste modo, estudar a sustentabilidade por meio da educação ambiental ajusta-se perfeitamente a todos estes requisitos, daí o avanço e da proposta deste estudo, de trabalhar também os requisitos para o turismo sustentável por meio da escola, seja na perspectiva de comunidades receptoras de turismo, seja como cidadãos que o façam. 
Nesse sentido, a Conferência Intergovernamental de Educação Ambiental de Tbilisiз definiu como princípios a serem desenvolvidos pelas escolas quanto à Educação Ambiental as seguintes premissas:

- considerar o meio ambiente em sua totalidade: em seus aspectos natural e construído, tecnológicos e sociais (econômico, político, histórico, cultural, técnico, moral e estético);

- aplicar um enfoque interdisciplinar, aproveitando o conteúdo específico de cada área, de modo que se consiga uma perspectiva global da questão ambiental;

- examinar as principais questões ambientais do ponto de vista local, regional, nacional e internacional;

- concentrar-se nas questões ambientais atuais e naquelas que podem surgir, levando em conta uma perspectiva histórica;

- insistir no valor e na necessidade da cooperação local, nacional e internacional para prevenir os problemas ambientais;

- considerar de maneira explícita os problemas ambientais nos planos de desenvolvimento e crescimento;

- promover a participação dos alunos na organização de suas experiências de aprendizagem, dando-lhes a oportunidade de tomar decisões e aceitar suas conseqüências;

- estabelecer, para os alunos de todas as idades, uma relação entre a sensibilização ao meio ambiente, a aquisição de conhecimentos, a atitude para resolver os problemas e a clarificação de valores, procurando, principalmente, sensibilizar os mais jovens para os problemas ambientais existentes na sua própria comunidade;

- ajudar os alunos a descobrir os sintomas e as causas reais dos problemas ambientais (tanto as locais quanto as mais amplas, de acordo com as possibilidades de compreensão em cada fase ou ciclo do ensino);

- ressaltar a complexidade dos problemas ambientais e a necessidade de desenvolver o sentido crítico e atitudes necessárias para resolvê-los; e

- utilizar diversos ambientes com a finalidade educativa e uma ampla gama de métodos para transmitir e adquirir conhecimento sobre o meio ambiente, ressaltando principalmente as atividades práticas e as experiências pessoais.

3 - Em 1977 foi realizada a Conferência Intergovernamental de Educação Ambiental em Tbilisi (ex-URSS) organizada pela UNESCO com a colaboração do PNUMA. Foi o ponto culminante da primeira fase do Programa Internacional de Educação Ambiental, iniciado em 1975. Definiu-se os objetivos, as características da EA, assim como as estratégias pertinentes no plano nacional e internacional. No Brasil, o Conselho Federal de Educação tornou obrigatória a disciplina Ciências Ambientais em cursos universitários de Engenharia. 
Estes aspectos relativos à educação ambiental deveriam estar inseridos nas atividades regulares das escolas e do ensino que promovem, mas essa ainda não é a realidade.

Nesse sentido, os principais documentos nacionais e internacionais que podem contribuir como instrumento para o ensino da EA são:

- Declaração de Estocolmo: Conferência das Nações Unidas sobre o Ambiente Humano - Estocolmo/1972;

- Seminário de Educação Ambiental/1974 - Jamir/Finlândia;

- Carta de Belgrado: Encontro Internacional em Educação Ambiental - Programa Internacional de Educação Ambiental - Belgrado (ex-lugoslávia, atual Sérvia)/1975;

- I Conferência Intergovernamental sobre Educação Ambiental - Objetivos, Princípios e Fundamentos da E.A - Tbilisi/1977;

- Il Congresso Internacional de Treinamento e Educação Ambiental - Moscou/1987;

- Conferência das Nações Unidas para o Meio Ambiente e Desenvolvimento Rio/92;

- Agenda 21 Capítulo 36 - Promoção do ensino, da conscientização e do treinamento;

- Fórum Global das ONGs - Encontro de Educação Ambiental para Sociedades Sustentáveis;

- Tratado de E.A. para as Sociedades Sustentáveis e Responsabilidade Global;

- Parâmetros Curriculares Nacionais - PCNs/1996;

- Conferência Internacional sobre Meio Ambiente e Sociedade: Educação e Conscientização Pública para a Sustentabilidade - Thessalonik, Grécia/1997;

- I Conferência Nacional de Educação Ambiental, Declaração de Brasília para a Educação Ambiental - Brasília/1997;

- Programa Nacional de Educação Ambiental/1999. Política Nacional de Educação Ambiental; e

- Agenda 21 Brasileira - 2002.

\section{3 - A Agenda 21 e o Desenvolvimento Sustentável}

De acordo com o Instituto do Meio Ambiente e dos Recursos Hídricos do Distrito Federal (IBRAM), a Agenda 21 não é apenas um documento. É um processo de participação em que a sociedade, os governos, os setores econômicos e sociais 
sentam-se à mesa para diagnosticar os problemas, entender os conflitos envolvidos e pactuar formas de resolvê-los, de modo a construir o que tem sido chamado de sustentabilidade ampliada e progressiva.

$\mathrm{Na}$ Conferência das Nações Unidas sobre o Ambiente Humano, em 1972, em Estocolmo, chegou-se à conclusão de que era preciso redefinir o próprio conceito de desenvolvimento, tantas e tão complexas eram as questões envolvidas. A tarefa ficou a cargo de uma comissão liderada pela primeira-ministra da Noruega, Gro Brundtland (hoje diretora da Organização Mundial de Saúde), que produziu em 1987 um relatório chamado Nosso Futuro Comum.

Nesse documento consolidava-se um novo conceito: desenvolvimento sustentável, aquele capaz de atender às necessidades das atuais gerações sem comprometer os direitos das futuras gerações e que apontava para a grande questão da humanidade hoje - reconhecer que o planeta é finito, não tem recursos infindáveis; por isso, a humanidade precisa adorar formatos de viver - padrões de produção e consumo - sustentáveis que não consumam mais recursos do que a biosfera terrestre é capaz de repor; não comprometam o meio ambiente; os muitos biomas do planeta, os seres que neles vivem, as cadeias alimentares reprodutivas; não degradem os seres humanos; além disso, os padrões de viver não poderiam sacrificar recursos e comprometer os direitos das futuras gerações.

Segundo o IBRAM, a partir desse documento, sucessivas discussões e conferências, as Nações Unidas prepararam a Conferência sobre Meio Ambiente e Desenvolvimento, que teria como palco o Rio de Janeiro, em junho de 1992 - era a RIO 92, que ali reuniria 179 chefes de estado e de governo. Um dos documentos centrais para a discussão era exatamente a proposta da Agenda 21, com princípios, programas, estratégias e propostas de ação. Juntamente com a Convenção sobre Mudanças Climáticas e a Convenção sobre Diversidade Biológica, a Agenda 21 acabou sendo um dos três grandes documentos aprovados no Rio de Janeiro pelos chefes de estado e de governo. Acreditava-se haver encontrado nas centenas de páginas desse documento o caminho para levar à prática o desenvolvimento sustentável.

De fato, o documento tratava de praticamente todas as grandes questões, dos padrões de produção e consumo à luta para erradicar a pobreza no mundo e às políticas de desenvolvimento sustentável - passando por questões como dinâmica demográfica, proteção a saúde, uso da terra, saneamento básico, energia e 
transportes sustentáveis, eficiência energética, poluição urbana, proteção a grupos desfavorecidos, transferência de tecnologias dos países ricos para os pobres, habitação, uso da terra, resíduos (lixo) e muito mais.

A Agenda 21 global já reconhecia que o desenvolvimento sustentável e a proteção do meio ambiente só seriam viáveis com o apoio das comunidades. Por isso, recomendava a construção das Agendas 21 locais.

Já na Conferência Rio+5, em 1997, estimou-se que 65 países já haviam definido sua Agenda 21, assim como duas mil comunidades locais. Na Cúpula Mundial sobre Desenvolvimento Sustentável, em Joanesburgo, África do Sul, em agosto de 2002, estimou-se que esse número já houvesse pelo menos dobrado. A Agenda 21 é composta por quatro seções amplas, que se subdividem em capítulos temáticos que são: Seção I: Dimensões Econômicas e Sociais; Seção II: Conservação e Manejo de Recursos para o Desenvolvimento; Seção III: Fortalecimento do papel dos Principais Grupos; e Seção IV: Meios de Implementação.

No Brasil, desde 1992, alguns estados e muitos municípios tomaram a iniciativa de construir suas Agendas 21. No plano nacional, esse processo começou em 1997, por iniciativa do Ministério do Meio Ambiente e, até sua conclusão, em 2002, envolveu cerca de 40 mil pessoas nas discussões nos estados, nas macrorregiões e em Brasília. É, com certeza, o mais amplo processo de participação para definir políticas públicas no País.

Entender os caminhos seguidos pode ajudar o processo a se ampliar, chegar a todos os estados, todos os municípios através da Comissão de Políticas de Desenvolvimento Sustentável (CPDS), como representantes do governo federal e de vários setores da sociedade. Essa Comissão decidiu fazer licitação pública para a realização de seis diagnósticos setoriais que apontassem o quadro vigente em seis áreas básicas, os problemas, os conflitos, as estratégias e as ações prioritárias. As áreas escolhidas eram: Gestão de recursos naturais; Agricultura sustentável; Cidades sustentáveis; Redução das desigualdades sociais; Infra-estrutura e integração regional; e Ciência e tecnologia para o desenvolvimento sustentável. Esses diagnósticos, com as críticas e sugestões incorporadas em Brasília transformaram-se no documento Agenda 21 Brasileira - Bases para discussão, que incluía uma síntese dos diagnósticos e suas propostas, bem como uma visão geral de cada uma das áreas tratadas. 
O novo documento recebeu milhares de propostas de acréscimos e supressões nas discussões a que foi submetido nos estados. Em fóruns de cada uma das macrorregiões do País chegou-se a novos documentos de caráter regional, em seguida levados a uma discussão final em Brasília.

Depois dessa e de novas discussões no âmbito da CPDS, o resultado foi sistematizado na Agenda 21 brasileira. Atualmente já há a formação das Agendas Locais na expectativa de alcançar e discutir os problemas e as necessidades de cada Região Administrativa do Distrito Federal, com destaque para: as Agendas 21 DF; Agenda 21 Escolar - Escola da Natureza; Agendas 21 em escolas do DF; Rede de Agendas 21 Locais; e Agendas 21 Locais no Centro-Oeste;

Diante disso, torna-se necessário destacar as atuações do Instituto do Meio Ambiente e dos Recursos Hídricos do Distrito Federal - Brasília Ambiental (IBRAM) criado em 28 de maio de 2007 por meio da Lei oㅜ 3.984, para ser o órgão executor de políticas públicas ambientais e de recursos hídricos no Distrito Federal.

O IBRAM possui autonomia administrativa, financeira e patrimonial e tem como meta principal propiciar o desenvolvimento sustentável da região de forma a garantir à população os benefícios alcançados pelo crescimento econômico, sem pôr em risco a qualidade de vida dos moradores do Distrito Federal e suas principais atribuições são:

- Implementar as medidas das políticas ambiental e de recursos hídricos de acordo com a legislação pertinente;

- Coordenar o processo de licenciamento das atividades com potencial poluidor em todo o Distrito Federal e planejar as ações de fiscalização, podendo aplicar penalidades disciplinares ou compensatórias ao não cumprimento das medidas necessárias à preservação ambiental;

- Executar a política de uso e conservação dos parques e outras áreas protegidas. Identificar e promover a demarcação e a implantação dos corredores ecológicos do Distrito Federal, bem como proteger a integração de ecossistemas, de espécies, do patrimônio natural e genético de representatividade ecológica do Distrito Federal;

- Planejar e supervisionar o monitoramento da qualidade ambiental, dos recursos hídricos, de clima e tempo no Distrito Federal; e

- Realizar estudos, programas e projetos voltados para a educação e conscientização ambiental das comunidades, além de propor normas, padrões e indicadores de qualidade ambiental e dos recursos hídricos. 
Uma das atividades de maior destaque do IBRAM é a realização de cursos e palestras gratuitos em escolas, associações e instituições governamentais e se empenha em conscientizar e promover informação sobre a temática ambiental e cujos temas são: Prevenção de Incêndios Florestais; Resíduos Sólidos: A Responsabilidade de Cada Um; Biodiversidade; Uso e Ocupação do Solo; A Viagem e suas Ambientalidades (voltado para profissionais da área do turismo); Educação Ambiental e o Distrito Federal; Agenda 21 Local, Escolar e Regional; Ecologia Alimentar; O Desenvolvimento Sustentável e o Cidadão; Recursos Hídricos; Horta Escolar; e Agroecologia.

Assim, o IBRAM tornou-se um dos principais órgãos articuladores envolvidos na construção das Agendas 21 local, com destaque para a Agenda 21 Escolar, importante instrumento do ensino da EA nas escolas do Distrito Federal.

\subsection{1 - Agenda 21 Escolar}

A partir do relatório chamado "Nosso Futuro Comum", as Nações Unidas prepararam a Conferência sobre Meio Ambiente e Desenvolvimento, que teria como palco o Rio de Janeiro, em junho de 1992 - era a RIO 92. Um dos documentos centrais para a discussão era exatamente a proposta da Agenda 21, com princípios, programas, estratégias e propostas de ação e que já reconhecia que o desenvolvimento sustentável e a proteção do meio ambiente só seriam viáveis com 0 apoio das comunidades locais. Por isso, recomendava que se iniciasse o processo de construção das Agendas 21 específica de cada localidade.

Como vimos, no Brasil, desde 1992, houve iniciativa de construir Agendas 21 e, até sua conclusão em 2002, cerca de 40 mil pessoas estiveram envolvidas nas discussões nos estados. Este novo documento recebeu milhares de propostas de acréscimos e supressões nas discussões a que foi submetido nos estados. Em fóruns de cada uma das macrorregiões do País chegou-se a novos documentos de caráter regional, em seguida levados a uma discussão final em Brasília e, atualmente no Distrito Federal, já discutem-se a formação das Agendas Locais na expectativa de alcançar e discutir os problemas e as necessidades de cada Região Administrativa.

Diante disso, pode-se destacar a Agenda 21 Escolar, importante instrumento do ensino da EA nas escolas do Distrito Federal e que será uma poderosa 
ferramenta de aplicação no meio de influência da escola, tanto nos recintos escolares, como no meio familiar e social onde tal influência é exercida. Ela visa a sustentabilidade social e econômica, atendendo às necessidades humanas para uma vida digna e a proteção do meio ambiente, tanto o ambiente utilizado pelos cidadãos, como formados pelos ecossistemas da região.

Para o IBRAM, para cada "escola piloto" deveria ser desenvolvida uma Agenda 21 Escolar, a fim de sensibilizar toda comunidade, engajando, professores, pais e alunos na busca dos valores sócio-ambientais em sua realidade diária. A Agenda 21 escolar é a formatação do texto base da Agenda 21 local para aplicação no meio de influência da escola, tanto nos recintos escolares, como no meio familiar e social onde tal influência seja exercida. Visa, da mesma forma que as demais agendas, a sustentabilidade ambiental, social e econômica, atendendo às necessidades humanas para uma vida digna e a proteção do meio ambiente, tanto o ambiente utilizado pelos cidadãos, como os formados pelos ecossistemas da região. Os principais requisitos básicos para sua elaboração são:

- A adoção de uma metodologia de trabalho que deverá ser buscada por consenso entre representantes do estabelecimento escolar, dos alunos, da coletividade em sua área de influência, do poder público e de organismos não governamentais, voluntários, técnicos, líderes comunitários e religiosos, em reuniões previamente designadas para tanto;

- A realização de pesquisas para apuração dos problemas existentes na área de atuação da agenda, englobados os problemas de saúde da população local, de degradação do meio ambiente ou riscos ambientais, de segurança, problemas sociais diversos como desemprego, alcoolismo, uso de drogas, etc.; e

- Avaliação técnica, por pessoal habilitado, e consenso popular, através de reuniões, das soluções para estancar, reverter ou pelo menos amenizar os problemas, buscando os meios de sustentabilidade econômica da população, a melhora de sua qualidade de vida e a melhoria ambiental, com preservação de áreas, criação de novas áreas, saneamento, melhoria dos elementos já implantados, e, essencialmente, educação de cunho social e ambiental.

Dentro desses princípios foi inaugurada pelo IBRAM, no dia 02 de junho de 2009, a Escola Águas Claras de Educação Ambiental, no Parque Ecológico de Águas Claras/DF, que merece destaque especial em virtude de propiciar os ensinamentos de EA e que será utilizado pelos freqüentadores do Parque Ecológico 
para cursos, palestras, mostras e oficinas de artesanato com materiais recicláveis, tornando-se um excelente atrativo para as atividades externas dos alunos do ensino fundamental do Distrito Federal. Esta foi a única experiência encontrada, dentro do modelo, e deve servir de referência para outras experiências.

\section{4 - Fundamentos Conceituais do Turismo e a Sustentabilidade}

Para melhor embasamento do estudo, torna-se necessário conhecer os conceitos básicos do turismo e da sustentabilidade e suas correlações com a educação ambiental, pois esses pilares formam a base dos conteúdos do estudo.

A palavra turismo (significa volta - tourism e tourist) tem origem no Século XVIII: tur - Hebreu, tornare - Latim, tour - Francês e turn - Inglês.

Para se entender a amplitude da atividade turística, primeiramente, é importante a compreensão do conceito dessa palavra. Segundo Andrade (2004, p.38) "turismo é o complexo de atividades e serviços relacionados aos deslocamentos, transportes, alojamentos, alimentação, circulação de produtos típicos, atividades relacionadas aos movimentos culturais, visitas, lazer e entretenimento."

De uma forma bem simplificada, turismo é o estudo dos movimentos e das relações estabelecidas pelos indivíduos fora do seu local de residência. $O$ deslocamento de indivíduos de um local para outro é tão antigo quanto a história da humanidade, sendo motivado ao longo do tempo por vários fatores como: necessidade de proteção e abrigo contra as intempéries da natureza, busca de novos territórios para plantio e caça, viagens motivadas por recreação, saúde, estudo, religião, negócios e família.

Por outro lado, Silveira Bueno4 ensina que sustentabilidade é a característica ou condição do que é sustentável. Sustentável é o que pode ser sustentado. Sustentado é o que se sustenta ou sustentou ou, na música, é aquilo que é mantido por mais tempo que o normal.

A Professora lara Brasileiro5 também menciona que sustentabilidade "é a característica do que é sustentável, que é aquilo que pode ser sustentado que, por sua vez, é o que se sustenta ou sustentou. 
Já a OMT6 define o turismo sustentável como aquele que atende às necessidades dos turistas de hoje e às das regiões receptoras, ao mesmo tempo em que protege e amplia as necessidades para o futuro, sem desprezar a manutenção da integridade cultural, dos processos ecológicos essenciais, da diversidade biológica e dos sistemas que garantem a vida. Assim, a sustentabilidade do turismo ganha importância central na era pós-moderna.

Para Miranda (2004)7, o desafio do desenvolvimento sustentável é o de prover o melhor para a humanidade e o meio ambiente hoje, no futuro e indefinidamente. Segundo o Autor, o conceito de sustentabilidade foi consagrado pela primeira vez no relatório "Nosso Futuro Comum", elaborado pela Comissão Mundial sobre o Meio Ambiente e Desenvolvimento da ONU e publicado em 1987.

Assim, em qualquer comunidade com perfil turístico, a escola também precisa ser envolvida e, quanto mais inserido nos programas de ensino estiverem os aspectos relativos à sustentabilidade ambiental lato sensu (considerando todo o meio ambiente, com suas variáveis ecológicas, econômicas, sociais e educacionais), maior são as possibilidades de sucesso, sendo que a condição de gestão do projeto é peça decisiva e deve ser feita permanentemente, integrando as diversas variáveis atuantes, inclusive os seus processos interativos.

Essa gestão integrada só será possível de ser feita se houver um quadro detalhado das condições locais, indicando todas as partes que compõem o (sub)sistema a ser gerido pelo empreendimento turístico. E a escola local também faz parte deste sistema. Seus programas de ensino devem envolver as questões da educação ambiental e da sustentabilidade do meio ambiente.

Buscando a inserção da escola neste processo, podemos identificar as orientações do Ministério da Educação quanto às problemáticas sociais em relação à ética, saúde, meio ambiente, pluralidade cultural, orientação sexual, trabalho e consumo que são integradas na proposta educacional daquele ministério para os PCN's como Temas Transversais. Não se constituem em novas áreas, mas num conjunto de temas que aparecem transversalizados, permeando a concepção das diferentes áreas, seus objetivos, conteúdos e orientações didáticas.

6 - OMT - Organização Mundial de Turismo

7 - Evaristo Eduardo de Miranda, agrônomo, com mestrado e doutorado em Ecologia na França, e pesquisador da Embrapa. 
Daí considerarmos essencial que a questão da sustentabilidade, inclusive no turismo, vir a ser analisada em função dos PCN's e as possibilidades de vir a ser trabalhado como conteúdo programático do Tema Transversal Meio Ambiente. $\mathrm{O}$ conjunto desses temas discute a necessidade de a escola considerar valores gerais e unificadores que definam seu posicionamento em relação à dignidade da pessoa, à igualdade de direitos, à participação e à co-responsabilidade de trabalhar pela efetivação do direito de todos à cidadania.

Diante disso, é que o objetivo deste estudo é discutir e inserir no ensino a questão da sustentabilidade no turismo, trabalhado a partir do Tema Transversal do Meio Ambiente nas Orientações Curriculares do Ensino Fundamental do DF, especialmente voltadas para o ensino fundamental do $6^{\circ}$ ao $9^{\circ}$ anos.

A preocupação é como o ensino fundamental pode contribuir para a sustentabilidade ambiental e, portanto, também para o turismo sustentável, no caso daquelas comunidades que têm vocação para o turismo. O estudo vai se restringir à abordagem do currículo do ensino fundamental com destaque para o DF e, portanto, mais voltado especialmente para as escolas públicas, já que estas são reguladas pelo GDF, mas estas orientações também deverão ser seguidas pelas escolas privadas.

Entende-se que a questão da sustentabilidade ambiental e, portanto, também do tema "turismo sustentável" pode ser inserido nos debates educacionais desde as primeiras séries de ensino, obedecendo às particularidades e características de cada região ou bioma do País. Além de abordar os reflexos da exploração desordenada dessas localidades para seus povos, suas floras e faunas, outros aspectos formativos de uma nova atitude ambiental devem também ser abordadas, pois certamente novos cidadãos serão formados a partir de crianças e jovens conscientizados da nova ordem ambiental, de seus direitos e deveres.

Assim, há também a necessidade da capacitação do corpo docente para a temática, de modo a levarem aos seus alunos a mensagem da preservação para a manutenção da própria espécie humana. 


\subsection{1 - O Turismo Sustentável e o Ensino Fundamental no Brasil}

Sendo um dos objetivos do estudo a relação entre o tema transversal meio ambiente e o turismo sustentável voltado para o ensino fundamental, há a necessidade de aprofundar o conhecimento sobre esses tópicos.

$\mathrm{Na}$ expectativa de alcançar, a médio e longo prazos, a meta de crescimento constante do turismo no Distrito Federal, destacam-se como pontos básicos, as soluções visando encontrar caminhos para combater as atividades "clandestinas" ou formas irregulares de exploração, além de disponibilizar recursos humanos e materiais capazes de atender à crescente demanda da atividade, através de parcerias entre a iniciativa privada e o governo, gerando um apelo econômico-social e cultural para o desenvolvimento dessas regiões.

Segundo matéria de capa do principal jornal da Capitals, o Brasil alcançou considerável IDH , ascendo ao seleto rol das nações de desenvolvimento humano elevado, ao atingir a barreira de 0,8 no índice (que varia de zero a um) segundo as Nações Unidas para o Desenvolvimento (PNUD), porém ficando na $70^{a}$ colocação atrás de países como a Albânia e Arábia Saudita.

$O$ dado mostra, ainda, o quanto é necessário crescermos para nivelarmos às principais nações desenvolvidas, buscando o perfeito equilíbrio entre as regiões ricas e pobres do País. Assim, será possível classificar as atividades turísticas daquelas localidades como alvos em potenciais desenvolvimento, ladeados pelas metas básicas de educação, segurança e saúde, triviais para a formação do cidadão, embora o número sinalize uma considerável evolução.

Mas, de que adianta tudo isso se nas escolas não há um plano de evolução sobre o tema "turismo sustentável e meio ambiente" condizente e que projete 0 aumento das taxas de desenvolvimento humano esperado para um País do futuro.

Alguns indicadores quantitativos e qualitativos mostram o longo caminho a percorrer em busca dessa eqüidade, pois, comparações com outros países em estágio equivalente de desenvolvimento colocam o Brasil em desvantagem na área da educação. Os dados revelam desigualdades regionais, baixo aproveitamento escolar, defasagem idade/série, índices de evasão e repetência. 
Esses resultados refletem o processo de extrema concentração de renda e de níveis elevados de pobreza ainda existentes no país, embora a educação no Distrito Federal alcance índices superiores à média nacional. Já a profunda segmentação social, decorrente da iníqua distribuição de renda, tem funcionado como um entrave para que uma parte considerável da população possa fazer valer os seus direitos e interesses fundamentais, como o direito à educação.

No entanto, análise sobre o recente desempenho do sistema de ensino também aponta avanços importantes e consistentes em direção à superação do atraso educacional. Em termos gerais, houve uma queda da taxa de analfabetismo, aumento expressivo do número de matrículas em todos os níveis de ensino e crescimento sistemático das taxas de escolaridade média da população. Percebe-se o engajamento das autoridades ao apresentarem projetos e desenvolvimento de ações de turismo sustentável e promoção turística em vários estados, alcançando cifras milionárias, mas que são corroídas por irregularidades em sua aplicação, o que deve ser matéria de auditora constante das áreas competentes.

\section{5 - A Lei de Diretrizes e Bases da Educação Nacional - LDB no 9.394/96}

A LDB 9394/96, promulgada em 20 de dezembro de 1996, é a lei orgânica e geral da educação brasileira. Como o próprio nome diz, dita as diretrizes e as bases da organização do sistema educacional e seu Relator foi o Senador Darcy Ribeiro10,

Alguns pontos da LDB são considerados ganhos importantes para os cidadãos: "a educação escolar deverá vincular-se ao mundo do trabalho e à prática social” (art.1); "a União deve gastar no mínimo 18\% e os estados e municípios no mínimo $25 \%$ de seus orçamentos na manutenção e desenvolvimento do ensino público" (art. 69); e o Ensino fundamental passa a ser obrigatório e gratuito (art. 4).

\footnotetext{
10 - Darcy Ribeiro (Montes Claros, 26 de outubro de 1922 - Brasília, 17 de fevereiro de 1997) foi um antropólogo, escritor e político brasileiro que se preocupava com os índios e a educação do país. Notabilizou-se fundamentalmente por trabalhos desenvolvidos nas áreas de educação, sociologia e antropologia tendo sido, ao lado do amigo a quem admirava Anísio Teixeira, um dos responsáveis pela criação da Universidade de Brasília, elaborada no início dos anos sessenta, ficando também na história desta instituição por ter sido seu primeiro reitor. Darcy Ribeiro também foi ministro-chefe da Casa Civil do presidente João Goulart, vice-governador do Rio de Janeiro de 1983 a 1987 e exerceu o mandato de senador pelo Rio de Janeiro, de 1991 até sua morte - anunciada por um lento processo canceroso, que comoveu todo o Brasil em torno de sua figura: Darcy, sempre polêmico e ardoroso defensor de suas idéias, teve em sua longa agonia o reconhecimento e admiração até dos adversários.
} 
"O mais interessante da LDB é que ela foge do que é infelizmente o mais comum na legislação brasileira: ser muito detalhista. Ela dá muita liberdade para as escolas, para os sistemas de ensino dos municípios e dos estados, fixando normas gerais. É uma lei exemplar." (ex-ministro Paulo Renato Souza, 2008,pág 1)11

Nesse sentido, o Ministério da Educação lembra que o ensino fundamental compõe, juntamente com a educação infantil e o ensino médio, o que a nova LDB nomeia como educação básica e que tem por finalidade "desenvolver o educando, assegurar-Ihe a formação indispensável para o exercício da cidadania e fornecer-lhe meios para progredir no trabalho e em estudos posteriores".

No Artigo 26 encontra-se importante premissa fundamental para o estudo quando diz que: "Os currículos do ensino fundamental e médio devem ter uma base nacional comum, a ser complementada, em cada sistema de ensino e estabelecimento escolar, por uma parte diversificada, exigida pelas características regionais e locais da sociedade, da cultura, da economia e da clientela". Assim, fica evidente que é cabível a inserção de temas voltados à sustentabilidade e o turismo no Ensino Nacional, com destaque para o que chama de "características regionais e locais".

No Art. 32 da mesma Lei afirma que "o ensino fundamental obrigatório, com duração de 9 anos, gratuito na escola pública, iniciando-se aos 6 anos de idade, terá por objetivo a formação básica do cidadão, mediante:

I - o desenvolvimento da capacidade de aprender, tendo como meios básicos o pleno domínio da leitura, da escrita e do cálculo;

II - a compreensão do ambiente natural e social, do sistema político, da tecnologia, das artes e dos valores em que se fundamenta a sociedade;

III - o desenvolvimento da capacidade de aprendizagem, tendo em vista a aquisição de conhecimentos e habilidades e a formação de atitudes e valores; e IV - o fortalecimento dos vínculos de família, dos laços de solidariedade humana e de tolerância recíproca em que se assenta a vida social." (Redação dada pela Lei no 11.274, de 2006).

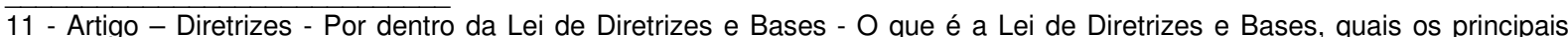
ganhos para os cidadãos e a história até sua aprovação em 1996. - 26/08/2008 12:23 - Texto - Lu Scuarcialupi - disponível em http://educarparacrescer.abril.com.br/politica-publica/lei-diretrizes-bases-349321.shtml - pág 1. 
Os fatores elencados acima são de vital importância para a evolução da educação no País e a consequente aplicabilidade dos temas voltados para a preservação do meio ambiente num plano de turismo sustentável. Para tal, o instrumento de ligação educação/meio ambiente são as referências dos PCN's.

\section{6 - Os Parâmetros Curriculares Nacionais - PCN's}

Os PCN's foram elaborados pela Secretaria de Educação Fundamental do MEC em 1998 e o terceiro e quarto ciclos tratam das séries e anos finais do ensino fundamental (do 6ำ ao 9ำ anos), cujas prerrogativas são, de um lado, respeitar diversidades regionais, culturais, políticas existentes no país e, de outro, considerar a necessidade de construir referências nacionais comuns ao processo educativo em todas as regiões brasileiras, com a pretensão de criar condições que permitam acessos dos jovens ao conjunto de conhecimentos socialmente elaborados e reconhecidos como necessários ao exercício da cidadania.

"O papel fundamental da educação no desenvolvimento das pessoas e das sociedades amplia-se ainda no novo milênio e aponta para a necessidade de se construir uma escola voltada para a formação de cidadãos. Esperamos que os Parâmetros sirvam de apoio às discussões e ao desenvolvimento do projeto educativo, à reflexão sobre a prática pedagógica, ao planejamento de suas aulas, à análise e seleção de materiais didáticos e de recursos tecnológicos e, em especial, que possam contribuir para sua formação e atualização profissional." (Sr. Paulo Renato Souza - Ex Ministro da Educação, pág 4).

Especificamente quanto ao Parâmetro Curricular do Meio Ambiente PCN/MEC (pág's 237 a 239) conhecer o significado mais preciso dos termos e as leis de proteção ambiental que incidem sobre a região em que a escola se insere é importante para os professores. Por sua função em oferecer oportunidades para que os alunos se exercitem no desempenho da cidadania e, mais ainda, para que a escola saiba como assumir sua responsabilidade como instituição do bairro, do município, como parte da sociedade local instituída, objetivando a prepararão dos alunos no sentido deles perceberem como parte integrante, dependente e agente transformador do ambiente, identificando seus elementos e as interações entre eles, contribuindo ativamente para a melhoria do meio ambiente.

No entanto, teoricamente, os objetivos estão muito bem estruturados, mas essa não é a realidade das salas de aulas, principalmente da rede pública de ensino que, em sua maioria, buscam condições mínimas de ensino (salas de aulas 
equipadas, mobiliário adequado, professores bem remunerados e preparados e conteúdos de ensino atualizados). A proposta de organização do conhecimento, nos Parâmetros Curriculares Nacionais, está em consonância com o disposto no Artigo 26 da Lei de Diretrizes e Bases, que assim se pronuncia: "Os currículos do ensino fundamental e médio devem ter uma base nacional comum, a ser complementada, em cada sistema de ensino e estabelecimento escolar, por uma parte diversificada, exigida pelas características regionais e locais da sociedade, da cultura, da economia e da clientela."

Os diferentes parágrafos desse artigo apresentam as diretrizes gerais para a organização dos currículos do ensino fundamental e médio, que são:

- devem abranger, obrigatoriamente, o estudo da língua portuguesa e da matemática, o conhecimento do mundo físico e natural e da realidade social e política, especialmente do Brasil;

- o ensino da arte constituirá componente curricular obrigatório, nos diversos níveis da educação básica, de forma a promover o desenvolvimento cultural dos alunos;

- a educação física, integrada à proposta pedagógica da escola, é componente curricular da educação básica, ajustando-se às faixas etárias e às condições da população escolar, sendo facultativa nos cursos noturnos;

- o ensino da história do Brasil levará em conta as contribuições das diferentes culturas e etnias para a formação do povo brasileiro, especialmente das matrizes indígena, africana e européia;

- na parte diversificada do currículo será incluído, obrigatoriamente, a partir da quinta série, o ensino de pelo menos uma língua estrangeira moderna, cuja escolha ficará a cargo da comunidade escolar, dentro das possibilidades da instituição.

Assim, a inserção da sustentabilidade no tema transversal "meio ambiente" atende a todos estes requisitos, de modo integrado, com os alunos adquirindo habilidades e competências com a língua portuguesa e estrangeira, o mundo físico e natural, a realidade social e política, não só do Brasil, mas também de sua região específica, envolvendo os conhecimentos da história e geografia, habilitando-se também às aplicações artísticas, inclusive artesanais, além de vigor físico para percorrer, apreciar e proteger as paisagens naturais do ambiente que vive. 


\section{7 - O Tema Transversal Meio Ambiente nos PCN's}

Os temas transversais são os eixos geradores de conhecimentos, a partir das experiências dos alunos, assim como os eixos de união entre as matérias tradicionais dos quais devem girar a temática das áreas curriculares. Estes temas estariam presentes, portanto, de maneira diversa, na totalidade de matérias da estrutura curricular.

De acordo com o Ministério da Educação, a transversalidade pressupõe um tratamento integrado das áreas e um compromisso com as relações interpessoais no âmbito da escola, pois os experimentos na vivência escolar e a coerência entre eles devem ser claros para desenvolver a capacidade dos alunos de intervir na realidade e transformá-la, tendo essa capacidade relação direta com o acesso ao conhecimento acumulado pela humanidade.

Para estar em consonância com as demandas atuais da sociedade, é necessário que a escola trate de questões que interferem na vida dos alunos e com as quais se vêem confrontados no seu dia-a-dia. As temáticas sociais vêm sendo discutidas e freqüentemente são incorporadas aos currículos das áreas, especialmente nos de história, geografia e ciências naturais ou em novas áreas.

Mais recentemente, algumas propostas sugerem o tratamento transversal de temáticas sociais na escola, como forma de contemplá-las na sua complexidade, sem restringi-las à abordagem de uma única área. A Lei Federal LDB № 9.394/96, em seu artigo 27, inciso I, também destaca que os conteúdos curriculares da educação básica deverão observar "a difusão de valores fundamentais ao interesse social, aos direitos e deveres dos cidadãos, de respeito ao bem comum e à ordem democrática".

Nessa perspectiva, as problemáticas sociais em relação à ética, saúde, meio ambiente, pluralidade cultural, orientação sexual e trabalho e consumo são integradas na proposta educacional dos Parâmetros Curriculares Nacionais como Temas Transversais. Não se constituem em novas áreas, mas num conjunto de temas que aparecem transversalizados, permeando a concepção das diferentes áreas, seus objetivos, conteúdos e orientações didáticas, sendo que esse conjunto discute a necessidade de a escola considerar valores gerais e unificadores que definam seu posicionamento em relação à dignidade da pessoa, à igualdade de direitos, à participação e à co-responsabilidade de trabalhar pela efetivação do 
direito de todos à cidadania. Essa abrangência não significa que os temas transversais devam ser tratados igualmente em todos os lugares. Ao contrário, podem exigir adaptações para que correspondam às reais necessidades de cada região ou mesmo de cada escola. As questões ambientais, por exemplo, ganham características diferentes nos campos de seringais, no interior da Amazônia, na periferia de uma grande cidade ou no cerrado do Centro Oeste.

Quanto ao meio ambiente, os PCN's pregam que: a sustentabilidade pressupõe um comprometimento com a qualidade ambiental e com a gestão adequada do desenvolvimento econômico; a compreensão de que desgastes ambientais interligam-se uns aos outros; e que problemas econômicos e ambientais estão relacionados a muitos fatores políticos e sociais.

Esses são os princípios norteadores da problematização a ser feita pelas diferentes áreas de modo que torne mais visível e concreta a questão ambiental, sendo fundamental que os professores se perguntem que concepção de relação ser humano/natureza estão ajudando seus alunos a construir. A compatibilização entre a utilização dos recursos naturais e a conservação do meio ambiente, apesar de hoje ainda parecer somente uma utopia, deve ser um compromisso da humanidade. Isso pode se concretizar por meio de formas de produção que satisfaçam às necessidades do ser humano, sem destruir os recursos que serão necessários às futuras gerações.

Já a sustentabilidade tem sido discutida em todos os encontros e debates sobre a questão ambiental, uma vez que impõe, atualmente, um grande desafio à humanidade, baseando-se em um planejamento a longo prazo e no reconhecimento de que devemos admitir os limites dos recursos naturais que utilizamos para tornar nossa vida diária possível.

Diante disso os PCN's procuraram sintetizar alguns termos relacionados com a questão da sustentabilidade ambiental conforme definições extraídas da Organização Mundial da Saúde (OMS) e que são empregados pela legislação ambiental. Procurou-se manter a definição dada pela lei ou por órgãos nacionais e internacionais de Meio Ambiente e de Saúde.

Assim, tais conceitos passam a constituir temas que deverão ser utilizados e explorados pelos docentes, quais sejam:

- Proteção - Significa o ato de proteger. É a dedicação pessoal a aquele ou aquilo que dela precisa; é a defesa daquele ou daquilo que é ameaçado. O termo 
"proteção" tem sido utilizado por vários especialistas para englobar os demais: preservação, conservação, recuperação etc. Para eles, essas são formas de proteção. No Brasil há várias leis estabelecendo Áreas de Proteção Ambiental (APA's), assim definidos e delimitados pelo poder público (União, estado ou município), cuja proteção se faz necessária para garantir o bem-estar das populações presentes e futuras e o meio ambiente ecologicamente equilibrado. Nas APA's declaradas pelos estados e municípios poderão ser estabelecidos critérios e normas complementares (de restrição ao uso de seus recursos naturais), levando-se em consideração a realidade local, em especial a situação das comunidades tradicionais que porventura habitem tais regiões. $O$ uso dos recursos naturais nas APA's só pode se dar desde que "não comprometa a integridade dos atributos que justifiquem sua proteção" (CF, art. 225, § 10, III);

- Preservação - é a ação de proteger, contra a destruição e qualquer forma de dano ou degradação, um ecossistema, uma área geográfica ou espécies animais e vegetais ameaçadas de extinção, adotando-se as medidas preventivas legalmente necessárias e as medidas de vigilância adequadas. O Código Florestal estabelece áreas de preservação permanente, ao longo dos cursos d'água (margens de rios, lagos, nascentes e mananciais em geral), que ficam impedidas de qualquer uso. Essas áreas se destinam, em princípio, à vegetação ou mata ciliar especialmente importante para garantir a qualidade e a quantidade das águas, prevenindo 0 assoreamento e a contaminação. (CF, art. 225, § 10, I);

- Conservação - é a utilização racional de um recurso qualquer, para se obter um rendimento considerado bom, garantido-se, entretanto, sua renovação ou sua autosustentação. Analogamente, conservação ambiental quer dizer o uso apropriado do meio ambiente dentro dos limites capazes de manter sua qualidade e seu equilíbrio em níveis aceitáveis. Para a legislação brasileira, "conservar" implica manejar, usar com cuidado, manter; enquanto "preservar" é mais restritivo: significa não usar ou não permitir qualquer intervenção humana significativa;

- Recuperação - no vocabulário comum, é o ato de recobrar o perdido, de adquiri-lo novamente. O termo "recuperação ambiental" aplicado a uma área degradada pressupõe que nela se restabeleçam as características do ambiente original. Nem sempre isso é viável e às vezes pode não ser necessário, recomendando-se então uma reabilitação. Uma área degradada pode ser reabilitada (tornar-se novamente habilitada) para diversas funções, como a cobertura por vegetação nativa local ou 
destinada a novos usos, semelhantes ou diferentes do uso anterior à degradação. A lei prevê, na maioria dos casos, que o investimento necessário à recuperação ou reabilitação seja assumido pelo agente degradador. Além disso, o agente responsável pelo dano ambiental deve reparar esse dano. Reparação é o ressarcimento, para efeito de consertar ou atenuar dano causado à pessoa ou patrimônio, e, no caso de dano ambiental, além de provável pagamento de multa, pode envolver a obrigação de recuperar ou reabilitar a área degradada. (CF art. 225, $\left.\S 2^{\circ}\right)$;

- Degradação - degradação ambiental consiste em alterações e desequilíbrios provocados no meio ambiente que prejudicam os seres vivos ou impedem os processos vitais existentes. Embora possa ser causada por efeitos naturais, a forma de degradação que mais preocupa governos e sociedades é aquela causada pela ação antrópica, que pode e deve ser regulamentada. A atividade humana gera impactos ambientais que repercutem nos meios físicobiológicos e socioeconômicos, afetando os recursos naturais e a saúde humana, podendo causar desequilíbrios ambientais no ar, nas águas, no solo e no meio sociocultural. Algumas das formas mais conhecidas de degradação ambiental são: a desestruturação física (erosão, no caso de solos), a poluição e a contaminação. A poluição é a "introdução, no meio, de elementos tais como organismos patogênicos, substâncias tóxicas ou radioativas, em concentrações nocivas à saúde humana". Fala-se também em contaminação, "muitas vezes como sinônimo de poluição, porém quase sempre em relação direta sobre a saúde humana”. De fato, para a Organização Mundial da Saúde - órgão da ONU -, "poluição ou contaminação ambiental é uma alteração do meio ambiente que pode afetar a saúde e a integridade dos seres vivos".

Estes conceitos devem ser desenvolvidos nos programas de educação ambiental e de educação para o turismo, de modo a que os alunos aprendam a buscar a sustentabilidade do meio em que vivem, inclusive dos empreendimentos turísticos à sua volta.

A Figura 3 aponta os Objetivos Gerais do Ensino Fundamental e a exata posição onde está inserido o Tema Transversal do Meio Ambiente onde é proposta a inserção do tema "Turismo Sustentável" objetivando municiar os alunos de conceitos de sustentabilidade e turismo voltados para as regiões afetadas pela exploração do seu meio ambiente natural já que o Meio Ambiente não se restringe ao ambiente físico e biológico, mas inclui também as suas relações sociais, econômicas e culturais. $O$ objetivo é propor reflexões que levem o aluno ao enriquecimento cultural, à qualidade de vida e à preocupação com o equilíbrio ambiental. 
Figura 3 -Tema Transversal Meio Ambiente

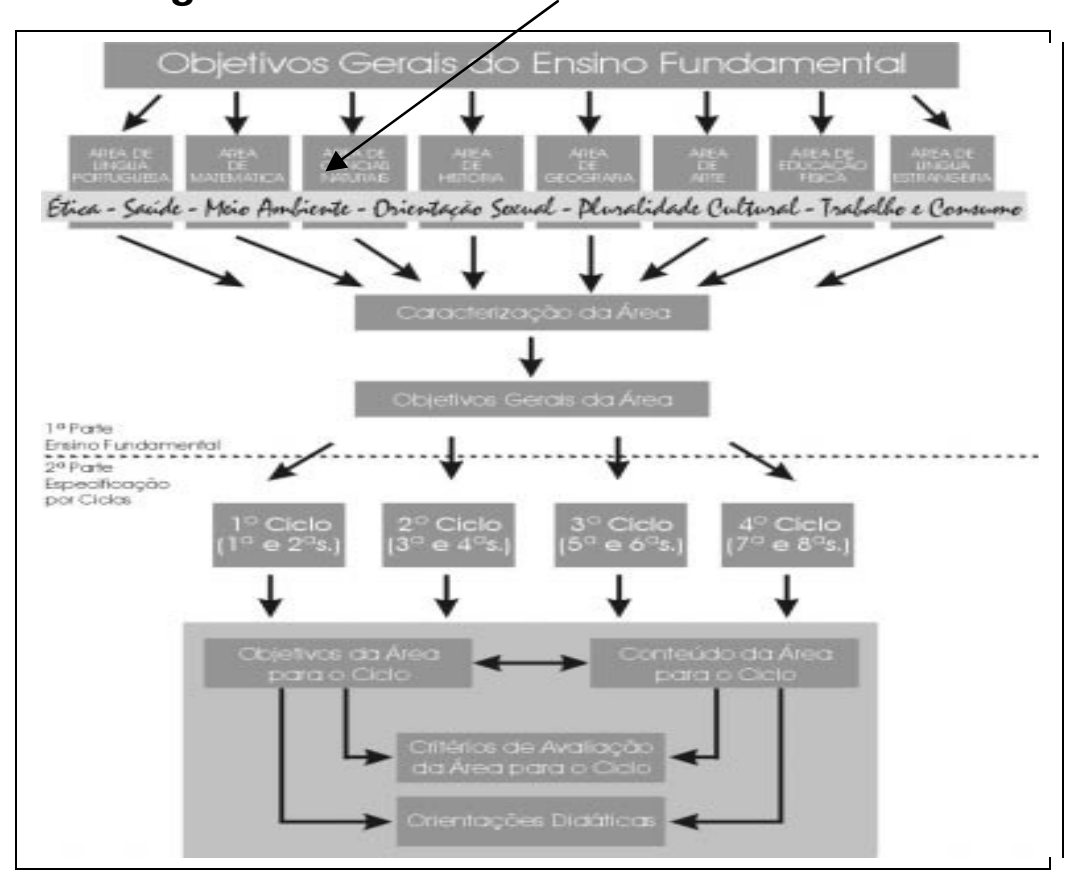

Para a Bueno (2002)12, O Tema Transversal Meio Ambiente deve ser trabalhado de forma implícita nas questões diárias de cada disciplina escolar. Ela entende que é preciso capacitar o aluno como cidadão que se veja como um ser histórico e relata que o tema transversal colocado nos PCN's veio a reboque da Agenda 21, trazendo uma questão relacionada à educação ambiental formal. Para ela, o MEC transformou esse tema (do meio ambiente) como transversal, o que não exigiria alguém especializado dando aulas de uma disciplina chamada meio ambiente. De qualquer maneira, foi sendo desenvolvido nas escolas muito precariamente porque a partir de um tema transversal tem-se ou não obrigatoriedade de usá-lo. Na verdade, todos os Parâmetros são apenas parâmetros. Então o tema ficou à mercê de objetivos dos projetos pedagógicos de cada escola, embora em 2001, foi sancionada uma lei que obriga as escolas a trabalharem com a educação ambiental, mas ainda não foi regulamentada.

"Os temas transversais são muito abrangentes e o professor não sabe muito bem o que fazer e como fazer.. Tenho encontrado nos cursos de capacitação muitos professores que não leram o tema transversal Meio Ambiente. Além disso, é também importante o educador conhecer a Agenda 21. O meio ambiente é um aspecto que foi trazido de fora para dentro da escola. Até uns dez anos atrás nossos livros didáticos não incluíam o ambiente como conteúdo importante."(Bueno, 2002, pág2)

12 - Artigo "Professores de mãos dadas com o meio ambiente" - Ebenezer de Menezes, da Agência EducaBrasil entrevista a Professora Tania Regina Moura Bueno, assessora pedagógica da OAK Educação e Meio Ambiente em 10/01/2002 - site www.midiamix.com.br acesso em 25/04/09. 
Nesse sentido, aprofundar os conhecimentos quanto ao meio ambiente, especialmente aquele em que está inserido quando em viagem, torna-se de vital importância para o desenvolvimento do aluno e, consequentemente, do cidadão.

Diante disso, é perfeitamente cabível a inserção do "Turismo Sustentável" como sub-tema do tema "Meio Ambiente" nos PCN's, guardadas as particularidades de cada região e localidade, conforme esteja mais ou menos relacionada com o turismo local, seja ela a mais desenvolvida ou não. Assim, os problemas, vantagens e reflexos da exploração da atividade passam a ser discutidos pelas pessoas mais interessadas e afetadas pelo uso de suas riquezas naturais, pois é inevitável que os turistas tenham acesso a essas localidades, mas que o façam obedecendo a princípios éticos de preservação daquele meio ambiente.

\section{8 - As Orientações Curriculares do Ensino Fundamental do DF}

Com base no currículo proposto para as Instituições Educacionais Públicas do Distrito Federal (2008), foram elaboradas algumas sugestões de modificação, com a devida argumentação teórica que a justifica, seja por supressão ou introdução de conteúdos ou por sugestão de novo ordenamento de conteúdos nas séries.

A partir do elenco de conteúdos propostos, foram indicadas as expectativas de aprendizagem para todos os anos e disciplinas dos ensinos fundamental e médio. Elas retomam os conteúdos e as habilidades indicados nesses documentos, no prisma de habilidades essenciais a serem desenvolvidas em cada componente curricular/ano escolar, de forma a indicar como o processo de ensino deve ser gerenciado para que ocorram devidamente as aprendizagens previstas no currículo ano a ano.

Para a definição e a organização das expectativas, foram considerados, os documentos curriculares; os princípios curriculares indicados para a organização das instituições educacionais públicas do Distrito Federal; e as habilidades e os conteúdos para os componentes curriculares e seus referenciais teóricos e metodológicos, que serão focos do processo de ensino-aprendizagem em sala de aula e assumidos na Proposta Pedagógica da Instituição Educacional e no Plano de Ensino dos Componentes Curriculares. 
É fundamental destacar, ainda, que os alunos aprendem aquilo que se ensina, e que a indicação das expectativas considera que serão utilizadas todas as formas possíveis para garantir as aprendizagens previstas no currículo para o ano/série nos componentes curriculares, inclusive os processos de recuperação de aprendizagem dos alunos.

Para o MEC, não é intenção esgotar todas as possibilidades de aprendizagens dos alunos, mas delimitar as fundamentais para cada ano/componente curricular e não é recente a abordagem curricular como objeto de atenção. Em cumprimento ao Artigo 210 da Constituição Federal de 1988, que determina como dever do Estado para com a educação "fixar conteúdos mínimos para o Ensino Fundamental, de maneira a assegurar a formação básica comum e respeito aos valores culturais e artísticos, nacionais e regionais", foram elaborados e distribuídos pelo MEC, a partir de 1995, os Referenciais Curriculares Nacionais para a Educação Infantil/RCNEI, os Parâmetros Curriculares Nacionais/PCN's para o Ensino Fundamental, e os Referenciais Curriculares para o Ensino Médio. Posteriormente, o Conselho Nacional de Educação definiu as Diretrizes Curriculares para a Educação Básica.

Outro fator a ser considerado é a relação da escola com o ambiente em que está inserida. Por ser uma instituição social que exerce intervenção na realidade, ela deve estar conectada com as questões mais amplas da sociedade, e com os movimentos amplos de defesa da qualidade do ambiente, incorporando-os às suas práticas, relacionando-os aos seus objetivos.

É também desejável a saída dos alunos para passeios e visitas em locais de interesse dos trabalhos em EA e que se faça um levantamento de locais como parques, unidades de conservação, lugares históricos e centros culturais, e se estabeleça um contato para fins educativos. No âmbito escolar, espera-se que o aluno acabe rejeitando as concepções equivocadas que têm sobre o fenômeno estudado, substituindo-as pelo ponto de vista da Ciência. Para que isto ocorra, devem ser criadas condições, em sala de aula, para que o aluno perceba como a nova idéia permite explicar, com vantagens sobre a sua concepção, o fenômeno estudado. Um processo que não é instantâneo e exige, portanto, que o aluno tenha oportunidade de vivenciar várias situações-problema, já que o que se quer é promover a "migração" de suas idéias - do senso comum para o conhecimento cientifico - e não simplesmente que os alunos descartem suas concepções prévias. 
E o que ensinar para os alunos nesta fase da escolarização? Em principio, a resposta é a mesma que se deu em relação às crianças: conteúdos que lhes interessem e que façam parte do seu cotidiano. Há evidências de que a aula expositiva (oral ou escrita) não é um bom procedimento didático. Qualquer que seja a estratégia selecionada, é fundamental que ela seja implementada de tal maneira a valorizar as concepções e interpretações dos alunos.

Da mesma forma, como o conhecimento se constrói pela interação, é necessário que se estabeleça em sala de aula um clima amigável. Dos alunos espera-se que sejam solicitados continuamente a dar explicações a respeito de fenômenos ou fatos, planejar, realizar experimentos, analisar resultados, de maneira a poder tirar conclusões. É claro que, segundo esta lógica, espera-se que sejam selecionados fenômenos "científicos" de relevância social para a vida dos alunos - e que possam contribuir para a sua formação como cidadão, pois a expectativa da aprendizagem não pretende reduzir os conhecimentos a serem ensinados/aprendidos, mas, sim, indicar os limites sem os quais o aluno teria dificuldades para prosseguir seus estudos, bem como participar ativamente na vida social e dos aspectos da sustentabilidade do meio em que vivem ou daquele que apreciará durante suas viagens.

Dentro dessa concepção e em relação ao DF, torna-se necessário conhecer suas características, o seu meio, ou seja o seu bioma natural, pois Bizerril (2001) já dizia que "o cerrado não é um tema tratado de modo transversal no ensino fundamental no DF, pois é discutido, na maioria das escolas, quase que exclusivamente em duas séries (6ำ e $7^{\circ}$ anos) e por duas disciplinas (geografia e ciências) e que é um tema que parece ser tratado, na maioria dos casos, de modo descritivo pois pouco é analisado em relação aos impactos negativos causados por determinadas ações antrópicas, como também em relação à diversidade biológica e cultural do bioma".

Segundo a Secretaria de Estado de Educação do Distrito Federal - SEDF, os conteúdos escolares refletem os significados e valores culturais e sociais que foram e são construídos no infinito processo de interação do homem com o mundo natural e social e são atualizados nas práticas de sala de aula quando o professor escolhe as metodologias mais adequadas para a aprendizagem, os recursos didáticos, os processos de avaliação e recuperação. 
Os conteúdos, quando associados às competências e habilidades que os alunos desenvolvem para transformá-los em conhecimento, podem ser expressos em termos das expectativas de aprendizagem, ou seja, de um conjunto de "fazeres e saberes" possíveis a partir da apropriação destes conteúdos, não apenas como algo que se repete na memória como o que resulta de operações mentais simples ou complexas que envolvem obrigatoriamente os sujeitos da aprendizagem - os alunos - e a indicação de expectativas de aprendizagem procura responder às solicitações dos educadores da rede que buscam referenciais comuns para organizar, acompanhar e implementar os projetos político-pedagógicos das escolas e as expectativas não substituem os planos dos professores, pois esses são singulares e refletem as diversas realidades locais que devem ser consideradas pela instituição educacional.

Assim, a indicação das expectativas de aprendizagem busca auxiliar na definição desses planos dos professores. Elas foram articuladas considerando os seguintes critérios indicados no Currículo do Distrito Federal relacionados a: relevância social e cultural da aprendizagem dos conteúdos escolares; ao construto das disciplinas; a relação didática entre os componentes curriculares; a potencialidade de desenvolvimento de competências e habilidades comuns pelos alunos em cada faixa etária; e a leitura e escrita como responsabilidade de todos os componentes curriculares.

O Órgão cita que essas expectativas refletem aquilo que se espera que os alunos aprendam na escola, traduzindo em práticas os objetivos e princípios previstos nos documentos curriculares organizados pelo Distrito Federal que apresentam quatro funções básicas:

1. Constituem referenciais para a realização de avaliação diagnóstica dos conhecimentos já dominados (ou não) pelos alunos em cada ano/componente curricular, levando-se em conta a implantação do novo currículo;

2. São indicadores de acompanhamento das aprendizagens básicas dos alunos ao longo dos anos escolares, procurando garantir que elas se consolidem, indicando a necessidade de processos de recuperação;

3. São referenciais mínimos para a análise das aprendizagens esperadas e consolidadas dos alunos e as necessidades de revisão do planejamento, inclusive avaliando o grau de implantação do próprio currículo oficial proposto; e

4. Oferecem maior clareza entre os elos que interligam o currículo proposto pela 
SEDF e as Matrizes de Referência para a Avaliação do Sistema de Avaliação do Desempenho das Instituições Educacionais do Sistema de Ensino do Distrito Federal- SIADE.

Em outras palavras, espera-se que os alunos atribuam novos significados aos fenômenos ou processos estudados, através de um processo de interação de novas idéias com conceitos que já existem em sua estrutura cognitiva. Um tipo de aprendizagem qualitativamente diferente da aprendizagem mecânica, em que simplesmente os estudantes armazenam um novo conhecimento, aprendizagem na qual o produto é a memorização.

Assim, a Educação, no Distrito Federal, adequada à Lei no 9.394/96, às Diretrizes Curriculares Nacionais, aos Parâmetros Curriculares Nacionais e à Resolução 2/98 do Conselho de Educação do Distrito Federal, dispõe de instrumento norteador atualizado e compatível com as exigências que o mundo, em processo de globalização e transformação, impõe à sociedade que necessita de novas condições, de novos instrumentos e de novos parâmetros e valores para modificar-se e aprimorar-se.

De acordo com a SEDF, do $6^{\circ}$ ao $9^{\circ}$ ano, privilegiam-se as aprendizagens significativas e a construção de competências. As disciplinas e respectivas cargas horárias reestruturam-se para atender às novas concepções filosóficometodológicas. O conteúdo não é um fim em si mesmo, mas um meio para o desenvolvimento de competências e habilidades. A assimilação de conceitos tornase um processo construtivo que atua na estrutura hierárquica, promovendo a diferenciação progressiva e a reconciliação interativa, princípios essenciais para a aquisição de aprendizagens significativas e desenvolvimento de habilidades e de competências.

Por esses princípios, o conhecimento ocorre, inicialmente, por uma diferenciação em relação aos conceitos pré-existentes, quando parece haver uma análise dos aspectos diversificadores, ou paradoxais, por dedução ou inferência, resultado da ação progressiva dos mecanismos mentais e, a seguir, uma reconciliação entre os conceitos antigos e os novos, por associação, paralelismo, síntese, enfim, que vai possibilitar a incorporação, a integração do conhecimento, que amplia a compreensão do mundo, desenvolve habilidades e competências. 
Nessa fase final do Ensino Fundamental, o Currículo procura vencer o academicismo e o anacronismo que, durante décadas, têm se instalado na Escola, promovendo uma distância considerável em relação à vida e aos processos sociais transformadores.

Para a SEDF, volta-se para uma necessária atualização de conhecimento e valores, numa perspectiva crítica, responsável e contextualizada, que privilegie a inteligência e a capacidade de alunos e professores vivenciarem os conhecimentos em seu enfoque interdisciplinar, onde todas as áreas se aproximam e possibilitam a análise da teia de relações entre seus aspectos comuns, diferentes e contraditórios.

O trabalho desenvolvido a partir dos Temas Transversais possibilita uma visão ampla e consciente da realidade e favorece a participação dos alunos na sociedade, tornando-os cidadãos capazes de analisar fatos criticamente e refletir sobre valores e atitudes importantes para o crescimento de uma sociedade mais justa. No processo de ensino e de aprendizagem, a transversalidade não se separa da interdisciplinaridade, afinal não há sentido em trabalhar questões relativas à vida, ao social, como disciplinas rígidas que não consideram a interação entre as áreas de conhecimento como meio de ampliar o saber e de desfragmentá-lo.

De acordo com a SEDF, os Temas Transversais não são novas áreas de conhecimento, nem se pretende que sejam trabalhados em aulas específicas. Eles serão diluídos nos conteúdos propostos, participando de forma integrada da construção do conhecimento. O estudo das Ciências Naturais no Ensino Fundamental tem-se orientado por diferentes tendências que, ainda, se expressam nas salas de aula. Hoje, considera-se o aluno como centro, o ambiente como base e o ensino de ciências voltado para o cotidiano do ponto de vista político-social.

Nesta proposta, a concepção de ensino e da aprendizagem de Ciências Naturais está fundamentada na Lei de Diretrizes e Bases da Educação Nacional no 9.394/96 - LDB e nos Parâmetros Curriculares Nacionais - PCN. Considera-se que o ensino deste componente curricular deve proporcionar ao estudante a constituição de pensamento científico acerca dos fenômenos naturais em diferentes espaços e tempos e a compreensão das transformações que o homem impõe à natureza, tendo como objetivo principal desenvolver no aluno competências essenciais ao exercício da cidadania, instrumentalizando-o para agir no mundo de forma crítica e consciente. 
Nessa concepção, aprofundar o nível de conhecimento sobre a educação, o meio ambiente e a inter-relação deles com o turismo sustentável torna-se uma meta preponderante e de aplicação aceitável para o Distrito Federal, pois cada escola precisa ostentar feição própria, desenvolver projetos que atendam às necessidades específicas de seus alunos, voltar-se para a comunidade, onde se insere, e acompanhar os avanços científicos tecnológicos. A partir de uma diretriz única, o Currículo elaborado com representação da coletividade, cada Escola deve buscar sua identidade que a particularize perante as demais.

Para a SEDF, essa identidade manifesta-se pela forma como a Escola vai desenvolvê-lo. Se, simplesmente aplicá-lo e julgar estar cumprindo as normas, caracterizar-se-à como uma instituição pouco criativa, nada inovadora, inerte, enfim, diante de um processo acelerado de transformações tecnológicas, sociais e culturais. Se, ao contrário, enriquecê-lo, inová-lo, contextualizá-lo, não só atenderá às Diretrizes Curriculares Nacionais, pois estará explicitando o reconhecimento da identidade pessoal de alunos, professores e outros profissionais, como também caracterizar-se-à como uma instituição criativa e dinâmica, capaz de fazer frente à rapidez da evolução hodierna.

Assim, de acordo com a SEDF, a Proposta Pedagógica reveste-se de fundamental relevância e impõe-se como instrumento particular de cada Escola para desenvolver o Currículo. Deve contemplar um estudo da sua própria realidade para levantamento de necessidades específicas, que não se limitam, apenas, aos aspectos físicos da Escola, mas ao clima psicológico da mesma e aos objetivos que pretende alcançar. Deve possibilitar o desenvolvimento não só dos projetos pedagógicos de cada Área de Conhecimento/Componente Curricular, como também o dos Temas Transversais, sugeridos pelo MEC, acrescidos daqueles que a Escola eleja como necessários à sua realidade.

Deve, ainda, estabelecer projetos multi e interdisciplinares, para execução ao longo do ano letivo, com vistas a incrementar a atuação pedagógica, o desempenho dos alunos, o prazer de ensinar/aprender, possibilitar momentos de auto avaliação, para verificar o percurso das ações, corrigir rumos, analisar resultados e ampliar metas, buscando conciliar os conceitos à pratica, ou seja. A ação de cidadania. 


\section{9 - A Interrelação do "Meio Ambiente", "Educação Ambiental" e "Turismo Sustentável”.}

De acordo com o Ministério do Meio Ambiente, o Programa de Regionalização do Turismo por meio de suas estratégias, articula a gestão coordenada, o planejamento integrado e participativo e a promoção e apoio à comercialização com o objetivo de estruturar e diversificar a oferta de modo a responder às demandas nacionais para a consolidação das atividades do turismo no País e, consequentemente, impulsionar o desenvolvimento sustentável.

O Plano incorpora, na sua transversatilidade, os princípios da política nacional de cultura por entender que turismo, meio ambiente e educação ambiental, aliados às organizações sociais, são componentes preponderantes de desenvolvimento socioeconômico desejado e buscar a compreensão e o equilíbrio entre esses fatores é muito importante, pois tais definições e objetivos se entrelaçam formando uma cadeia única de interesses e atitudes fundamentais para o desenvolvimento sustentável do local. Levar esses conhecimentos às salas de aula significa ampliar o nível de abrangência dos promotores do Plano para os alunos que formam a base do futuro das sociedades.

A principal função do trabalho com o tema Meio Ambiente é contribuir para a formação de cidadãos conscientes, aptos a decidir e a atuar na realidade socioambiental de modo comprometido com a vida, com o bem-estar de cada um e da sociedade local e global. Para isso, é necessário que, mais do que informações e conceitos, a escola se proponha a trabalhar com atitudes, com formação de valores, com o ensino e a aprendizagem de habilidades e procedimentos. Esse é um grande desafio para a educação já que comportamentos "ambientalmente corretos" serão aprendidos na prática do dia-a-dia na escola: gestos de solidariedade, hábitos de higiene pessoal e dos diversos ambientes, participação em pequenas negociações podem ser exemplos disso.

Já Bueno (2000) ensina que educação está relacionada à instrução, ensino, polidez e cortesia. Ao se pensar em turismo, consequentemente, há a necessidade de uma reflexão sobre os processos de desenvolvimento que a atividade produz sobre os locais, visto que o ser humano é parte integrante e indissociável do meio ambiente natural e cultural no qual está inserido. 
Por outro lado, para Bizerril (2001), a Educação Ambiental (EA) recebeu, ao longo dos anos, vários conceitos e abordagens (Sauvè 1999), citado por Bizerril (2001). Estas abordagens incluem desde a idéia de que a EA está estritamente ligada ao ensino de ciências ambientais à percepção de que a EA é simplesmente uma nova educação com discurso progressista (Mininni 1994), citado por Bizerril (2001). Na conferência de Tblisi (1997), a EA foi definida como "uma dimensão dada ao conteúdo e à prática da educação, orientada para a resolução dos problemas concretos do meio ambiente através de enfoques interdisciplinres e de uma participação ativa e responsável de cada indivíduo e da coletividade" (Dias 1993), também citado por Bizerril (2001).

Ainda de acordo com Bizerril (2001), nas décadas de oitenta e noventa, passaram a ser criticadas algumas caracterísitcas da EA, adquiridas especialmente na América do Norte, Europa e Austrália, que eram o forte vínculo com a população infantil e com a educação formal e o enfoque demasiadamente centrado na conservação da natureza (González Gaudiano 1999), citado por Bizerril (2001).

Assim, particularmente na América Latina foi impresso um enfoque mais voltado para a educação de adultos e a educação popular, associando a questão ambiental às problemáticas econômicas e padrões socioculturais específicos (Viezzer \& Ovalles 1995), citado por Bizeril (2001). Uma proposta de educação alternativa às ligadas ao conceito do desenvolvimento sustentável é a de "educação para o desenvolvimento de sociedades responsáveis", que adota uma ética da responsabilidade e considera como um dos principais aspectos da crise atual a ruptura de certo modo a conceitos de educação ambiental discutidos na década de oitenta, como o de Villaverde (1998), citado por Bizerril (2001) que considerava a educação ambiental antes de tudo um movimento ético, para a partir daí constituirse em uma renovação conceitual e metodológica dos sistemas de ensinoaprendizagem.

Bizerril (2001) destacou também os seguintes objetivos a serem atingidos pela EA:

- Contribuir para a formação de uma consciência sobre a importância da preservação da qualidade do meio ambiente em sua relação com 0 desenvolvimento, considerando os aspectos socioculturais, econômicos, políticos, científicos, tecnológicos e éticos; 
- Favorecer a aquisição de conhecimentos, valores, comportamentos e habilidades práticas a partir da reorientação e articulação das diversas disciplinas e experiências educativas, para a participação responsável e eficaz na preservação e solução dos prolemas ambientais e da gestão da qualidade do meio ambiente;

- Facilitar a percepção integrada do meio ambiente, tornando possível uma ação mais crítica que identifique as causas e não apenas seus efietos; e

- Induzir novas formas de conduta, nos indivíduos e na sociedade, a respeito do meio ambiente.

De outro modo, relacionar turismo com o desenvolvimento implica analisar mais do que o simples crescimento econômico, pois envolve o deslocamento de pessoas para lugares onde, normalmente, moram pessoas e as mais variadas relações interpessoais decorrentes desses deslocamentos. Dificilmente não ouvimos alguma coisa quanto ao respeito e ao cuidado que deveremos ter com a natureza. $O$ meio ambiente está na nossa agenda.

Não é difícil, hoje, percebermos a importância da cautela no uso dos recursos naturais, agora, já sabidamente finitos. Mas, em se tratando de sustentabilidade, o que poderíamos acrescentar a isto? Se voltarmos às nossas necessidades, facilmente, perceberemos que para satisfazê-las é preciso muito mais que "apenas" o ambiente ecológico.

Brasileiro (2008) enfatiza com muita precisão que os estragos que nós seres humanos causamos à biosfera podem impedir nossa sobrevivência e que mesmo assim, os componentes físicos do planeta poderão persistir, pois certamente haverá possibilidade de microorganismos sobreviverem e se adaptarem às novas condições. Logo, o que se discute é a presença humana na terra - a consciência animal que "dá nome às coisas". Não é possível desconhecermos, viver sem nos darmos conta de que pertencemos à natureza de que dispomos, de que somos essa natureza.

"A ciência pós-moderna nasce com a insatisfação da ciência tradicional e racionalista, cuja preocupação primeira era com o econômico em detrimento do humano. Nasce uma nova forma de pensar e se viver o mundo no turismo - a globalização, a desterritorialização, o fortalecimento da mídia, a valorização das emoções, dos sentimentos e a necessidade de realçar as experiências humanas."(Costa, 2008, pág.14) 
No citado texto também foi demonstrado que a preocupação com a natureza e com o meio ambiente surgiu no seio da sociedade pós-moderna que, ao alargar a consciência da interdependência global, gestou uma consciência holística de defesa do meio-ambiente onde a discussão sobre desenvolvimento e sobre pósmodernidade trouxe a idéia de desenvolvimento sustentável.

Assim, muitos tem sido os trabalhos e, mesmo, políticas públicas ou privadas, voltados para o desenvolvimento sustentável - ou seja - para ações visando à geração de emprego e renda, à formatação de produtos industriais e tecnológicos que estejam abrigados ou contidos em metodologias menos agressivas, menos poluidoras. É fato que temos, sim, pensado nessa perspectiva ou nessa ótica. No entanto, o processo de globalização, do qual ninguém escapa - nem as nações desenvolvidas, nem as em desenvolvimento - tem gerado impactos e, até, conduzido a paradoxos que precisamos levar em conta. Temos um desafio permanente.

Quanto aos aspectos ambiental, ecológico ou natural, as paisagens constituem atrativos para o turismo e são consideradas ativos. Os impactos que as atividades turísticas podem causar a esses atrativos são facilmente notados - sejam eles positivos ou negativos, pois se quisermos que algo seja sustentável, que dure por mais tempo do que o esperado não poderemos esquecer (ou negligenciar) das inter-relações, das associações, dos impactos e das influências mútuas que as ações causam uma às outras. Não é possível analisar e agir apenas sob um ângulo de visão. O todo é importante, é essencial e a ética da solidariedade, da busca pela justiça e equidade traz um desenvolvimento ecologicamente sustentável prudente, socialmente justo e economicamente viável. Trata-se de um compromisso com o futuro. Quem está comprometido com a sustentabilidade não pensa e age apenas para si - mas para o coletivo, para a sociedade, para a comunidade, hoje e no futuro. Encontrar a melhor relação entre o meio ambiente, a educação ambiental e o turismo sustentável e aplicá-la ao ensino fundamental através de instrumentos e métodos legais é o grande desafio dos educadores. 


\subsection{0 - As Características do Meio Ambiente e o Bioma Cerrado}

Como o tema do estudo está relacionado ao ensino no Distrito Federal, tornase fundamental conhecer o meio em que a região está inserida. Desta forma, ganha ênfase as características e os tipos de turismo voltados ao bioma cerrado e à cidade de Brasília sob a perspectiva da sustentabilidade.

Fritjof Capra14, na sua fala em um evento organizado pela Itaipu Binacional em 2004, disse que "não há como promover um desenvolvimento sustentável senão adaptado a cada bioma". Portanto, buscar os caminhos do desenvolvimento no mundo de hoje exige, pressupõe que conheçamos o bioma onde vivemos.

O Instituo Brasileiro de Geografia e Estatística - IBGE define que a formação do conceito de bioma se deu no início do século passado, como parte da ecologia dinâmica, no que se refere aos estudos de sucessão, formação, clímax e bioecologia, no contexto da busca de uma abordagem do conjunto planta-animal. Nesse processo chegou-se à formulação de que o bioma, ou formação plantaanimal, é "a unidade básica da comunidade e seria composto de plantas com os animais incluídos".

Outra constatação foi de que "na biosfera, os organismos formam comunidades relacionadas com seu ambiente através da troca de energia e matéria e desta forma, um tipo mais abrangente de comunidade reconhecido por sua fisionomia seria um bioma". No Brasil, com a disseminação do conceito da biodiversidade e visando ressaltar a riqueza biológica e genética, o bioma tem estado sempre associado ao conceito de conservação e sua visualização vem sendo buscada através da agregação dos ecossistemas por proximidade e regionalização.

Mediante tais considerações, bioma, palavra derivada do grego bio - vida, e oma - sufixo que pressupõe generalização (grupo, conjunto), deve ser entendido como a "unidade biótica de maior extensão geográfica, compreendendo várias comunidades em diferentes estágios de evolução, porém denominada de acordo com o tipo de vegetação dominante". Assim, na configuração do Mapa de Biomas do Brasil, o conceito leva ao entendimento de que um bioma:

\footnotetext{
14 - Fritjof Capra - Cientista, ambientalista, educador e ativista, Capra ficou mundialmente conhecido nos anos 70 , com a publicação do livro O Tao da Física, no qual o autor discorre sobre os paralelos entre a física quântica e o misticismo oriental. Ele vive em Berkeley, na Califórnia, onde fundou o Center for Ecoliteracy, uma instituição que forma profissionais para ensinar ecologia nas escolas. Ele é também professor do Schumacher College, um centro de estudos ecológicos na Inglaterra. O físico austríaco Fritjof Capra participou em Curitiba (PR), no dia 21 de outubro de 2004 do seminário "Humanização do Desenvolvimento Mundial", uma iniciativa do CREA-PR - Conselho Regional de Engenharia, Arquitetura e Agronomia/PR.
} 
- constitui um conjunto de tipos de vegetação, identificável em escala regional, com suas floras e faunas associadas;

- é definido pelas condições físicas predominantes, sejam climáticas, fitológicas, geomorfológicas, pedológicas, assim como uma história evolutiva compartilhada; e - é dotado de diversidade biológica singular.

Como resultado, conceitua-se bioma como um conjunto de vida (vegetal e animal) constituído pelo grupamento de tipos de vegetação contíguos e identificáveis em escala regional, com condições geoclimáticas similares e história compartilhada de mudanças resultando em uma diversidade biológica própria. Em outras palavras, "um bioma é formado por todos os seres vivos de uma determinada região, cuja vegetação tem bastante similaridade e continuidade, com um clima mais ou menos uniforme, tendo uma história comum em sua formação. Por isso tudo sua diversidade biológica também é muito parecida".

Como o estudo está focado no Distrito Federal (Região Centro Oeste) buscou-se maiores informações especificamente sobre o Bioma Cerrado, que é o mais antigo bioma brasileiro. Fala-se que sua idade é de aproximadamente 65 milhões de anos. É tão velho que $70 \%$ de sua biomassa está dentro da terra. Por isso, se diz que é uma "floresta de cabeça prá baixo" e é ainda a grande caixa d'água brasileira. É do Planalto Central que se alimentam bacias hidrográficas que correm para o sul, para o norte, para o oeste e para o leste.

\subsection{1 - O Bioma Cerrado}

Figura 4 - Biomas do Brasil

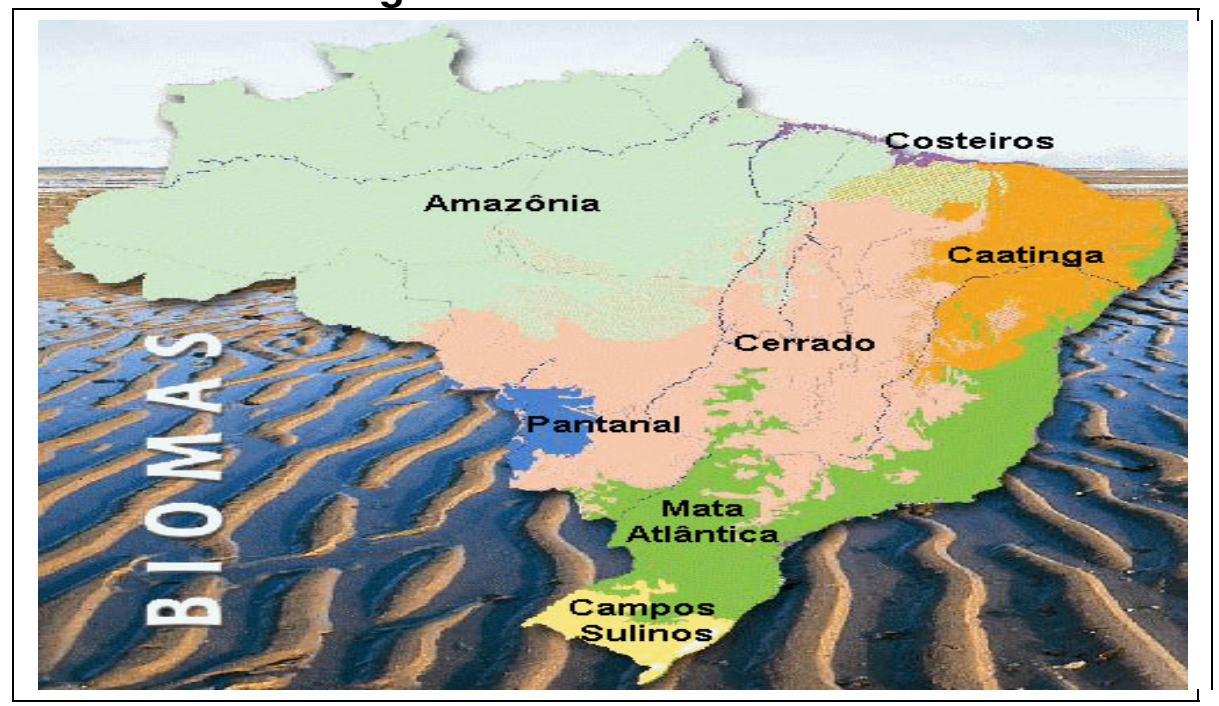


A Figura 4 apresenta os biomas brasileiros, correlacionados com as cores do Quadro a seguir:

\begin{tabular}{|c|c|c|}
\hline Biomas Continentais Brasileiros & $\begin{array}{c}\text { Área Aproximada do Territótio } \\
\left(\mathrm{km}^{2}\right)\end{array}$ & $\begin{array}{c}\text { Área/Total do } \\
\text { Brasil }\end{array}$ \\
\hline Bioma AMAZÔNIA & 4.196 .943 & $49,29 \%$ \\
\hline Bioma CERRADO & 2.036 .448 & $23,92 \%$ \\
\hline Bioma MATA ATLÂNTICA & 1.110 .182 & $13,04 \%$ \\
\hline Bioma CAATINGA & 844.453 & $9,92 \%$ \\
\hline Bioma CAMPOS SULINOS & 176.496 & $2,07 \%$ \\
\hline Bioma PANTANAL & 150.355 & $1,76 \%$ \\
\hline Bioma COSTA ATLÂNTIDA & Águas Litorâneas & -- \\
\hline Área Total Brasil & 8.514 .877 & $100,00 \%$ \\
\hline
\end{tabular}

Fonte: http://www.ibge.com.br/home/presidencia

O cerrado guarda ainda uma fantástica biodiversidade, porém, $57 \%$ de sua área já foi totalmente devasta e a metade do que resta está muito danificada. Sua devastação é muito veloz, chegando a três milhões de hectares por ano. Nesse ritmo, estima-se que em 30 anos já não existirá. A devastação de sua cobertura vegetal está comprometendo suas nascentes, rios e riachos. Ao se eliminar a vegetação, também se está eliminando os mananciais. Um rio como o São Francisco tem $80 \%$ de suas águas com origem no cerrado. Hoje se fala que é necessário uma moratória para se preservar o que resta do cerrado.

De acordo com os estudos de Bizerril (2001), dados indicam que de modo geral o cerrado é pouco discutido nas escolas do DF, resultando em estudantes pouco identificados com o bioma, apesar da ameaça de destruição. Ele observou que o cerrado e a educação ambiental de um modo geral, não são temas tratados de maneira transversal no ensino fundamental no DF, pois são abordados na maioria das escolas quase que exclusivamente em duas séries ( $5^{\underline{a}}$ e $6^{\underline{a}}$ ) e por duas disciplinas (geografia e ciências).

Para Bizerril (2001), esse bioma é tratado de modo sucinto e descritivo. Pouco é analisado em relação aos impactos negativos causados por determinadas ações antrópicas e à diversidade biológica e cultural do bioma. Tampouco as ações visando à formação de atitudes positivas em relação a ele e a abordagem interdisciplinar fazem parte da rotina das escolas da região. Além disso, os livros didáticos de ciências e geografia reforçam o tratamento do tema de modo estanque, analisando o cerrado de modo distante da realidade dos estudantes, desconsiderando aspectos socioculturais importantes. Eles, por sua vez, apresentaram preferências por paisagens e animais urbanos em detrimento da flora e fauna nativas do cerrado, fato possivelmente associados aos baixos níveis de informação e experiência afetiva anterior ao bioma. 
Bizerril (2001) enfatiza que o cerrado ainda precisa ser melhor conhecido pela ciência, embora seja inegável a significativa atenção que este bioma tem recebido por parte dos pesquisadores nos últimos anos e que os conhecimentos adquiridos sobre a biodiversidade e os processos naturais relacionados ao cerrado têm sido frequentemente divulgados em uma série de encontros científicos, mas que é questionável se estes novos conhecimentos tem sido difundidos adequadamente à população leiga e tem-se incorporado às políticas de desenvolvimento da região e que uma das ferramentas fundamentais nesse processo é a educação, que apresenta-se como forte aliada à sua conservação.

De acordo com a Secretaria do Meio Ambiente e Tecnologia/SEMATEC, o território do DF está localizado entre os paralelos de 1530' e 16ํ3' de latitude Sul e

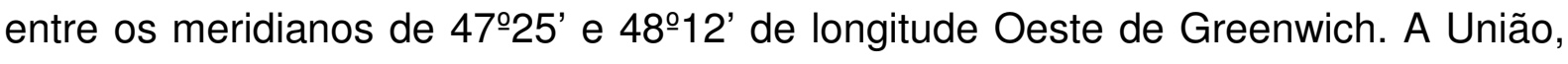
com base nos estudos técnicos-científicos realizados pela Comissão Crulz15, demarcou definitivamente, em treze de abril de 1955, a nova capital do País e os seus limites. O clima do DF é tropical com concentração de chuvas no verão, em novembro, dezembro e janeiro e período de seca ocorre nos meses de inverno, entre junho e agosto e as suas diferenças altimétricas permitem a ocorrência de três tipos climáticos: Tropical, Tropical de Altitude e Tropical de Altitute II.

Sardinha (2006) lembra que a área do DF possui aspectos geomorfológicos formados por paisagens naturais que compõem três tipos de macrounidades da região do Cerrado: região de chapada, área de dissecação intermediária e região dissecada de vale. A região de chapada é uma macrounidade que ocupa aproximadamente $34 \%$ da área e possui coberturas de Latossolos Vermelhos. Essa região pode ser caracterizada pela topografia plana suavemente ondulada, com cota acima de $1.000 \mathrm{~m}$ onde se destaca a Chapada da Contagem; a macrounidade de área de dissecação intermediária ocupa cerca de $31 \%$ da região e corresponde às áreas fracamente dissecadas, drenadas por pequenos córregos como a depressão do Paranoá e o Vale do Rio Preto; a região dissecada de vale está situada ao longo dos principais rios do DF (Descoberto, São Bartolomeu e Maranhão) e ocupa aproximadamente $35 \%$ da área. 
Em relação à pedologia, os solos do DF são similares aos solos da região do Cerrado e a Empresa Brasileira de Pesquisa Agropecuária - EMBRAPA identificou três classes principais de solos, denominadas de Latossolo Vermelho-Escuro (LE), Latossolo Vermelho-Amarelo (LV) e Cambissolo (Cb) os quais em conjunto correspondem a $85,49 \%$ do território do DF.

O autor, Sardinha (2006), relata a existência de alguns projetos de Educação Ambiental - EA voltados para o ensino fundamental no DF (por exemplo: Jaburu, Agenda 21 nas Escolas e Agentes Ambientais desenvolvidos pela Secretaria de Meio Ambiente e Tecnologia - SEMATEC; e a Escola da Natureza, que é o único de EA da Secretaria de Educação do DF), mas que, apesar de bastante importantes, todavia, são iniciativas e esforços pontuais, atingindo um público relativamente pequeno e por um tempo determinado, de modo que o Cerrado assume um caráter episódico na vida dos estudantes, fato que deveria chamar a atenção dos educadores quanto à elaboração de planos mais robustos sobre o bioma e sua sustentabilidade.

Diante disso, a proposta do estudo é inserir o tema de sustentabilidade no turismo como parte do Tema Transversal do nas Orientações Curriculares do Meio Ambiente, objetivando aprimorar os conceitos à realidade atual. No caso específico deste estudo - focalizado no DF, esta inserção pode-se dar facilmente dentro de temas relacionados ao bioma e ao turismo, especificamente ao cerrado e a Brasília.

\subsection{1 - O Turismo Sustentável no DF}

\subsection{1 - A Política de Turismo do DF}

De acordo com o Ministério do Meio Ambiente, o Governo do Distrito Federal tem sua política de turismo baseada nos pressupostos e nas diretrizes para 0 desenvolvimento da atividade turística, referenciada pelo Plano Plurianual, cujos objetivos consistem em:

- Organizar ações do governo em programas alinhados às suas orientações, que atendam às demandas da sociedade;

- Alocar recursos nos orçamentos de forma compatível com os objetivos e as diretrizes do Plano;

- Melhorar o desempenho gerencial da administração pública;

- Estimular as parcerias internas e externas para diversificar as fontes de recursos; 
- Criar condições para melhoria dos bens e serviços públicos;

- Avaliar o desempenho dos programas em relação às metas e objetivos estabelecidos; e

- Dar maior transparência aos processos da gestão pública.

O Ministério do Meio Ambiente cita também que as diretrizes norteadoras do Plano Plurianual estão estabelecidas em quatro agendas: Agenda Social; Agenda de Desenvolvimento Econômico; Agenda de Infra-Estrutura; e Agenda de Gestão Pública.

A atividade turística, por ser multifacetada, relaciona-se com as ações de todas estas agendas, de acordo com a percepção do Governo do Distrito Federal. O Plano recomenda que seja desenvolvida uma Política para o Distrito Federal, já que a atividade turística é considerada uma importante geradora de empregos e define como estratégias o que segue:

- Complementar a infra-estrutura turística de Brasília;

- Divulgar a imagem do Distrito Federal, em âmbitos nacional e internacional;

- Formular alternativas de crescimento do setor de turismo, estabelecendo metas e estratégias, de curto, médio e longo prazos; e

- Realizar articulações com estados e municípios da área de influência de Brasília a fim de implementar políticas comuns e harmônicas para o desenvolvimento do turismo.

Para a Brasiliatur - Empresa Brasiliense de Turismo - Órgão do governo do Distrito Federal, o turismo cívico tem potencial para contribuir na promoção da justiça social e na consolidação da democracia, envolvendo o cidadão, o estado e o setor produtivo. Ele se apresenta como ferramenta de inclusão social capaz de promover a conscientização cidadã, política, econômica e cultural dos visitantes que o praticam, promovendo, desta forma, o patriotismo. Em Brasília a sua aplicabilidade está relacionada às atrações cívicas (templos, museus, palácios, parques), além do ecoturismo e do turismo rural que necessitam de maior apoio por parte do Governo local. 


\subsection{2 - O Potencial Turístico de Brasília}

Brasília/DF localiza-se na região central do Brasil - verdadeiro coração do País - dentro do Estado de Goiás. E não foi formada ao acaso. Destaca-se, em todo o mundo, pela aplicação dos princípios da Carta de Atenas16 - integrada a uma estratégia de desenvolvimento e auto-afirmação nacional.

O grande atrativo da cidade é o turismo cívico. Num passeio pela Praça dos Três Poderes, é possível conhecer os locais de onde emana a maioria das decisões políticas: Congresso Nacional, Supremo Tribunal Federal, Palácio do Planalto, Esplanada dos Ministérios, Palácio do Itamaraty e Palácio da Justiça se misturam aos monumentos e obras de renomados artistas. Mas nem só de turismo cívico vive o Distrito Federal. Quem passar pela região pode encontrar belíssimas opções de passeios ecoturísticos: mais de 72 parques, como o Jardim Botânico, o Parque Nacional de Brasília, a Estação Ecológica de Águas Emendadas (reserva que se encontram as nascentes dos cursos d'água que formam a Bacia Amazônica e a Bacia do Prata), as cachoeiras de Mumunhas, Poço Azul, Saia Velha e Tororó, com trilhas acessíveis até para quem não é perito em aventura, além do turismo rural que ganha destaque cada vez maior.

\subsection{3 - O Turismo Cívico em Brasília}

Em 1956, o então Presidente Juscelino Kubitschek deu início à construção da nova Capital Federal. Milhares de trabalhadores, vindos de todos os cantos do País, concentraram-se na região, construindo não só a cidade que seria o centro do poder no País, mas também dando forma às terras que hoje conhecemos como Distrito Federal. Brasília nasceu do projeto urbanístico de Lúcio Costa e localiza-se em meio ao cerrado brasileiro, um dos ecossistemas mais ricos do país.

Por sua beleza arquitetônica, Brasília foi tombada, em 1987, como Patrimônio Histórico e Cultural da Humanidade, sendo a única cidade criada no século $X X$ a receber esse título. O Plano Piloto tem a forma de um avião, com eixo central e asas. Quem circula pela região percebe sua divisão em setores bem definidos, as amplas avenidas e muitas árvores, por todos os lados.

16 - Em 1943, o IV Congresso Internacional de Arquitetura Moderna (IV CIAM) apresentou como resultado de sua reunião, realizada em Atenas/Grécia, um documento que entrou para a história do século XX com o nome de "Carta de Atenas", dedicando interesse objetivo sobre questões relacionadas ao patrimônio histórico e à conservação e preservação, tanto de monumentos quanto no que se relaciona à cidade como um todo. 
O Lago Paranoá, criado para amenizar a baixa umidade em determinadas épocas do ano, além de proporcionar uma bela vista, também é uma excelente opção para a prática de esportes náuticos e para o lazer.

\subsubsection{1 - Principais Atrações Cívicas de Brasília}

\section{Igrejas:}

- Catedral Metropolitana de Brasília: projetada por Oscar Niemeyer, foi inaugurada em 1970. Tem formato circular e é constituída por 16 pilares curvos entremeados por belíssimos vitrais, criados por Marianne Peretti - sua disposição garante iluminação natural à nave, que fica abaixo do nível do solo.

- Santuário Dom Bosco: é cercado por arcos que sustentam imensos vitrais com várias tonalidades de azul. Entremeados por pontos mais claros, dão a impressão de céu estrelado e de mudar de lugar conforme a posição do sol. O lustre central contém 7.400 copos de vidro Murano. O Santuário foi inaugurado em 1963.

- Templo da Legião da Boa Vontade: aberto 24 horas, a construção em forma de pirâmide tem o piso decorado com espirais em granito. No topo do templo, uma pedra de cristal de $40 \mathrm{~cm}$ e $21 \mathrm{~kg}$ confere energia positiva ao local, segundo os idealizadores da obra. Localiza-se na Quadra 915 Sul.

\section{Museus:}

- Museu de Valores do Banco Central: exposição permanente de moedas e cédulas nacionais e estrangeiras. Tem também uma exposição sobre extração de ouro que exibe a maior pepita encontrada no Brasil, com $62 \mathrm{~kg}$.

- Memorial JK: em destaque no Eixo Monumental, é uma homenagem ao idealizador e fundador de Brasília, o Presidente Juscelino Kubitschek. Nos salões encontram-se o museu - com fotos, documentos e objetos referentes à vida de JK e a Câmara Mortuária, com o túmulo do ex-presidente.

- Museu Nacional de Gemas: mostra permanente de pedras e cristais brasileiros. Fica no Salão Panorâmico da Torre de TV, no Eixo Monumental.

- Centro Cultural Banco do Brasil - CCBB: abriga exposições temporárias, mostras de arte e espetáculos teatrais e de dança. Também possui lanchonete, loja de suvenires e auditório, onde são promovidos debates sobre os mais diversos assuntos, rodas de leitura, entre outros eventos. 
- Museu da Imprensa: o grande destaque desse museu é o prelo usado pelo famoso escritor brasileiro, Machado de Assis, que exerceu a profissão de gráfico na sua juventude. Há também exemplares do Diário Oficial em que foram publicadas a Lei Áurea e o Ato de Proclamação da República.

- Memorial dos Povos Indígenas: apresenta peças indígenas utilitárias - como cerâmicas, vasos e redes - e ritualísticas - cocares e colares - das tribos de todo o país.

\section{Passeios:}

- Catetinho: primeira construção de Brasília, erguida em 1956, quando a capital ainda nem estava pronta - servia de residência oficial ao então Presidente da República Juscelino Kubitschek. Lá podem ser observados móveis e objetos da época, utilizados nos primeiros passos de Brasília como capital federal.

- Torre de Televisão: projeto de Lúcio Costa, com 224 m de altura, é local de visita obrigatória na cidade. Lá de cima pode-se avistar boa parte do Plano Piloto, a partir de uma plataforma a $75 \mathrm{~m}$ do chão, que tem capacidade para 150 pessoas. Circundando a Torre está instalada a maior e mais tradicional feira de artesanato de Brasília. A Torre de TV fica no Eixo Monumental.

- Palácio da Alvorada: residência oficial do Presidente da República. No meio de um enorme jardim, fica o prédio conhecido por suas colunas de mármore branco que se tornaram símbolo de Brasília - projeto de Oscar Niemeyer. Primeira grande construção erguida na cidade foi inaugurado, antes de Brasília ficar pronta, em 1958.

- Praça dos Três Poderes: a Praça abriga alguns dos prédios mais significativos da obra de Oscar Niemeyer - o Palácio do Planalto, sede da Presidência da República; o Congresso Nacional, sede da Câmara dos Deputados e do Senado Federal; e o Supremo Tribunal Federal. Na praça central uma Bandeira Nacional de $286 \mathrm{~m}$ quadrados é sustentada por um mastro de $100 \mathrm{~m}$ de altura.

- Congresso Nacional: sede do Poder Legislativo, o Congresso Nacional é composto pelo Senado Federal - que fica do lado esquerdo e é representado pelo "prato côncavo" - e pela Câmara dos Deputados - localizada ao lado direito e representada pelo "prato convexo".

- Palácio do Planalto: sede do Poder Executivo e local de trabalho do Presidente da República. Uma atração à parte é a troca da guarda do Palácio do Planalto, que acontece a cada duas horas - sendo a primeira às $8 \mathrm{~h}$, e a última do dia, às $18 \mathrm{~h}$. 
- Palácio do Itamarati: também conhecido como Palácio dos Arcos, o Palácio do Itamarati abriga diversas obras de arte e antiguidades.

- Supremo Tribunal Federal: sede do Poder Judiciário do País, o Supremo abriga uma biblioteca com aproximadamente 80 mil volumes.

- Palácio da Justiça (Ministério da Justiça): sede do Ministério da Justiça oferece visitas guiadas ao Salão Negro, Sala de Retratos, Biblioteca e Jardim Interno.

- Panteão da Pátria Tancredo Neves: monumento à liberdade e à democracia, homenageia os heróis da pátria e o ex-presidente Tancredo Neves. O projeto é de Oscar Niemeyer e possui acervo de vários artistas.

- Espaço Lúcio Costa: espaço dedicado à maquete da cidade de Brasília. Fica no subsolo da Praça dos Três Poderes - ao final da Esplanada dos Ministérios.

- Ponte JK: inaugurada em 2002, a Ponte JK é a terceira ponte construída para ligar o Plano Piloto ao Lago Sul. É considerada uma das pontes mais belas do mundo.

\subsection{4 - O Ecoturismo em Brasília e Entorno}

De acordo com o Ministério do Turismo, O Brasil vem ganhando destaque internacional no ramo do turismo de negócios e viagens de incentivo, promovidas por grandes empresas de todo o mundo. Tem sido um dos destinos mais escolhidos para sediar feiras, congressos, convenções ou exposições de todos os tipos. É fácil entender o motivo disso: além de possuir estrutura adequada para abrigar eventos, o País ainda pode oferecer as mais variadas opções de lazer cultural, natural e artístico, unindo o útil ao agradável.

Já para o Ministério do Meio Ambiente, o Programa Nacional de Ecoturismo estabelece os critérios para a atuação nas áreas protegidas, abrangendo as diversas categorias de unidades de conservação, para enfrentar os desafios da relação conservação e uso sustentável, a partir dos temas estratégicos definidos na Agenda 21 Brasileira: a economia da poupança na sociedade do conhecimento; a inclusão social por uma sociedade solidária; a estratégia para sustentabilidade urbana e rural; os recursos naturais estratégicos - água, biodiversidade e florestas, e a governança e a ética para a promoção da sustentabilidade. 
Atualmente, a caminhada ecológica é a atividade mais praticada em todo 0 mundo no ramo do ecoturismo. Neste cenário, o Brasil destaca-se por oferecer variados roteiros ligados à natureza e voltados à conscientização e preservação do meio ambiente, com passeios repletos de trilhas.

O cerrado da Região Centro-Oeste, por sua vez, abriga vários Parques Nacionais, como a Chapada dos Guimarães, no Estado do Mato Grosso; o Parque Nacional de Brasília e a Estação Ecológica de Águas Emendadas na região da capital federal, repleto de deliciosas piscinas naturais e reservas de água doce; a Chapada dos Veadeiros e o Parque Nacional das Emas, no Estado do Goiás, inscritos na lista de Patrimônios Naturais da Humanidade.

O ecoturismo pode ser dividido em etapas: flutuação (mergulho); observação de fauna, flora, riquezas hídricas e aves; e espeologia (exploração de cavernas).

A flutuação é uma modalidade de mergulho leve, de pequena profundidade, em que a diversão se faz apenas com um snorkel (equipamento de mergulho para respiração) e uma máscara - dependendo do lugar, nadadeiras e lanterna também podem fazer parte dos apetrechos necessários. Não há registro dessa modalidade de ecoturismo no Distrito Federal. No Brasil, um dos locais mais conhecidos e procurados pelos praticantes da flutuação é a cidade de Bonito, no Estado do Mato Grosso do Sul.

Várias formas de lazer vêm surgindo nos últimos anos, estimuladas pela crescente conscientização ambiental. O interesse pela observação da fauna silvestre é um exemplo claro disso. Hoje, turistas de todo o mundo viajam longas distâncias somente para ter a chance de conhecer de perto a vida selvagem. Para eles, nada melhor do que vir ao Brasil. As áreas de proteção ambiental representam hoje cerca de $5 \%$ do território nacional. A Região Centro-Oeste é um bom começo para quem quer conhecer animais brasileiros e no Distrito Federal destaca-se o Parque Nacional de Brasília, a popular "Água Mineral”.

Já a observação de aves é um passatempo praticado por milhões de pessoas em todo o mundo. São turistas que saem de seus países atraídos pelo desafio de avistar e identificar espécies exóticas de pássaros. Com florestas tropicais exuberantes, o Brasil oferece condições excepcionais para os observadores de aves e ornitólogos, estudiosos cuja área de interesse são os pássaros. O País abriga aproximadamente 1.677 espécies de aves, quase 18\% da diversidade mundial de pássaros. No coração do Brasil, a Região Centro-Oeste oferece boas oportunidades 
para os observadores de pássaros. Entre elas estão o Parque Nacional do Pantanal Mato-grossense, o Parque Nacional das Emas e a Chapada dos Veadeiros, no Estado de Goiás, e no Distrito Federal o Parque Nacional de Brasília, a Estação Ecológica de Águas Emendadas e o Jardim Botânico.

As cavernas e grutas fascinam o homem desde sempre. Suas formações geológicas seduzem o olhar pela diversidade, complexidade e pelo tempo que a natureza investiu nelas - são milhares de anos até que adquiram a forma como as conhecemos hoje. O turismo de cavernas - ou espeleoturismo - consiste justamente em explorar e conhecer o interior dessas fantásticas formações. Como em todo o mundo, o interesse pelo espeleoturismo no Brasil tem crescido bastante. Isto se deve ao aperfeiçoamento técnico desenvolvido nas unidades de conservação do País nos últimos anos. São cerca de 2.800 cavernas cadastradas, segundo a Sociedade Brasileira de Espeleologia, embora a instituição reconheça que esse número seja bem superior. Deste total, 53 são consideradas turísticas. No CentroOeste brasileiro também há boas cavernas e grutas para se visitar. No Estado do Mato Grosso, vale a pena conhecer o Parque Nacional da Chapada dos Guimarães. No Estado do Mato Grosso do Sul, a atração é a cidade de Bonito, que abriga as famosas grutas de São Miguel e a Gruta do Lago Azul. No Distrito Federal a atividade vem ganhando força nos últimos anos e as escolas promovem passeios e excursões para a região do entorno, especialmente em Corumbá e Planaltina de Goiás.

\subsubsection{1 - Parques do Distrito Federal}

De acordo com o IBRAM, A Capital Federal possui parte de seu território sob alguma forma de proteção ambiental e conta com 72 parques criados por decretos, cuja maioria ainda não foi totalmente implantada nem possui equipamentos que proporcionem opções de lazer ou visitação e aqueles em funcionamento têm uma gestão precária e necessitam de melhorias, mas que podem contribuir com 0 aprendizado descentralizado, de acordo com as necessidade de cada RA. São eles:

- Águas Claras: Ecológico Águas Claras.

- Brasília: Ecológico Burle Marx (Ecológico Norte), Parque Ecológico e de Uso Múltiplo Olhos D’Água, Parque das Aves, De Uso Múltiplo da Asa Sul, De Uso Múltiplo Vila Planalto e De Uso Múltiplo da Enseada Norte (Parque Enseada). 
- Brazlândia: Parque Ecológico Veredinha.

- Candangolândia: Ecológico e Vivencial da Candangolândia e Pioneiros.

- Ceilândia: Ecológico e Vivencial do Rio Descoberto, Recreativo do Setor "O", Lagoinha, Corujas e Uso Múltiplo Metropolitano (Parque Ecológico Metropolitano).

- Gama: Recreativo do Gama (Municipal do Gama - Prainha), Parque de Uso Múltiplo Ponte Alta do Gama e Urbano e Vivencial do Gama

- Guará: Ecológico Ezechias Heringer (Parque do Guará), Vivencial Denner e Parque Ecológico e Vivencial Bosque dos Eucaliptos.

- Lago Norte: Uso Múltiplo do Lago Norte (RA Lago Norte), De Uso Múltiplo Morro do Careca (Parque Morro do Careca), Ecológico das Garças e Ecológico do Taquari.

- Lago Sul: Parque das Copaíbas, Ecológico e Vivencial Canjerana, Ecológico Garça Branca, Vivencial do Anfiteatro Natural do Lago Sul, Ecológico Dom Bosco, Ecológico Bernardo Sayão (Ecológico do Rasgado) e Ecológico Península Sul.

- Núcleo Bandeirante: Recreativo do Núcleo Bandeirante, Ecológico Corrego da Onça, Ecológico Lauro Müller e Ecológico Luiz Cruls.

- Paranoá: Parque Urbano do Paranoá, Ecológico da Cachoeirinha e De Uso Múltiplo das Esculturas (Parque das Esculturas).

- Planaltina: Ecológico e Vivencial Cachoeira do Pipiripau, das Sucupiras, Ecológico e Vivencial da Lagoa Joaquim de Medeiros, Ecológico dos Pequizeiros, Ecológico do D.E.R, Ecológico e Vivencial do Retirinho, Ecológico e Vivencial Estância, Parque Ambiental Colégio Agrícola de Brasília e De Uso Múltiplo Vale do Amanhecer.

- Recanto das Emas: Ecológico e Vivencial do Recanto das Emas.

- Riacho Fundo: Ecológico e Vivencial do Riacho Fundo.

- Samambaia: Parque Três Meninas e Parque Ecológico Gatumé.

- Santa Maria: Recreativo de Santa Maria e Ecológico do Tororó.

- São Sebastião: São Sebastião.

- Sobradinho: Parque dos Jequitibás, Recreativo e Ecológico Canela de Ema, Ecológico e Vivencial de Sobradinho, Recreativo Sobradinho II e De Uso Multiplo Centro de Lazer e Cultura Viva Sobradinho.

- Sudoeste/Octogonal: Urbano Bosque do Sudoeste e De Uso Múltiplo das Sucupiras (Parque Recreativo Sucupira).

- Taguatinga: Boca da Mata, Areal, Ecológico Saburo Onoyama, Ecológico Irmão Afonso Haus (Santuário dos Pássaros), Recreativo Taguatinga e Lago do Cortado.

- Varjão: Ecológico e Vivencial da Vila Varjão 


\subsubsection{2 - Outras Atrações do Ecoturismo em Brasília}

- Parque da Cidade - Sarah Kubitschek: dentro dos limites do Plano Piloto fica o Parque da Cidade, com quatro milhões de metros quadrados. O paisagismo é de Burle Marx e os azulejos que ornamentam os sanitários espalhados por todo 0 Parque são de Athos Bulcão.

- Jardim Botânico de Brasília: foi fundado em março de 1985 e desde então passou por várias reformas para satisfazer seus originais requisitos filosóficos - ser uma mostra do cerrado - e técnicos - tornar-se um espaço de pesquisa, educação ambiental e lazer para a população. Lá encontram-se, além da vegetação típica do cerrado, trilhas para caminhadas, um mirante e um Centro de Visitantes.

- Parque Nacional de Brasília: possui 30 mil hectares. É mais conhecido como Água Mineral - por causa de suas nascentes e piscinas de água corrente formadas a partir dos poços d'água que surgiram às margens do Córrego Acampamento. Além das piscinas naturais, há também duas trilhas para caminhada: a Trilha da Capivara, que tem 1,3 km de extensão e pode ser percorrida em 20 minutos; e a Trilha Cristal Água, que exige uma hora de caminhada por seu percurso de $5 \mathrm{~km}$. Nos dias mais tranqüilos é possível observar a fauna local, como tatus, macacos e capivaras.

- Estação Ecológica de Águas Emendadas: é uma unidade de conservação localizada na Região Administrativa de Planaltina. Localiza-se a $50 \mathrm{~km}$ da rodoviária do Plano Piloto, a nordeste de Brasília, com uma área de 10 mil 547 hectares. Dentro desta unidade de conservação nascem duas das principais bacias hidrográficas brasileiras: ao norte a bacia do Tocantins e, ao sul, a bacia do ParanáPrata. É uma unidade de conservação de proteção integral destinada à proteção do ambiente natural, realização de pesquisas básica e aplicada em ecologia e à educação conservacionista. Pelo seu excelente estado de conservação dos ecossistemas foi declarada em 1992 pela Unesco como uma das áreas que compõem a área nuclear da Reserva da Biosfera do Cerrado.

- Jardim Zoológico de Brasília: ocupa uma área de 140 hectares, ao lado do Santuário de Vida Silvestre do Riacho Fundo, com 440 hectares, e do Parque das Aves, com 110 hectares, todos geridos pela Fundação Pólo Ecológico de Brasília (FunPEB), resultando numa área total de 690 hectares. 


\subsection{5 - O Turismo Rural em Brasília e Entorno}

Para Montenegro (2001), o turismo rural é relevante para o DF, pois resulta em fatores positivos para a economia da região. Cria novas oportunidades de trabalho, fixa o homem no campo, ou próximo de sua localidade de origem, junto à sua família, permite o aparecimento de novas opções e práticas econômicas, possibilita maior remuneração aos trabalhadores do campo envolvidos com atividades em propriedades que desenvolvem o turismo no espaço rural, preserva hábitos e costumes da roça e ainda conserva o meio ambiente natural.

O autor diz ainda que o sucesso do turismo em espaço rural está na garantia da sustentabilidade do empreendimento no que se refere aos aspectos ambiental, econômico e social, satisfazendo os princípios ecológicos de conservar o ambiente, tratar o lixo, evitar poluição, desmatamentos, queimadas predatórias e assentamentos residenciais irregulares.

Conforme Sardinha (2006), o turismo rural no DF começou a ser ordenado em 1995, quando três propriedades rurais, Fazenda Recreio Mugy, Granja Nova Cambuci (Trem da Serra) e Chácara Buriti Alegrem, pioneiras na região, isoladamente, começaram a explorar a atividade turística no espaço rural, a fim de solucionar problemas econômicos e melhorar necessidade de comercialização da produção de pequena escala, além de obter retorno mais rentável para seus produtos e serviços e melhorar o mercado de trabalho e a qualidade de vida das comunidades locais (Bravo, 2000, p.14 e Montenegro, 2001, P.60).

Atualmente, há registros de várias propriedades na Região que modificaram suas atividades, passando a atuar como "hotéis fazendas". Pode-se registrar o RM Hotel Fazenda, Hotel Fazenda Águas Emendadas e a Fazenda Hotel Mestre D’armas. Bravo (2003) acrescenta que esses proprietários procuraram aumentar os recursos da economia rural com a criação, a venda e a comercialização de produtos provenientes do campo, conciliados a uma infra-estrutura e à prestação de serviços turísticos no meio rural, visando, também, a satisfação da população urbana que procura o campo.

Sardinha (2006) lembrou que o Serviço de Apoio às Micro e Pequenas Empresas do DF (SEBRAE-DF) lançou o programa de Turismo Rural, cuja finalidade é gerar alternativa de renda para o produtor rural, aumentar o nível de empregos; melhorar a competitividade da produção rural no mercado, por meio da 
implementação do cooperativismo e associativismo; valorizar os produtos típicos e as tradições culturais do meio rural; diminuir o êxodo rural; e criar formas de lazer para as pessoas que vivem na cidade.

O SEBRAE-DF ainda realiza ações voltadas para o diagnóstico de viabilidade da implantação ou ampliação do empreendimento turístico; oferece apoio para a realização e participação em feiras e exposições; orienta empresários (abertura de empresa, linhas de financiamento disponíveis, registro de marcas e patentes, custos e formação do preço de venda); além de disponibilizar publicações com informações técnicas especializadas.

Segundo dados do SEBRAE-DF, em 2003, existiam setenta pequenas propriedades que se tornaram vitrine para o turismo rural no DF, agregando valor aos produtos do campo e gerando trabalho e renda. As opções oferecidas para os turistas vão desde restaurantes que oferecem culinária típica local ou regional a trilhas, hortifrútis orgânicos, casas de chá, hospedagem, criação de galináceos, suínos e caprinos, arquitetura histórica, utensílios na lida do homem rural e peças centenárias.

Assim, outra expectativa do estudo é mostrar que a região é rica em ambientes naturais pouco conhecidos, devido, provavelmente, à falta de informação e de um Plano Comercial de alcance aos alunos das escolas públicas e privadas e dê maior orientação ao corpo docente dessas instituições, que poderiam extrair resultados práticos e exemplos de sustentabilidade nessas localidades. 


\section{METODOLOGIA DO ESTUDO}

A revisão qualitativa do estudo do meio ambiente e a sustentabilidade do turismo e sua aplicação no Ensino Fundamental do DF baseou-se na coleta de dados e análise dos mais importantes documentos legais, além do estudo de renomados autores ligados à Educação Ambiental na região, especialmente ao bioma cerrado e à cidade de Brasília, com o objetivo de formular sugestões de temas e tópicos de ensino para municiar os professores com técnicas e ferramentas apropriadas a serem aplicadas às aulas, em condições adequadas para o ensino na rede educacional da Secretaria de Educação do DF. Dentre estes, teve-se como base os PCN's do Meio Ambiente, a Lei de Diretrizes e Bases da Educação Nacional e as Orientações Curriculares do DF.

Quanto ao cerrado, Bizerril (2001) citou que o tema poderia ser melhor discutido e analisado nas escolas do DF, dado que resulta em estudantes pouco identificados com o bioma, principalmente em relação aos impactos negativos causados por determinadas ações antrópicas e que os livros didáticos pouco colaboram aos desconsiderar aspectos socioculturais da região.

Frente às análises desses estudos e documentos, propôs-se a revisão das informações sobre o bioma cerrado e os tipos de turismo relacionados a ele, especialmente ao Distrito Federal, e a problemática para sua sustentabilidade, de modo a se poder trazer orientações para a sua abordagem no Ensino Fundamental do DF, com ênfase nas características da região voltadas para o turismo cívico, o ecoturismo, o turismo rural e suas peculiaridades.

Nesse contexto, o estudo deverá propor temas voltados à sustentabilidade associados aos conceitos básicos do turismo, através da inserção nas Orientações Curriculares do Ensino Fundamental, Séries e Anos Finais, de modo a contribuir para a proteção do meio-ambiente em que os indivíduos estão inseridos. Identificará as principais fontes de referência para a proposição de conteúdos programáticos à grade curricular específica sobre o assunto no Distrito Federal, para o que será necessário conhecer as características naturais e ambientais da região. $O$ uso de técnicas de ensino em laboratórios, aulas práticas, visitas técnicas, passeios, excursões, leitura, pesquisas em grupo e individual, recursos audiovisuais, internet, seminários e feiras serão analisados nas propostas de conteúdos pedagógicos. 


\section{RESULTADOS DO ESTUDO}

Inicialmente, os docentes deverão ser conscientizados de que - para falar de meio ambiente, sustentabilidade, turismo (cívico, rural e ecoturismo) - devem utilizar, além dos métodos tradicionais, outros conteúdos e procedimentos que transfiram seus alunos aos ambientes estudados, pois, conforme dispõe a Declaração Mundial sobre Educação para Todos, a criança e o adolescente devem poder se beneficiar de uma formação concebida para responder às suas necessidades educativas fundamentais, valores básicos para a manutenção do ser humano em seu meio ambiente, o que é um dos temas e preocupação da pesquisa.

Para tal, a atual Constituição Brasileira diz que "todos tem direito ao meio ambiente ecologicamente equilibrado, impondo-se ao poder público e à coletividade o dever de defendê-lo e preservá-lo para as futuras gerações" (art 225), daí a necessidade da participação da escola como instrumento e elo entre a sociedade e - aluno, já que é dever do Estado fixar conteúdos mínimos para o ensino Fundamental, de maneira a assegurar a formação básica comum e respeito aos nossos valores culturais e artísticos, nacionais e regionais (art 210).

Como foi visto, Faria (1997) ressaltou que a Política Nacional de Meio Ambiente (Lei no 6.398) determina que a EA seja adota em todos os níveis de ensino, embora como caráter interdisciplinar, O Parecer № 226/87 do Conselho Federal de Educação, citado por Faria (1997), recomendou a preparação adequada dos docentes para esse ensino, visando desenvolver nos alunos hábitos, atitudes e comportamentos que propiciem a formação de uma cultura ativa na defesa do meio ambiente saudável. As comunidades locais deverão ter a capacidade de repensar seu processo de desenvolvimento, corrigindo distorções e propondo inovações que garantam o desenvolvimento sem comprometer as condições ambientais.

Nesse sentido, o artigo 5o da LDB o 9.394/96 - Lei das Diretrizes e Bases da Educação Nacional - afirma que o ensino fundamental é direito público subjetivo, podendo qualquer cidadão acionar o Poder Público para exigi-lo, visando desenvolver no educando a formação indispensável para o exercício da cidadania através de meios para progressão nos estudos. Deve ter-se as referências dos Parâmetros Curriculares Nacionais - PCN's como instrumentos de ligação da educação com o meio ambiente, visando uma melhor qualificação, para o País. A aplicabilidade dos temas dessa natureza, voltados para a preservação do meio 
ambiente, possibilitam o turismo sustentável.

Considerando as necessidades de construção de referenciais nacionais comuns ao processo educativo e tendo como objeto de estudo o respeito às diversidades regionais, culturais e políticas de cada região do País, os PCN's possibilitam a criação de condições, nas escolas, que permitam aos jovens o acesso ao conjunto de conhecimentos socialmente elaborados e reconhecidos como necessários ao exercício de uma cidadania com bases sustentáveis.

Assim sendo, esta pesquisa buscou estar em harmonia com a proposta de organização do conhecimento nos PCN's do Meio Ambiente, os quais, por sua vez, estão em consonância com o Artigo 26 da LDB, que diz que os currículos do ensino fundamental devem ter uma base nacional a ser complementada por uma parte diversificada exigida pelas características regionais e locais da sociedade. Justificase, assim, mais uma vez, o estudo mais detalhado, como tema transversal, do bioma cerrado e as características do turismo sustentável no Distrito Federal pelas escolas locais.

Também, fez-se então necessário estudar as Orientações Curriculares do Ensino Fundamental da Secretaria de Educação do DF, porque, nas Orientações para proposições sobre o currículo para as instituições educacionais públicas do DF, propicia expectativas de ensino e aprendizagem para todos os anos e disciplinas do ensino fundamental. Norteia, assim, o processo pedagógico nas escolas para o Ensino Fundamental, cujas habilidades e conteúdos para os componentes curriculares e seus referenciais teóricos e metodológicos serão focos da atuação em sala de aula. Considerando as diversas formas e aprendizagens com o objetivo de preparar o aluno para o exercício da cidadania. A socialização, no espaço escolar, de conhecimentos, competências, habilidades, valores e atitudes como recurso para tomar decisões favoráveis à preservação do meio em que vivem, sejam estudantes da rede pública ou privada, é de suma importância.

Nesse sentido, Bizerril (2001) já dizia que não existe diferença significativa entre ensino público e privado quanto às técnicas empregadas de ensino, mas que existe uma tendência a maior diversificação, pelo ensino privado, especialmente quanto ao uso de pesquisas em grupo, trabalhos de campo e realização de exposições, embora a maioria desses professores considere que existam limitações para o desenvolvimento de temas como "cerrado" e "educação ambiental" nas escolas públicas do DF. 
Quanto às metodologias, Bizerril (2001), lembrando Krasilchick (1987), cita que são frequentes as críticas à qualidade do ensino oferecido pelas escolas no Brasil, que os programas são extensos e detalhistas e ministrados com um caráter essencialmente informativo, de tal modo que os componentes formativos de atitudes e valores e de estímulo à participação nas decisões comunitárias poderiam ser melhor aplicados, fato que contribuiria para uma melhor qualificação do processo nas instituições de ensino.

Faria (1997) apontou que um modo estimulante de buscar o interesse do aluno e tornar as aulas mais criativas é partir de uma questão que tenha relação com a vida do aluno, facilitando seu envolvimento pessoal e a compreensão dos fenômenos abordados, pois o tema desperta interesse no aprendizado, favorecendo especialmente o ensino de ciências.

Por outro lado, foi estudada a Conferência Intergovernamental de EA de Tbilisi que definiu princípios a serem desenvolvidos pelas escolas com destaque para o exame das principais questões ambientais do ponto de vista local, regional, nacional e internacional; a promoção da participação dos alunos na organização de suas experiências de aprendizagem, dando-Ihes a oportunidade de tomar decisões; o auxílio aos alunos quanto à descoberta de sintomas e as causas reais dos problemas ambientais $\mathrm{e}$ as suas complexidades e conseqüências para 0 desenvolvimento crítico e das atitudes para resolvê-los.

Diante disso, Bizerril (2001), reafirmando que a tarefa na elaboração dos currículos passa a ser de competência das Secretarias Regionais de Educação, conforme as diretrizes dos PCN's, cabe às escolas a formulação dos programas de ensino e a tarefa de formular seus próprios programas, possibilitando a elas a seleção de conteúdos mais relacionados com a realidade da comunidade, de modo a tornar as aulas mais atrativas aos alunos e eficientes, tanto no processo de aprendizagens específicas, como na formação de cidadãos para transformar a realidade.

Daí a oportunidade da sugestão de temas ligados à sustentabilidade no desenvolvimento do turismo no Distrito Federal. Mais do que ensinar técnicas de planejar, orientar e avaliar a aprendizagem - tendo por base modelos ou princípios de outras áreas de saber, ou construídos no interior da teoria didática - as disciplinas devem propiciar a análise crítica da realidade do ensino por parte dos professores e alunos, buscando problematizá-las e explicá-las à luz do contexto em 
que se produz, devendo-se buscar respostas ou novas perguntas às questões postas, para o que se recorre ao universo das sistematizações teóricas na área, aproximando os alunos da realidade do ensino, seja no interior das salas de aula ou em ambientes naturais, à luz das transformações que vem ocorrendo na formação social brasileira.

Nessa direção, utilizou-se a Agenda 21 para estudar os aspectos gerais relacionados ao meio ambiente como um processo participativo em que a sociedade, os governos, os setores econômicos e sociais ponham-se à mesa para diagnosticar os problemas, entender os conflitos envolvidos e pactuar formas de resolvê-los, de modo a construir o que tem sido chamado de sustentabilidade ampliada e progressiva.

Diante dessas considerações, a finalidade deste estudo foi analisar as Orientações Curriculares do Ensino Fundamental do DF, especialmente o tema de Meio Ambiente das Ciências Naturais, para:

1. Aplicação dos temas de sustentabilidade e turismo no Ensino Fundamental;

2. Integração aos planos e metodologias dos professores em salas de aula e fora delas; e

3. Propor novas técnicas de aplicação da matéria nas aulas para atender aos objetivos do estudo, relacionando-os ao meio ambiente e ao turismo sustentável e seus reflexos para a comunidade afetada pelas atividades turísticas.

\section{1 - Sugestões de Temas/Tópicos de Ensino - As Possibilidades da Inserção dos Conteúdos Relacionados ao Turismo nas Orientações Curriculares do Ensino Fundamental do DF}

Baseado nas premissas apontadas e no conteúdo do estudo foram feitas propostas de incremento de novas orientações curriculares para as séries e anos finais do ensino fundamental das ciências naturais - tema transversal do meio ambiente - para as escolas do Distrito Federal. À elas aplicam-se técnicas e ferramentas de ensino em laboratório, aulas práticas e visitas técnicas; passeios e excursões; leitura em sala de aula; pesquisas em grupo e individual, uso de recursos audiovisuais e internet; e seminários e feiras, cujos novos conteúdos e habilidades são os seguintes: 
5.1.1 - $6^{\circ} \mathrm{Ano} / 5^{\mathrm{a}}$ Série

\begin{tabular}{|c|c|c|}
\hline \multicolumn{3}{|c|}{ CIÊNCIAS NATURAIS - VIDA E AMBIENTE } \\
\hline $\begin{array}{l}\text { Conteúdos } \\
\text { Previstos }\end{array}$ & $\begin{array}{l}\text { Técnicas/Ferramentas } \\
\text { Práticas Propostas }\end{array}$ & $\begin{array}{l}\text { Habilidades } \\
\text { Almejadas }\end{array}$ \\
\hline \multirow[t]{2}{*}{$\begin{array}{l}\rightarrow \square \text { Meio Ambiente: } \\
\text { - Biodiversidade } \\
\text { - Clima } \\
\text { - Biomas }\end{array}$} & $\begin{array}{l}\text { - Leitura em sala de aula } \\
\text { - Pesquisa em grupo }\end{array}$ & $\begin{array}{l}\text { - Preparar o aluno para o exercício da } \\
\text { cidadania por meio da socialização no } \\
\text { espaço escolar de conhecimentos, } \\
\text { competências, habilidades, valores e } \\
\text { atitudes, através de um processo de } \\
\text { interação de novas idéias e dos } \\
\text { conceitos aplicados. }\end{array}$ \\
\hline & $\begin{array}{l}\text { - Leitura em sala de aula } \\
\text { - Uso de recursos audiovisuais } \\
\text { - Palestras }\end{array}$ & $\begin{array}{l}\text { - Conhecer e estudar os conceitos de } \\
\text { meio ambiente e biodiversidade e os } \\
\text { aspectos do clima do País que são } \\
\text { componentes preponderantes do } \\
\text { desenvolvimento socioeconômico. }\end{array}$ \\
\hline \multirow[t]{6}{*}{$\begin{array}{l}\rightarrow \square \text { Meio Ambiente: } \\
\text { - Biodiversidade } \\
\text { - Clima } \\
\text { - Biomas }\end{array}$} & $\begin{array}{l}\text { - Laboratório } \\
\text { - Aulas práticas } \\
\text { - Visitas técnicas }\end{array}$ & $\begin{array}{l}\text { Identificar o aluno como parte } \\
\text { integrante da natureza e fazê-los sentir } \\
\text { afetivamente ligados a ela, percebendo } \\
\text { os processos pessoais como elementos } \\
\text { fundamentais para uma atuação criativa, } \\
\text { responsável e respeitosa em relação ao } \\
\text { meio ambiente. }\end{array}$ \\
\hline & $\begin{array}{l}\text { - Leitura e debates em sala de } \\
\text { aula } \\
\text { - Uso de recursos audiovisuais } \\
\text { - Palestras }\end{array}$ & $\begin{array}{l}\text { - Perceber, apreciar e valorizar a } \\
\text { diversidade natural e sociocultural, } \\
\text { adotando posturas de respeito aos } \\
\text { diferentes aspectos e formas do } \\
\text { patrimônio natural, étnico e cultural. }\end{array}$ \\
\hline & $\begin{array}{l}\text { - Aulas práticas } \\
\text { - Uso de internet }\end{array}$ & $\begin{array}{l}\text { Observar e analisar fatos e situações } \\
\text { do ponto de vista ambiental, } \\
\text { reconhecendo a necessidade e as } \\
\text { oportunidades de atuar de modo } \\
\text { propositivo, para garantir um meio } \\
\text { ambiente saudável e a boa qualidade de } \\
\text { vida. }\end{array}$ \\
\hline & - Pesquisa em grupo & $\begin{array}{l}\text { Aprender a viver juntos no Planeta } \\
\text { (País, região, cidade, bairro, } \\
\text { participando da vida em comunidade). }\end{array}$ \\
\hline & $\begin{array}{l}\text { - Leitura em individual } \\
\text { - Uso de internet }\end{array}$ & $\begin{array}{l}\text { - Conhecer os Biomas e o Clima do } \\
\text { País. Ainda sem considerações teóricas } \\
\text { sobre o turismo, apresentar bons } \\
\text { exemplos de práticas turísticas nos } \\
\text { biomas brasileiros. }\end{array}$ \\
\hline & $\begin{array}{l}\text { - Aulas práticas (de campo) } \\
\text { - Palestras }\end{array}$ & $\begin{array}{l}\text { - Palestras do IBRAM. Temas: } \\
\text { - Prevenção de Incêndios Florestais; } \\
\text { - Horta Escolar; e - Ecologia Alimentar, } \\
\text { com exemplos da culinária regional. }\end{array}$ \\
\hline $\begin{array}{l}\rightarrow \square \text { Sustentabilidade: } \\
\text { - Conceitos } \\
\text { - Formação ética } \\
\text { - Qualidade de vida }\end{array}$ & $\begin{array}{l}\text { - Leitura em sala de aula } \\
\text { - Pesquisa em grupo } \\
\text { Uso recursos audiovisuais e } \\
\text { internet }\end{array}$ & $\begin{array}{l}\text { - Conhecer e estudar os conceitos de } \\
\text { desenvolvimento sustentável e de } \\
\text { sustentabilidade e identificar os recursos } \\
\text { não renováveis. Explicar como a idéia } \\
\text { de sustentabilidade abrange vários } \\
\text { níveis de organização e pode ser } \\
\text { aplicada a diversas atividades humanas. } \\
\text { Um empreendimento sustentável deve } \\
\text { ser: ecologicamente correto; } \\
\text { economicamente viável; socialmente } \\
\text { justo e culturalmente aceito. }\end{array}$ \\
\hline
\end{tabular}




\begin{tabular}{|c|c|c|}
\hline \multicolumn{3}{|c|}{ CIÊNCIAS NATURAIS - VIDA E AMBIENTE (continuação $6^{\circ}$ ano/5ª série) } \\
\hline $\begin{array}{l}\text { Conteúdos } \\
\text { Previstos }\end{array}$ & $\begin{array}{l}\text { Técnicas/Ferramentas } \\
\text { Práticas Propostas }\end{array}$ & $\begin{array}{l}\text { Habilidades } \\
\text { Almejadas }\end{array}$ \\
\hline $\begin{array}{l}\rightarrow \square \text { Sustentabilidade: } \\
\text { - Conceitos } \\
\text { - Formação ética } \\
\text { - Qualidade de vida }\end{array}$ & $\begin{array}{l}\text { - Leitura em sala de aula } \\
\text { - Pesquisa em grupo } \\
\text { Uso recursos audiovisuais e } \\
\text { internet }\end{array}$ & $\begin{array}{l}\text { - Melhorar a qualidade da vida humana. } \\
\text { Esse é o verdadeiro objetivo do } \\
\text { desenvolvimento, ao qual o crescimento } \\
\text { econômico deve estar sujeito: permitir } \\
\text { que os seres humanos percebam o seu } \\
\text { potencial, obter autoconfiança e uma } \\
\text { vida plena de dignidade e satisfação. } \\
\text { Comportamentos ambientalmente } \\
\text { corretos deverão ser aprendidos na } \\
\text { prática do dia-a-dia na escola: gestos de } \\
\text { solidariedade e hábitos de higiene } \\
\text { pessoal. }\end{array}$ \\
\hline $\begin{array}{l}\rightarrow \square \text { Sustentabilidade: } \\
\text { - Conceitos } \\
\text { - Formação ética } \\
\text { - Qualidade de vida }\end{array}$ & $\begin{array}{l}\text { - Leitura em sala de aula } \\
\text { - Uso recursos audiovisuais } \\
\text { - Dinâmicas de grupo }\end{array}$ & $\begin{array}{l}\text { - Respeitar e cuidar da comunidade dos } \\
\text { seres vivos. Trata-se de um princípio } \\
\text { ético que "reflete o dever de nos } \\
\text { preocuparmos com as outras pessoas e } \\
\text { outras formas de vida, agora e no futuro } \\
\text { e da formação ética dos alunos. A } \\
\text { escola deve assumir-se como um } \\
\text { espaço de vivência e de discussão } \\
\text { desses referenciais, buscando construir } \\
\text { significados éticos e construtivos de toda } \\
\text { e qualquer ação de cidadania, } \\
\text { promovendo discussões sobre a } \\
\text { dignidade do ser humano, igualdade de } \\
\text { direitos e observância das leis. Os } \\
\text { jovens devem ser preparados para } \\
\text { conviver não só entre si e sua } \\
\text { comunidade, mas também com os } \\
\text { visitantes na localidade ou quando forem } \\
\text { visitantes em outros ambientes. }\end{array}$ \\
\hline \multirow[t]{3}{*}{$\begin{array}{l}\rightarrow \square \text { Turismo: } \\
\text { - Conceitos } \\
\text { - Patrimônio sócio } \\
\text { cultural } \\
\text { - Localização } \\
\text { geográfica }\end{array}$} & $\begin{array}{l}\text { - Leitura em sala de aula } \\
\text { - Pesquisa em grupo } \\
\text { - Uso recursos audiovisuais e } \\
\text { internet } \\
\text { - Excursões } \\
\text { - atividades extraclasse } 1\end{array}$ & $\begin{array}{l}\text { - Conhecer e estudar os conceitos de } \\
\text { turismo, turismo cívico, turismo rural e } \\
\text { ecoturismo, de modo a permitir que um } \\
\text { maior número de pessoas possa } \\
\text { participar de forma ativa e se } \\
\text { beneficiando da atividade turística } \\
\text { desenvolvida na localidade. A } \\
\text { Comunidade deve ser incentivada a } \\
\text { resgatar suas raízes, possibilitando } \\
\text { maior articulação entre seus membros } \\
\text { para que mostrem sua identidade } \\
\text { cultural aos turistas. Pelo turismo pode- } \\
\text { se sensibilizar a sociedade para } \\
\text { importância deste como instrumento de } \\
\text { desenvolvimento econômico, através da } \\
\text { geração de emprego. }\end{array}$ \\
\hline & $\begin{array}{l}\text { - Leitura em sala de aula } \\
\text { - Pesquisa individual }\end{array}$ & $\begin{array}{l}\text { - Valorizar o patrimônio sociocultural do } \\
\text { País. Essas ações proporcionam aos } \\
\text { turistas um olhar diferente que remete a } \\
\text { indagações e à compreensão do que } \\
\text { está sendo visitado, fazendo com que o } \\
\text { turista tenha uma relação mais profunda } \\
\text { com a comunidade. }\end{array}$ \\
\hline & - Pesquisa em grupo & $\begin{array}{l}\text { - Identificar a localização geográfica do } \\
\text { DF (paralelos e meridianos) e suas } \\
\text { regiões hidrográficas. }\end{array}$ \\
\hline
\end{tabular}




\begin{tabular}{|c|c|c|}
\hline \multicolumn{3}{|c|}{ CIĖNCIAS NATURAIS - VIDA E AMBIENTE (continuação 6ªno a $5^{2}$ série) } \\
\hline $\begin{array}{l}\text { Conteúdos } \\
\text { Previstos }\end{array}$ & $\begin{array}{l}\text { Técnicas/Ferramentas } \\
\text { Práticas Propostas }\end{array}$ & $\begin{array}{l}\text { Habilidades } \\
\text { Almejadas }\end{array}$ \\
\hline \multirow[t]{2}{*}{$\begin{array}{l}\rightarrow \square \text { Turismo: } \\
\text { - Conceitos } \\
\text { - Patrimônio sócio } \\
\text { cultural } \\
\text { - Localização } \\
\text { geográfica }\end{array}$} & $\begin{array}{l}\text { - Passeios e excursões } \\
\text { - Visitas técnicas }\end{array}$ & $\begin{array}{l}\text { - Realizar atividades voltadas para o } \\
\text { turismo cívico no DF: excursões aos } \\
\text { Palácios, incluindo o Catetinho (exceto a } \\
\text { Praça dos Três Poderes) e ao Zoológico } \\
\text { e seus aspectos relevantes ao turismo. }\end{array}$ \\
\hline & $\begin{array}{l}\text { - Aulas Práticas (de campo) } \\
\text { - Uso de internet } \\
\text { - Laboratório }\end{array}$ & $\begin{array}{l}\text { - Pesquisar e estimular a observação da } \\
\text { fauna e flora do cerrado e as riquezas } \\
\text { hidrográficas do Parque Nacional de } \\
\text { Brasília (Água Mineral). } \\
\text { - Conhecer os Parques Ecológicos das } \\
\text { RA's ligados às escolas - IBRAM. }\end{array}$ \\
\hline
\end{tabular}

\subsection{2 - $7^{\circ} \mathrm{Ano} / 6^{\mathrm{a}}$ Série}

\begin{tabular}{|c|c|c|}
\hline \multicolumn{3}{|c|}{ CIÊNCIAS NATURAIS - VIDA E AMBIENTE } \\
\hline $\begin{array}{l}\text { Conteúdos } \\
\text { Previstos }\end{array}$ & $\begin{array}{l}\text { Técnicas/Ferramentas } \\
\text { Práticas Propostas }\end{array}$ & $\begin{array}{l}\text { Habilidades } \\
\text { Almejadas }\end{array}$ \\
\hline \multirow[t]{4}{*}{$\begin{array}{l}\rightarrow \square \text { Meio Ambiente: } \\
\text { - Posturas } \\
\text { - Noções Básicas }\end{array}$} & $\begin{array}{l}\text { - Leitura em sala de aula } \\
\text { - Pesquisa em grupo }\end{array}$ & $\begin{array}{l}\text { - Adotar posturas na escola, em casa e } \\
\text { em sua comunidade que levem os } \\
\text { jovens à interações construtivas, justas } \\
\text { e ambientalmente sustentáveis. }\end{array}$ \\
\hline & $\begin{array}{l}\text { Uso recursos audiovisuais } \mathrm{e} \\
\text { internet. }\end{array}$ & $\begin{array}{l}\text { Compreender que os problemas } \\
\text { ambientais interferem na qualidade de } \\
\text { vida das pessoas, tanto local quanto } \\
\text { globalmente. }\end{array}$ \\
\hline & $\begin{array}{l}\text { - Leitura em sala de aula } \\
\text { - Pesquisa em grupo } \\
\text { - Palestras }\end{array}$ & $\begin{array}{l}\text { - Conhecer e compreender, de modo } \\
\text { integrado, as noções básicas } \\
\text { relacionadas ao meio ambiente e clima } \\
\text { do cerrado. }\end{array}$ \\
\hline & $\begin{array}{l}\text { - Aulas práticas (de campo) } \\
\text { - Palestras }\end{array}$ & $\begin{array}{l}\text { - Palestras do IBRAM. Temas: } \\
\text { - Resíduos Sólidos: A Responsabilidade } \\
\text { de Cada Um; } \\
\text { - Biodiversidade e Educação Ambiental } \\
\text { e o Distrito Federal. }\end{array}$ \\
\hline \multirow[t]{2}{*}{$\begin{array}{l}\rightarrow \square \text { Sustentabilidade: } \\
\text { - Estudo dos } \\
\text { recursos não- } \\
\text { renováveis } \\
\text { - Noções de } \\
\text { cidadania } \\
\text { - Detalhamento do } \\
\text { bioma cerrado }\end{array}$} & $\begin{array}{l}\text { - Laboratórios } \\
\text { Pesquisa em grupo } \\
\text { Uso recursos audiovisuais e } \\
\text { internet }\end{array}$ & $\begin{array}{l}\text { - Estudar os recursos não-renováveis } \\
\text { (critério de sustentabilidade). São } \\
\text { recursos como os minérios, petróleo, } \\
\text { gás, carvão mineral que podem ser } \\
\text { retirados com critérios de modo a reduzir } \\
\text { perdas e principalmente minimizar o } \\
\text { impacto ambiental. Devem ser usados } \\
\text { de modo a "ter sua vida prolongada } \\
\text { como, por exemplo, por meio de } \\
\text { reciclagem, pela utilização de menor } \\
\text { quantidade na obtenção de produtos, ou } \\
\text { pela substituição por outros recursos } \\
\text { renováveis, quando possível. }\end{array}$ \\
\hline & $\begin{array}{l}\text { - Leitura em sala de aula } \\
\text { - Pesquisa em grupo }\end{array}$ & $\begin{array}{l}\text { - Desenvolver posicionamento crítico } \\
\text { sobre a compreensão da cidadania. A } \\
\text { parcela de responsabilidade que cabe a } \\
\text { todos os cidadãos, inclusive ao jovem } \\
\text { estudante, quaanto ao meio em que vive. }\end{array}$ \\
\hline
\end{tabular}




\begin{tabular}{|c|c|c|}
\hline \multicolumn{3}{|c|}{ 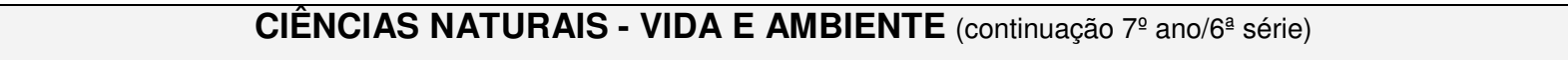 } \\
\hline $\begin{array}{l}\text { Conteúdos } \\
\text { Previstos }\end{array}$ & $\begin{array}{l}\text { Técnicas/Ferramentas } \\
\text { Práticas Propostas }\end{array}$ & $\begin{array}{l}\text { Habilidades } \\
\text { Almejadas }\end{array}$ \\
\hline $\begin{array}{l}\rightarrow \square \text { Sustentabilidade: } \\
\text { - Estudo dos } \\
\text { recursos não- } \\
\text { renováveis } \\
\text { - Noções de } \\
\text { cidadania } \\
\text { - Detalhamento do } \\
\text { bioma cerrado }\end{array}$ & $\begin{array}{l}\text { - Leitura em sala de aula } \\
\text { - Pesquisa em grupo e individual } \\
\text { - Laboratórios } \\
\text { - Palestras }\end{array}$ & $\begin{array}{l}\text { Aprofundar os conhecimentos e } \\
\text { aumentar as discussões sobre o bioma } \\
\text { cerrado e as características da } \\
\text { devastação da sua cobertura vegetal e } \\
\text { verificar os impactos negativos } \\
\text { causados por ações danosas à sua } \\
\text { diversidade biológica e cultural. }\end{array}$ \\
\hline \multirow[t]{5}{*}{$\begin{array}{l}\rightarrow \square \text { Turismo: } \\
\text { - Paisagens do } \\
\text { cerrado } \\
\text { - aspectos } \\
\text { - Turismo cívico e } \\
\text { rural - atividades e } \\
\text { programas }\end{array}$} & $\begin{array}{l}\text { - Leitura em sala de aula } \\
\text { - Pesquisa individual } \\
\text { - Uso de internet } \\
\text { - Excursões } \\
\text { - atividades extraclasse } 2\end{array}$ & $\begin{array}{l}\text { - Desenvolver e pesquisar as principais } \\
\text { atividades turísticas do DF que podem } \\
\text { contribuir para a divulgação das culturas } \\
\text { locais, ajudando na formação pessoal e } \\
\text { cidadã de seus membros, além de criar } \\
\text { um senso ético sobre as ações } \\
\text { pessoais, visto que as pessoas lutarão } \\
\text { por um desenvolvimento sustentável a } \\
\text { fim de manterem e fortalecerem sua } \\
\text { identidade e herança cultural através } \\
\text { das futuras gerações. }\end{array}$ \\
\hline & $\begin{array}{l}\text { - Pesquisa em grupo } \\
\text { - Visitas técnicas } \\
\text { - Aula expositiva }\end{array}$ & $\begin{array}{l}\text { - Estudar as características e aspectos } \\
\text { geomorfológicos das paisagens naturais } \\
\text { do cerrado (região de chapada, área de } \\
\text { dissecação intermediária e região } \\
\text { dissecada de vale). }\end{array}$ \\
\hline & $\begin{array}{l}\text { - Leitura em sala de aula } \\
\text { - Pesquisa individual } \\
\text { - Aula expositiva }\end{array}$ & $\begin{array}{l}\text { Conhecer o Programa Nacional de } \\
\text { Ecoturismo e do Turismo Rural: critérios } \\
\text { para atuação nas áreas protegidas. }\end{array}$ \\
\hline & $\begin{array}{l}\text { - Passeios e excursões } \\
\text { - Visitas técnicas }\end{array}$ & $\begin{array}{l}\text { - Realizar atividades voltadas para o } \\
\text { turismo cívico no Distrito Federal: } \\
\text { Excursão à Praça dos Três Poderes e } \\
\text { seus aspectos relevantes ao turismo. }\end{array}$ \\
\hline & $\begin{array}{l}\text { - Aulas Práticas (de campo) } \\
\text { - Uso de internet } \\
\text { - Laboratório } \\
\text { - Excursões } \\
\text { - atividades extraclasse } 2\end{array}$ & $\begin{array}{l}\text { - Pesquisar e estimular a observação da } \\
\text { fauna e flora do cerrado, as riquezas } \\
\text { hidrográficas da Estação Ecológica de } \\
\text { Águas Emendadas, as suas } \\
\text { características ambientais e os Hotéis } \\
\text { Fazendas RM ou Mestre D'armas ou } \\
\text { Águas Emendadas e particularidades. } \\
\text { Conhecer os Parques Ecológicos das } \\
\text { RA's ligados às escolas - IBRAM. }\end{array}$ \\
\hline
\end{tabular}

\subsection{3 - $8^{\circ} \mathrm{Ano} / 7^{\mathrm{a}}$ Série}

\begin{tabular}{|c|c|c|}
\hline \multicolumn{3}{|c|}{ CIÊNCIAS NATURAIS - VIDA E AMBIENTE } \\
\hline $\begin{array}{l}\text { Conteúdos } \\
\text { Previstos }\end{array}$ & $\begin{array}{l}\text { Técnicas/Ferramentas } \\
\text { Práticas Propostas }\end{array}$ & $\begin{array}{l}\text { Habilidades } \\
\text { Almejadas }\end{array}$ \\
\hline $\begin{array}{l}\rightarrow \square \text { Meio Ambiente: } \\
\text { - Condições } \\
\text { ambientais } \\
\text { - percepção }\end{array}$ & $\begin{array}{l}\text { - Leitura em sala de aula } \\
\text { - Pesquisa em grupo }\end{array}$ & $\begin{array}{l}\text { - Perceber, em diversos fenômenos } \\
\text { naturais, encadeamentos e relações de } \\
\text { causa/efeito que condicionam a vida no } \\
\text { espaço (geográfico) e no tempo } \\
\text { (histórico), utilizando essa percepção } \\
\text { para posicionar-se criticamente ante as } \\
\text { condições ambientais de seu meio. }\end{array}$ \\
\hline & $\begin{array}{l}\text { - Aulas práticas (de campo) } \\
\text { - Palestras }\end{array}$ & $\begin{array}{l}\text { - Lazer e Palestras do IBRAM. Temas: } \\
\text { - Uso e Ocupação do Solo; e } \\
\text { - Recursos Hídricos. }\end{array}$ \\
\hline
\end{tabular}




\begin{tabular}{|c|c|c|}
\hline \multicolumn{3}{|c|}{ CIÊNCIAS NATURAIS - VIDA E AMBIENTE (continuação $8^{\circ}$ ano/7ª série) } \\
\hline $\begin{array}{l}\text { Conteúdos } \\
\text { Previstos }\end{array}$ & $\begin{array}{l}\text { Técnicas/Ferramentas } \\
\text { Práticas Propostas }\end{array}$ & $\begin{array}{l}\text { Habilidades } \\
\text { Almejadas }\end{array}$ \\
\hline \multirow[t]{4}{*}{$\begin{array}{l}\rightarrow \square \text { Sustentabilidade: } \\
\text { - Atitudes, práticas e } \\
\text { comportamentos } \\
\text { - Alternativas de } \\
\text { desenvolvimento } \\
\text { sustentável } \\
\text { - Biomas } \\
\text { - características e } \\
\text { distinções }\end{array}$} & $\begin{array}{l}\text { - Leitura e debate em sala de } \\
\text { aula }\end{array}$ & $\begin{array}{l}\text { - Modificar atitudes e práticas pessoais. } \\
\text { Para adotar a ética de se viver } \\
\text { sustentavelmente, as pessoas devem } \\
\text { ser motivadas a reexaminarem os seus } \\
\text { valores. A educação para o turismo, } \\
\text { dentro dos princípios da sustentabilidade } \\
\text { ambiental mostra-se de extrema valia } \\
\text { para o próprio desenvolvimento } \\
\text { sustentável das comunidades. Pode, } \\
\text { portanto, ser muito útil, mesmo que não } \\
\text { tenha a comunidade perfil para o } \\
\text { turismo, para que seus jovens aprendam } \\
\text { a comportar-se como visitantes ou } \\
\text { turistas, com comportamentos } \\
\text { adequados ambientalmente, de modo a } \\
\text { estarem sempre contribuindo para a } \\
\text { sustentabilidade dos locais que } \\
\text { convivam, seja como visitantes, turistas } \\
\text { ou receptores de turismo. }\end{array}$ \\
\hline & $\begin{array}{l}\text { - Leitura e debate em sala de } \\
\text { aula }\end{array}$ & $\begin{array}{l}\text { - Alterar comportamentos inadequados. } \\
\text { A sociedade deve promover atitudes que } \\
\text { apóiem a nova ética e desfavoreçam } \\
\text { aqueles que não se coadunem com o } \\
\text { modo de vida sustentável. }\end{array}$ \\
\hline & $\begin{array}{l}\text { - Pesquisa em grupo } \\
\text { - Seminários }\end{array}$ & $\begin{array}{l}\text { Desenvolver alternativas de } \\
\text { desenvolvimento sustentável, aspectos } \\
\text { da contaminação das águas, melhoria } \\
\text { do meio ambiente e qualidade de vida. }\end{array}$ \\
\hline & - Pesquisa em grupo & $\begin{array}{l}\text { - Verificar as principais características e } \\
\text { distinções entre os Biomas Brasileiros. }\end{array}$ \\
\hline \multirow{4}{*}{$\begin{array}{l}\rightarrow \square \text { Turismo: } \\
\text { - Ecoturismo } \\
\text { - tipos } \\
\text { - Turismo rural } \\
\text { - conceitos, origem } \\
\text { e ocupação } \\
\text { desordenada }\end{array}$} & $\begin{array}{l}\text { - Aulas Práticas (de campo) } \\
\text { - Uso de internet } \\
\text { - Laboratório }\end{array}$ & $\begin{array}{l}\text { - Conhecer os principais tipos do } \\
\text { ecoturismo em Brasília (observação de } \\
\text { fauna, flora, riquezas hídricas e aves, } \\
\text { espeologia) e suas particularidades. }\end{array}$ \\
\hline & - Pesquisa individual & $\begin{array}{l}\text { - Estudar e conceituar o Turismo Rural } \\
\text { e a ocupação desordenada da área } \\
\text { urbana. }\end{array}$ \\
\hline & $\begin{array}{l}\text { - Passeios e excursões } \\
\text { - Visitas técnicas } \\
\text { - Excursões } \\
\text { - atividades extraclasse } 3\end{array}$ & $\begin{array}{l}\text { - Conhecer as principais atividades e } \\
\text { programas do Turismo Rural no Distrito } \\
\text { Federal - Sua história, origem e } \\
\text { aspectos gerais de exploração e } \\
\text { conservação. }\end{array}$ \\
\hline & $\begin{array}{l}\text { - Aulas Práticas (de campo) } \\
\text { - Uso de internet } \\
\text { - Laboratório }\end{array}$ & $\begin{array}{l}\text { - Pesquisar e estimular a observação de } \\
\text { fauna, flora, aves e riquezas hídricas da } \\
\text { região de Mumunhas ou Poço Azul e as } \\
\text { suas características ambientais. }\end{array}$ \\
\hline
\end{tabular}




\subsection{4 - $9^{\circ}$ Ano $/ 8^{a}$ Série}

\begin{tabular}{|c|c|c|}
\hline \multicolumn{3}{|c|}{ CIÊNCIAS NATURAIS - VIDA E AMBIENTE } \\
\hline $\begin{array}{l}\text { Conteúdos } \\
\text { Previstos }\end{array}$ & $\begin{array}{l}\text { Técnicas/Ferramentas } \\
\text { Práticas Propostas }\end{array}$ & $\begin{array}{l}\text { Habilidades } \\
\text { Almejadas }\end{array}$ \\
\hline $\begin{array}{l}\rightarrow \square \text { Meio Ambiente: } \\
\text { - Manejos dos } \\
\text { recursos naturais } \\
\text { - Plano Plurianual } \\
\text { - Ministério do Meio } \\
\text { Ambiente } \\
\text { - Agenda } 21 \\
\text { Brasileira e Local } \\
\text { - Agenda Escolar }\end{array}$ & $\begin{array}{l}\text { - Aulas práticas (de campo) } \\
\text { - Palestras }\end{array}$ & $\begin{array}{l}\text { - Palestras do IBRAM. Temas: } \\
\text { - O Desenvolvimento Sustentável e o } \\
\text { Cidadão; } \\
\text { - Agroecologia; e } \\
\text { - Agenda } 21 \text { Local, Escolar e Regional. }\end{array}$ \\
\hline \multirow[t]{5}{*}{$\begin{array}{l}\rightarrow \square \text { Sustentabilidade: } \\
\text { - Educação } \\
\text { Ambiental } \\
\text { - atitudes e } \\
\text { comportamentos } \\
\text { - Comunidades } \\
\text { - atividades } \\
\text { produtivas } \\
\text { - APA's e desgastes } \\
\text { ambientais }\end{array}$} & $\begin{array}{l}\text { - Leitura em sala de aula } \\
\text { - Pesquisa em grupo }\end{array}$ & $\begin{array}{l}\text { Aprofundar o conhecimento de } \\
\text { Educação Ambiental para desenvolver } \\
\text { hábitos, atitudes e comportamentos que } \\
\text { propiciem a formação, no aluno, de uma } \\
\text { cultura eminentemente ativa na defesa } \\
\text { de um meio ambiente saudável e do uso } \\
\text { racional dos recursos naturais não- } \\
\text { renováveis. As comunidades locais } \\
\text { devem ter a capacidade de repensar seu } \\
\text { processo de desenvolvimento, corrigindo } \\
\text { distorções e propondo inovações que } \\
\text { garantam o desenvolvimento, sem } \\
\text { comprometer, irremediavelmente, as } \\
\text { condições ambientais. }\end{array}$ \\
\hline & $\begin{array}{l}\text { - Pesquisa em grupo } \\
\text { - Visitas técnicas }\end{array}$ & $\begin{array}{l}\text { - Permitir que as comunidades cuidem } \\
\text { de seu próprio ambiente (meio para se } \\
\text { chegar à sustentabilidade). E nas } \\
\text { comunidades que os indivíduos } \\
\text { desenvolvem a maioria das atividades } \\
\text { produtivas e criativas. E constituem o } \\
\text { meio mais acessível para a } \\
\text { manifestação de opiniões e tomada de } \\
\text { decisões sobre iniciativas e situações } \\
\text { que as afetam. }\end{array}$ \\
\hline & $\begin{array}{l}\text { - Leitura e debates em sala de } \\
\text { aula }\end{array}$ & $\begin{array}{l}\text { Enfocar que os desgastes ambientais } \\
\text { interligam-se uns aos outros e de que } \\
\text { problemas econômicos e ambientais } \\
\text { estão relacionados a muitos fatores } \\
\text { políticos e sociais e que a } \\
\text { compatibilização entre a utilização dos } \\
\text { recursos naturais e a conservação do } \\
\text { meio ambiente deve ser um } \\
\text { compromisso da humanidade. }\end{array}$ \\
\hline & $\begin{array}{l}\text { - Seminários e feiras } \\
\text { Uso recursos audiovisuais e } \\
\text { internet }\end{array}$ & $\begin{array}{l}\text { Conscientizar os alunos quanto à } \\
\text { importância da preservação da } \\
\text { qualidade do meio ambiente e proteção } \\
\text { das APA's (desmatamento, erosão e } \\
\text { agropecuária). }\end{array}$ \\
\hline & $\begin{array}{l}\text { - Pesquisa em Grupo } \\
\text { Uso recursos audiovisuais e } \\
\text { internet }\end{array}$ & $\begin{array}{l}\text { - Aprofundar os conhecimentos e as } \\
\text { diferenças sobre proteção, conservação, } \\
\text { preservação, recuperação e degradação } \\
\text { do meio ambiente e as definições de } \\
\text { "bioma" e "ecossistemas". Aplicá-las à } \\
\text { localidade. }\end{array}$ \\
\hline
\end{tabular}




\begin{tabular}{|c|c|c|}
\hline \multicolumn{3}{|c|}{ CIÊNCIAS NATURAIS - VIDA E AMBIENTE (continuação $9^{\circ}$ ano/ $8^{a}$ série) } \\
\hline $\begin{array}{l}\text { Conteúdos } \\
\text { Previstos }\end{array}$ & $\begin{array}{l}\text { Técnicas/Ferramentas } \\
\text { Práticas Propostas }\end{array}$ & $\begin{array}{l}\text { Habilidades } \\
\text { Almejadas }\end{array}$ \\
\hline \multirow[t]{3}{*}{$\rightarrow \square$ Turismo: } & $\begin{array}{l}\text { - Passeios e excursões } \\
\text { - Visitas técnicas }\end{array}$ & $\begin{array}{l}\text { - Pesquisar e estimular a observação de } \\
\text { fauna, flora, aves e riquezas hídricas e } \\
\text { exploração das cavernas de Corumbá } \\
\text { ou Planaltina de Goiás e suas } \\
\text { particularidades. }\end{array}$ \\
\hline & $\begin{array}{l}\text { - Aulas Práticas (de campo) } \\
\text { - Uso de internet } \\
\text { - Laboratório } \\
\text { - Excursões } \\
\text { - atividades extraclasse } 4\end{array}$ & $\begin{array}{l}\text { - Pesquisar e estimular a observação de } \\
\text { fauna, flora, aves e riquezas hídricas da } \\
\text { região de Velha ou Tororó e as suas } \\
\text { características ambientais. } \\
\text { - Conhecer os Parques Ecológicos das } \\
\text { RA's ligados às escolas - IBRAM. }\end{array}$ \\
\hline & $\begin{array}{l}\text { - Feiras } \\
\text { - Excursões } \\
\text { - atividades extraclasse } 4\end{array}$ & $\begin{array}{l}\text { - Participar das feiras da Embrapa e de } \\
\text { tecnologia da escola. }\end{array}$ \\
\hline
\end{tabular}




\section{CONSIDERAÇÕES FINAIS}

O turismo é um importante instrumento de desenvolvimento econômico das regiões já que gera empregos e vem ganhando maior destaque junto à sociedade, pois é uma das principais fontes de lazer na atualidade, o que exige maior planejamento para a exploração sustentável dessa atividade, do seu meio ambiente e da sua cultura local, sendo necessária melhor preparação dos jovens, desde o início de sua formação, para que ele possa participar com maior grau de comprometimento do planejamento e da execução do plano turístico da localidade.

Os alunos deverão aprender a conviver com esta realidade e serem preparados para receberem os turistas ou comportarem adequadamente quando forem turistas, pois buscar inserir o turismo sustentável no ensino escolar é essencial para garantir o alcance desses requisitos.

Para tanto, mostrou-se a importância em respeitar os princípios da Educação Ambiental já que toda ação destrutiva que parte de qualquer lugar tem reflexo em todos os outros lugares do planeta, demonstrado que é correta a decisão em tornar a EA uma adoção obrigatória em todos os níveis de ensino como caráter interdisciplinar.

Quanto a preparação para o ensino da EA, os docentes deverão desencadear ações, juntamente com as instituições educacionais, visando desenvolver hábitos, atitudes e comportamentos proativos na defesa de um meio ambiente saudável e do uso politicamente correto dos recursos naturais, visando transformar essas teorias em práticas dinâmicas de ensino conectadas às realidades locais, principalmente no caso do cerrado, o mais antigos dos biomas.

Sobre o cerrado, percebeu-se que as atividades particularidades específicas relacionadas à sua flora e fauna são renegadas ao segundo plano e poderiam ser desenvolvidas de modo a receber maiores interesses dos alunos. Mostrou-se a necessidade de estudá-lo em seus aspectos de proteção, preservação, conservação, recuperação, degradação e a relação com a sustentabilidade de seu meio quando explorado para as atividades de turismo.

Em relação aos PCN's, identificou-se os principais objetivos, com destaque para o esforço para que se conheça as características fundamentais do Brasil, suas dimensões sociais, materiais e culturais, buscando a construção progressiva da noção de identidade e pertinência ao País, mas que, na pratica, tem-se mostrado 
ainda longe dos ideais no sentido da sustentabilidade e do turismo responsável.

Concluiu-se que na estrutura do PCN o Tema Transversal "Meio Ambiente" é o ideal para trabalhar o subitem "Turismo Sustentável". Propicia municiar os alunos de conceitos de sustentabilidade e turismo voltados para as regiões que são afetadas pela exploração do seu meio ambiente natural, já que a LDB permite, em seu Artigo 26, que, embora os currículos do ensino fundamental tenham bases nacionais, esses deverão ser complementados pelas características regionais e locais da sociedade, cultura, economia e clientela, tendo como princípios:

- A percepção das relações dos fatores vivos entre si e com os fatores não-vivos;

- A percepção dos ciclos e fluxos na natureza;

- A percepção da necessidade de proteção do ambiente;

- A aquisição da noção das características principais dos ecossistemas brasileiros;

- A compreensão de um exemplo de desequilíbrio ambiental e de suas conseqüências;

- A compreensão das relações de interdependência alimentar nos ecossistemas;

- A compreensão do papel da reciclagem no funcionamento da natureza;

- A identificação e valoração de intervenções humanas no ambiente; e

- O reconhecimento da importância do conhecimento do universo para uma melhor compreensão de nossa posição no espaço e de respeito ao ambiente em que vivemos.

Desta forma, estudou-se as Orientações Curriculares do Ensino Fundamental do DF porque: norteia o processo de ensino e aprendizagem na capital; tem como objetivo básico preparar o aluno para o exercício da cidadania, por meio da socialização no espaço escolar; responde às solicitações dos educadores na busca de referenciais para organizar, acompanhar e implementar os projetos políticospedagógicos das escolas e que são complementados pelos planos dos professores.

Quanto aos docentes, esses deveriam priorizar a realidade local, mas pecam por valorizarem outras regiões em detrimento ao bioma cerrado e ao turismo nele realizado, que deve ser sustentável. Provavelmente isso ocorra devido ao aspecto da região e de seus animais e plantas serem "menos exóticos". Embora o bioma tenha recebido nos últimos anos significativa atenção dos pesquisadores, é questionável se estes novos conhecimentos tenham sido difundidos adequadamente à população leiga, pois não está incorporado às políticas de desenvolvimento da região. 
Ainda em relação ao professor, cabe a ressalva sobre a questão da sua baixa valorização profissional, seja salarial ou quanto a formação adequada para elaboração de um bom plano de estudo, já que é através desses profissionais que são formados cidadãos que num futuro próximo poderão promover as mudanças importantes que são necessárias a um mundo melhor, do ponto de vista social e ambiental.

Diante disso, o estudo constatou a inexistência de uma série de tópicos e importantes assuntos relacionados ao meio ambiente, sustentabilidade e turismo da região. Sugeriu-se o incremento de novas orientações curriculares para as séries finais do ensino fundamental, visando priorizar a educação ambiental e o turismo sustentável na localidade, são eles:

- O estudo do bioma cerrado e as características do DF, o turismo cívico de Brasília e suas principais atrações (igrejas, santuários, parques, palácios e monumentos);

- O ecoturismo no cerrado e suas variáveis (flutuação, observação da fauna, flora, aves, riquezas naturais e espeologia), além da visitação aos diversos parques ecológicos; e

- O turismo rural na região do entorno.

Nesse sentido e levando-se em consideração as particularidades e dificuldades de cada RA do Distrito Federal, além da preocupação e respeito às suas especificidades, a proposta foi de apresentar conteúdos e procedimentos para - Ensino Fundamental das Ciências Naturais no Tema Transversal do Meio Ambiente, cuja principal função é contribuir para a formação de cidadãos conscientes, aptos a decidirem e a atuarem na realidade socioambiental de modo comprometido com a vida, com o bem-estar de cada um e da sociedade local e global. Para tal, são necessários mais do que informações e conceitos, que a escola se proponha a trabalhar com atitudes, com formação de valores, com ensino e a aprendizagem de habilidade e procedimentos, já que comportamentos ambientalmente corretos devem ser aprendidos na prática do dia-a-dia da escola. Foram estas as metas do estudo.

Para tal, este estudo também propôs metodologias para abordagem dos temas, baseando-se em:

- Nas aulas de laboratórios e aulas práticas (de campo) e visitas técnicas, pois há dados que demonstram que os alunos gostam desse tipo de aula e se sentem motivados já que o assunto está ligado ao meio ambiente; 
- Nos passeios e excursões, que são instrumentos que tendem a associar teoria e prática;

- Na leitura em sala de aula, para entender e conhecer, para sonhar, viajar na imaginação, por prazer ou curiosidade;

- Nas pesquisas em grupo e individual, que trazem como contribuição o questionamento reconstrutivo;

- No uso de Recursos Audiovisuais e Internet, porque é um poderoso recurso de aprendizagem, mas que deve ser monitorado; e

- Nos seminários e feiras, que contribuem para completar a função da escola na sua missão de difundir e proporcionar aos indivíduos a possibilidade de se apropriar de uma cultura tecnológica e científica, contribuindo também para o aperfeiçoamento da autonomia do professor na sua prática pedagógica.

Nesta pesquisa, propôs-se a revisão do estudo das relações entre o meio ambiente e a sustentabilidade do turismo no Distrito Federal e sua aplicação no Ensino Fundamental, Séries e Anos Finais, como Subtema do Tema Transversal "Meio Ambiente" nas Orientações Curriculares do Ensino Fundamental do DF, pois foi observado, que esses assuntos poderiam receber melhor atenção, principalmente em relação à Educação Ambiental, ao bioma cerrado, com aplicações também para o turismo cívico, o ecoturismo e o turismo rural de um modo geral e particularmente de Brasília.

Como resultado, a futura aplicação poderá ser estimulada, de modo descentralizado pela Secretaria de Educação, a partir das particularidades de cada Região Administrativa, suas necessidades e disponibilidades, tanto para a rede pública, quanto para a rede particular, principalmente devido à expansão demográfica dessas cidades, inclusive com reflexos na Capital da República.

Em face às observações expostas ao longo do estudo, espera-se que, com a participação dos jovens e apoio dos professores neste processo será possível cobrar da sociedade uma maior participação para a sustentabilidade do meio em que vivem. É fundamental a preparação deles como futuros cidadãos, sejam como turistas ou como moradores das regiões visitadas, ou ainda, como futuros profissionais. Objetiva-se também atender às necessidades dos turistas de hoje, e das regiões receptoras, sem deixar de cuidar da integridade cultural, dos processos ecológicos, da diversidade biológica e da manutenção da vida humana. Ou seja, devendo cuidar da qualidade de vida de um modo geral, já que as crianças e os 
jovens são promotores fundamentais para as mudanças de comportamento dessas comunidades, através do exercício da cidadania que tem início com a correta socialização no espaço escolar.

Finalmente, espera-se que 0 aluno acabe rejeitando as concepções equivocadas que têm sobre o meio ambiente e o desenvolvimento do turismo sustentável, especialmente no cerrado, estudado de forma simplista, e tenha a oportunidade de reformular-se, vivenciando várias situações-problema. O que se quer é promover a migração de suas idéias do senso comum para o conhecimento científico ambientalmente correto e humanitário. Como vimos, os estragos que causamos à biosfera podem impedir a sobrevivência do ser humano e isso deve ser evitado para que haja a sobrevivência sustentável do homem na terra. 


\section{REFERÊNCIAS}

ANDRADE Eliane; ESTEVES Luiz; NETO Miguel. Programa Ciência em Foco: Diagnóstico do Impacto Ambiental. Secretaria de Estado da Educação do Distrito Federal - SEDF. Rede de Informação Tecnológica Latino-Americana RITLA. Universidade Federal do Estado do Rio de Janeiro - UNIRIO. 1 Ed. Brasília, 2009.

ANDRADE, José Vicente de. Turismo - Fundamentos e dimensões. 6 ed. São Paulo: Ática, 2004.

BARRETTO, Margarida. Turismo e Legado Cultural. 2 ed. Campinas: Papirus, 2004.

BENI, Mário Carlos. Análise Estrutural do Turismo. 10 ed. São Paulo: Senac, 2004.

BIZERRIL, Marcelo Ximenez Aguiar. O Cerrado e a Escola: Uma análise da educação ambiental no ensino fundamental do Distrito Federal. UnB, Departamento de Ecologia, Pós-Graduação em Ecologia, Brasília: 2001.

BRASIL. Constituição (1988). Capítulo VI Do Meio Ambiente art. 225. , §’s 1ํ, I , III e VI. Direito de todos ao meio ambiente equilibrado. e $2^{\circ}$. Obrigação de recuperar o meio ambiente.

BRASIL. Ministério da Educação - Lei 9.394/1996 - Lei de Diretrizes e Bases da Educação Nacional - LDB de 20 de dezembro de 1996. Art. 5 e 32‥ Disponível em http://portal.mec.gov.br. Acesso em 19 fev 2009.

BRASIL. Ministério da Educação - Lei 6.938 de 31 de agosto de 1981. Dispõe sobre a Política Nacional do Meio Ambiente. Diário Oficial República Federativa do Brasil, Poder Executivo, Brasília, DF 2 set. 1981

BRASIL. Governo do Distrito Federal - Instituto do Meio Ambiente e dos Recursos Hídricos do Distrito Federal - Brasília Ambiental (IBRAM) - Disponível em http://www.ibram.df.gov.br - acesso em 01 jun. 2009. 
BRASIL. Governo do Distrito Federal - Secretaria de Estado de Educação do Distrito Federal. Currículo de Educação Básica das Escolas Públicas. 1993.

BRASIL. Governo do Distrito Federal - Secretaria de Estado de Educação Orientações Curriculares do Ensino Fundamental, Séries e Anos Finais/Secretaria de Educação/GDF 2009 - Disponível em http://www.se.df.gov.br acesso em 01 mar. 2009.

BRASIL. Ministério da Educação - Parâmetros Curriculares Nacionais - PCN's: terceiro e quarto ciclos do ensino fundamental: introdução aos parâmetros curriculares nacionais/Secretaria de Educação Fundamental. - Brasília: MEC/SEF, 1998. 174 p. 1. Parâmetros curriculares nacionais. 2. Ensino de quinta a oitava séries. I. Título. B823p Brasil. Secretaria de Educação Fundamental.

BRASIL. Ministério do Turismo: Destinos e Roteiros - Distrito Federal. Brasília. Disponível em: http://www.braziltour.com/site/br/destinos_roteiros/. Acesso em 24 mar. 2009.

BRASILEIRO, lara Lúcia Gomes. Texto Fundamentos da Sustentabilidade/Módulo 6 CET/UnB, Brasília: 2008.

BUENO, Assessora Pedagógica da OAK Educação e Meio Ambiente em 10/01/2002 - Disponível em: www.midiamix.com.br. Acesso em: 25 abr. 2009.

BUENO, Silviera. Minidicionário da Língua Portuguesa, Ed. rev e atual. - São Paulo: Editora FTD, 2000.

CHIOZZINI, Daniel. Turismo e educação patrimonial mais próximos. Revista Eletrônica do IPHAN. Disponível em http://www.revista.iphan.gov.br/materia. Acesso em: 20 Fev. 2009.

COSTA, Cléria Botelho da. Responsabilidade Social, Turismo e Sustentabilidade Sociocultural/Módulo 3 CET/UnB, Brasília: 2008. 
CYSNEIROS, Paulo G. (1999). Resenha Crítica: S.M. Papert. A Máquina das Crianças: Repensando a Escola na Era da Informática. Porto Alegre, RS, Artes Médicas. Rev Bras. de Informática na Educação (UFSC, Depto de Informática), n.6.

DIAS, Reinaldo. Introdução ao turismo. São Paulo: Atlas, 2005.

DIAS, Reinaldo. Sociologia do Turismo. 2 ed. São Paulo: Atlas, 2003.

FARIA, Dóris Santos de, CARNEIRO Kátia Saraiva. Sustentabilidade ecológica no turismo. Brasília: Ed. Universidade de Brasília, 2001.

FARIA, Dóris Santos de, Educação Ambiental e Científico-Tecnológica/EAC\&T. Série "O Professor em Construção" Vol 1. Editora UnB,BRASíLIA-DF: Universidade de Brasília, 1997. v.1. 118 p.

FRANÇA, Lisa Goyas. Da Cidade Real à Cidade Ideal. Brasília: oำ, p.09, 2006.

GODOY, Jane - DF tem melhor Índice de Desenvolvimento Humano do país, Correio Braziliense, Brasília, 16 set 2008, Cidade, pag 5.

IGNARA, Luiz Renato. Fundamentos do turismo. 3 ed. São Paulo: Pioneira Thomson Learning, 2001.

KRIPPENDORF, Jost. Sociologia do turismo: para uma nova compreensão do lazer e das viagens. 3 ed. São Paulo: Aleph, 2003.

LICKORISH, Leonardo J. JENKINS, Carson L. Introdução ao turismo. 2 ed. São Paulo: Campus, 2000.

MENEZES, Ebenezer de. Artigo "Professores de mãos dadas com o meio ambiente". Agência EducaBrasil entrevista a Professora Tânia Regina Moura

MIRANDA, Evaristo Eduardo de. O Descobrimento da Biodiversidade. 1 ed. Loyola 2004.

MONTENEGRO, Ruy. Turismo rural e ecoturismo no Distrito Federal. Revista múltipla - União Pioneira de Integração Social. Faculdades Integradas v.7, n.11. Brasília: 2001. 
NOVAES, Washington. Agenda 21: um novo modelo de civilização, IN TRIGUEIRO, Carlos. Meio Ambiente no Século 21. Rio de Janeiro. Ed: Sextante, 2003.

SARDINHA, Flávio José. Turismo rural e sustentabilidade no Distrito Federal: propriedades Fazenda Velha e Trem da Serra. Trabalho Final de Curso (especialização) - Gestão Ambiental - Universidade Estadual de Goiás, Unidade de Formosa: 2006.

SCUARCIALUPI Lu - DIRETRIZES - Por dentro da Lei de Diretrizes e Bases, O que é a Lei de Diretrizes e Bases, quais os principais ganhos para os cidadãos e a história até sua aprovação em 1996, 26/08/2008 - disponível em http://educarparacrescer.abril.com.br/politica-publica/lei-diretrizes-bases-9321.shtml. Acesso em 05 mai. 2009.

SERVIÇO BRASILEIRO DE APOIO ÀS MICRO E PEQUENAS EMPRESAS (SEBRAE). Disponível em http://sebrae.com.br. Acesso em: 20 fev.2009.

TRIGO, Luiz Gonzaga Godoi. A sociedade pós-industrial e o profissional em turismo. 6 ed. Campinas, SP: Papirus, 2002. 